Portland State University

PDXScholar

1979

\title{
The non-career ambassador in America's diplomacy : case study, Frederic Mosley Sackett, Ambassador to Germany, January, 1930-March, 1933
}

Stephen A. Nicholls

Portland State University

Follow this and additional works at: https://pdxscholar.library.pdx.edu/open_access_etds

Part of the Diplomatic History Commons, and the United States History Commons Let us know how access to this document benefits you.

\section{Recommended Citation}

Nicholls, Stephen A., "The non-career ambassador in America's diplomacy : case study, Frederic Mosley Sackett, Ambassador to Germany, January, 1930-March, 1933" (1979). Dissertations and Theses. Paper 2927.

https://doi.org/10.15760/etd.2926

This Thesis is brought to you for free and open access. It has been accepted for inclusion in Dissertations and Theses by an authorized administrator of PDXScholar. Please contact us if we can make this document more accessible: pdxscholar@pdx.edu. 
AN ABSTRACT OF THE THESIS OF Stephen A. Nicholls for the Master of Arts in History presented 26 January 1979.

Title: The Non-Career Ambassador in America's Diplomacy. Case Study: Frederic Mosley Sackett, Ambassador to Germany, January, 1930 - March, 1933.

APPROVED BY MEMBERS OF THE THESIS COMMITTEE:

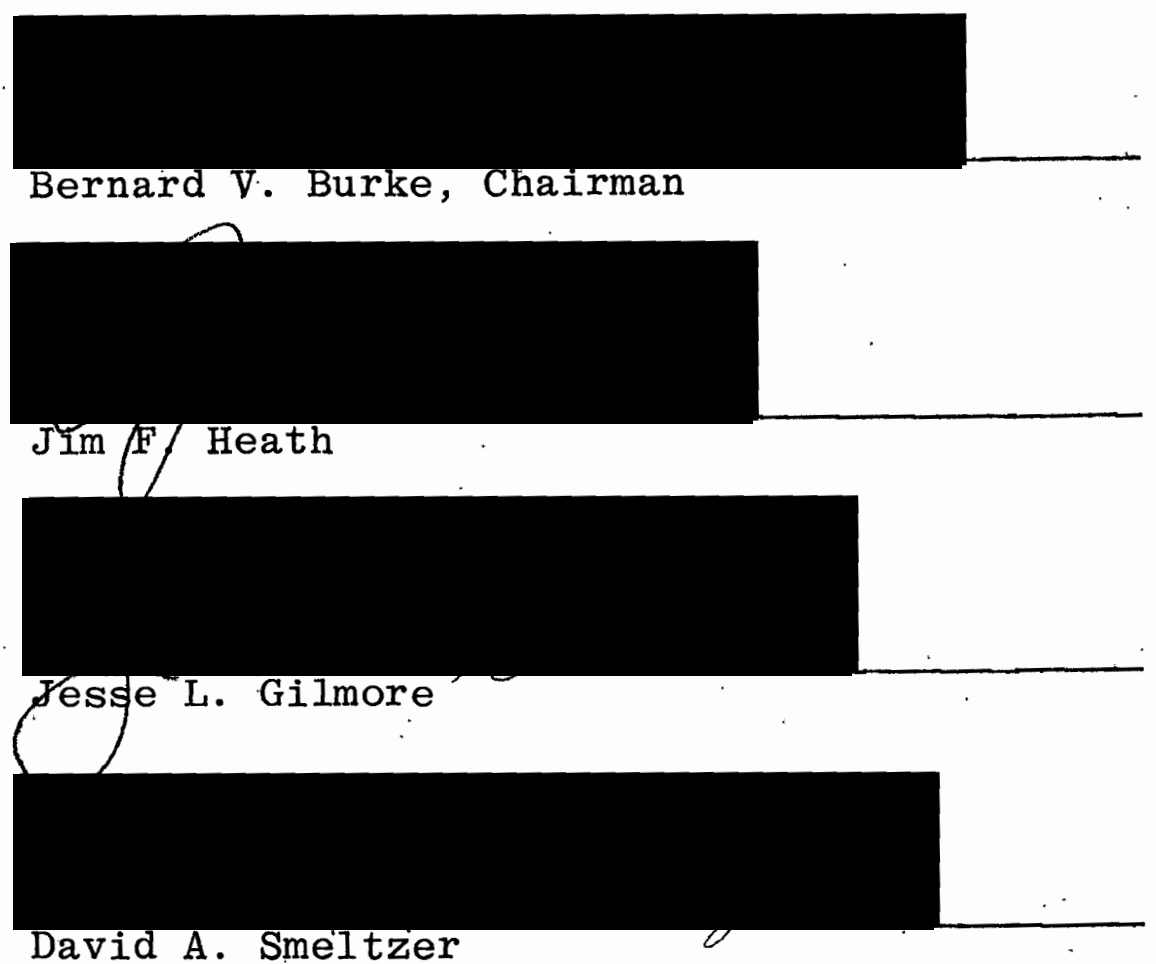

This thesis explores a continuous problem facing those who conduct American diplomatic affairs: the appointment of amateurs, with no previous experience in diplomacy, as ambassadors representing the United States abroad. This study 
contends that the noncareer, nonprofessional appointment is neither necessarily a bad thing nor should it be considered undesirable, given the American system of conducting its foreign affairs. On the contrary this thesis argues that the amateur ambassador can effectively serve to enhance the needs of American foreign policy without having the same professional training accorded to the career foreign service officer.

The historical literature about the merits of appointing professional career men from the American foreign service versus the practice of selecting amateurs from the political spoils system is reviewed. Arguments from both sides of the debate, as well as several middle-of-the-road positions, are examined. From these a number of questions are extracted for use in the assessment of an amateur diplomat's performance.

A case study of an amateur diplomat chosen from the political spoils system by President Herbert Hoover forms the core of this thesis. Clear in his commitment to the advancement of the career diplomacy for the United States, Hoover nevertheless found room for political spoilsmen. His conduct of foreign affairs during the time of the Great Depression in the early 1930s, especially with regard to Europe, sets the background for a detailed study of one such compromise of the ideal regarding professional appointments which drew criticism not only from the contemporaries at the 
time but from historians as well.

At the time of Frederic Sackett's appointment, as Ambassador to Germany, he was an incumbent United States Senator from Kentucky deemed by that state's Republican party to be a political liability and not capable of winning re-election to the senate in 1930. Sackett was also a wealthy businessman (he owned several coal mines in Kentucky), a lawyer, and a long-time political supporter of Herbert Hoover. Mindful of the domestic political considerations, however, Hoover appointed Sackett as Ambassador to Germany during the critical period of 1930-33 when Adolf Hitler pushed for the control of the Reich. At that time, most of America's relations with Germany were in the sphere of business/economics and, as a successful businessman himself, Sackett superficially seemed suited for the job. Yet, having no real experience in the workings of American diplomacy, Sackett fits into many of the stereotypes commonly applied to the amateur appointee from the spoils system.

The central question confronted in this thesis is, given the circumstances of his appointment, was sackett the amateur successful as an American ambassador?

Utilizing primary source materials, including memoirs, personal papers, newspaper articles and official government documents, plus secondary accounts of the diplomacy of the period, the events and actions surrounding Sackett's experience in Germany are explored. Many historians dealing with 
this period of American relations with Europe have been critical of Sackett's role in the events of the time and his influence upon them. Evaluations of his record are frequent1y tied to the harsh judgement that, since America's foreign policy toward Europe failed, his ambassadorship was also a failure. However, if Sackett's performance as ambassador is considered in light of the assessment of his contemporaries, emphasizing his abilities as a nonprofessional diplomat as well as his role in the delicate events occurring in the Weimar Republic at the time, his tenure must be rated as successful. 


\title{
THE NON-CAREER AMBASSADOR \\ IN AMERICA'S DIPLOMACY
}

\author{
Case Study: Frederic Mosley Sackett \\ Ambassador to Germany, \\ January, 1930 - March, 1933 \\ by \\ STEPHEN A. NICHOLLS
}

A thesis submitted in partial fulfillment of the requirements for the degree of

\author{
MASTER OF ARTS \\ in \\ HISTORY
}

Portland State University 
TO THE OFFICE OF GRADUATE STUDIES AND RESEARCH :

The members of the Committee approve the theșis of Stephen A. Nicholls presented 26 January 1979.

Bernard V. Burke, Chairman

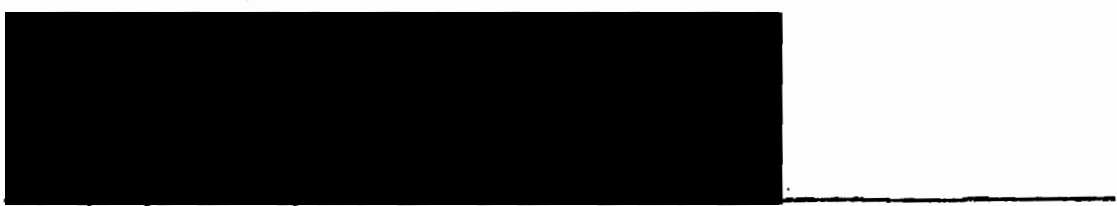

Jim F. Heath

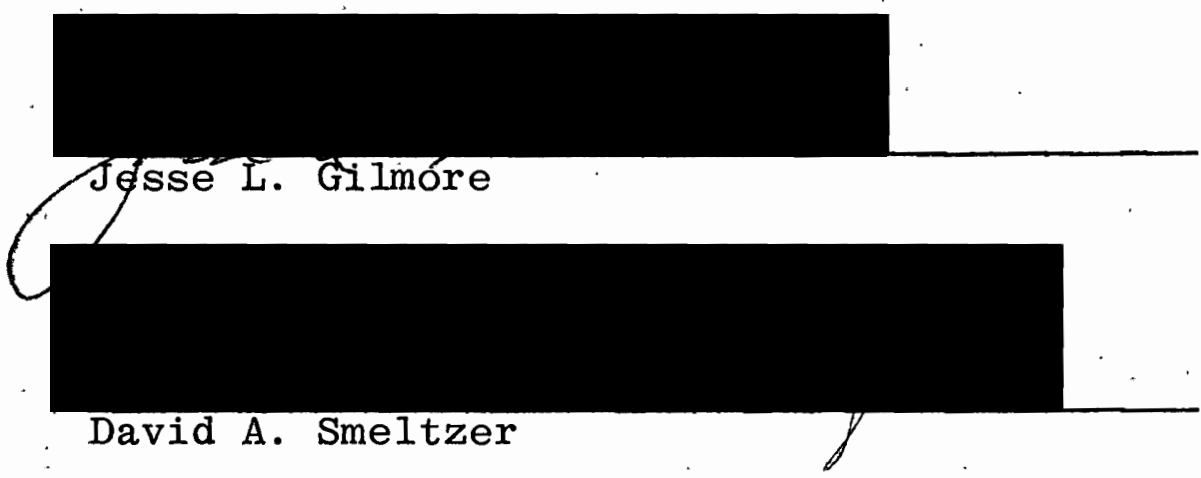

APPROVED :

Michael Rearaon, Head, History Department 


\section{ACKNOWLEDGMENTS}

There is no other point in his career when the budding scholar is more dependent upon other people than while he is working on his master's thesis. Not yet polished in the intricacies of scholarly research, he must heavily rely on the direction and advice of his mentors. My debts are huge.

If it were appropriate to dedicate a master's thesis, then this should be inscribed to Dr. Bernard V. Burke, professor of history at Portland State University. This work is really his. As both thesis adviser and chairman of my graduate committee, Dr. Burke assisted me through numerous classes and seminars, stimulated my interest in American diplomatic history, and provided major guidance in delineating my research subject. More than this, he provided me with a wealth of primary resource material which he painstakingly collected from libraries and archives throughout the United States; material which, without his efforts and generosity, would be beyond the reach of most graduate students. (Unless otherwise noted, photocopies of manuscript material cited in this thesis are in the possession of Dr. Burke at PSU.) Dr. Burke's insights and direction proved to be the single most important aspect in the writing of this thesis.

A sincere note of appreciation goes to Dr. Jim F. Heath. His careful reading, editing and critique of this 
work strengthened its content, style and organization. Dr. Heath's help during this past year and his constant friendship throughout the many years of my stay at Portland State, have been sustaining encouragements. The other members of my graduate committee, Dr. Jesse L. Gilmore and Dr. David A. Smeltzer, bravely read through this thesis and I thank them for their constructive criticisms, questions, time and patience.

Special thanks go to David Stubbs and David Yamasaki for reading through this document, the latter while confined to a hospital bed; and to Mary Dozark for typing the final copy and seeing it through to its last stages.

My employer, Catholic Relief Services -- USCC, graciously allowed an extended leave of absence from overseas assignment to enable my return to Portland to complete my graduate program. However, my deepest gratitude goes to Maureen McNassar who brought me back home and made me finish the project I started years ago.

Stephen A. Nicholls Sandy, Oregon January, 1979 


\section{TABLE OF CONTENTS}

PAGE

ACKNOWLEDGEMENTS . .................... ii

INTRODUCTION .......................... 1

CHAPTER

I THE HISTORICAL CONTROVERSY $\ldots \ldots \ldots \ldots \ldots \ldots$

On Behalf of the Professional........ 7

In Defense of the Amateur.......... 19

Searching for the Best Man.......... 30

Some Criteria for Judgement......... 39

I I THE HOOVER COMMITMENT.............. 46

The American Diplomatic Corps:

1920s Status Report............ 48

The Hoover Apprenticeship.......... 53

The President's Policy.............. 60

The Stimson Influence............ 64

The Context for American Diplomacy

Toward Europe in 1930.......... 68

II A CASE STUDY: AMBASSADOR FREDERIC MOSLEY

SACKETT'S ASSIGNMENT TO GERMANY....... 78

Mr. Sackett Goes to Washington........ 81

Summons From the White House:

Sackett's Appointment.......... 88

Ambassador Sackett and His Reception

In Germany................. 102

Sackett and Germany's Financial Crisis... 110 
CHAPTER

PAGE

Sackett's Popularity in Germany......... 145

The Ambassador and the Election of $1932 \ldots \ldots \ldots \ldots \ldots \ldots \ldots 149$

IV CONCLUSIONS -- RATING AMBASSADOR SACKETT..... 156 NOTES

SELECTED BIBLIOGRAPHY 


\section{INTRODUCTION}

With few exceptions, aspirants for the job of President of the United States have frequently made an issue out of promising to appoint professionals to all ambassadorial posts and halt the age-old practice of placing noncareer spoilsmen in diplomatic positions as "pay-offs" for campaign contributions, old favors or old friendships.

Once elected, however, the promises of the campaign become memories. The new president, subject to the realities of his office, often compromises the lofty ideals he enunciated before election day. Indeed he will appoint professional foreign servicemen to many of the higher level diplomatic positions in embassies, legations and within the State Department itself, perhaps more so than in previous administrations. Nevertheless, a share of the available positions -- often the more prestigious and comfortable ones - - go to people outside the foreign service who are untrained in the intricacies of diplomatic practice.

According to the United States Constitution, the power and responsibility for appointing American diplomats is clearly invested in the Executive Branch of government (Article II, Section 2) with the advice and consent of the Senate. Although some ambassadorial nominees are purely political appointments, the Senate generally grants its 
approval as a routine matter and it usually does so without undue delay. In cases where the nominee is a former member of the Senate, that body's long-standing custom is not to raise opposition to the appointment. As courtesy to a sitting Senator nominated to hold a diplomatic post, his nomination by-passes the appropriate reviewing committee altogether and is approved via Senatorial acclamation. Despite the constitutional responsibility of the senate, the politics of getting along with a new administration in the White House often leads to cursory review of the qualifications of diplomatic nominations.

When an appointment of a diplomatic nonprofessional is made by the President it commonly stimulates much in the way of general criticism: If the appointee is wealthy, he bought the post; if he is a party politico, he is grossly inexperienced to handle foreign affairs; if he is holding a political office at the time of his appointment, he is being gracefully gotten out of the way. However, after he has completed his assignment, little attention nor real assessment is made of the appointee's actual job performance or the ratings given to him by his colleagues and contemporaries who worked with him. Hence, any really fair assessment of his contribution to the conduct of American foreign affairs is denied.

The important role of the ambassador in the function of foreign relations should not be underrated. The Brookings 
Institute, in a 1960 report to the Senate Foreign Relations Committee summarized the ambassador's function:

He is the eyes, ears and voice of the United States in the country of his assignment. It is chiefly through him that governmental relations with that country are funneled. He is the primary agency of negotiation with the host government and the image and embodiment of the United States to its officials. For the U.S. Government, he is the central source of information on what its multifarious agencies are doing under his general supervision. He is the primary source of intelligence and advice to which his Government looks in formulating its policies. He sets the bounds for the activities of all other U.S. officials within his jurisdiction and in times of emergency exercises a large measure of authority over other Americans as well. Probably more than any other official below the level of Secretary of State, an Ambassador can make a shambles of U.S. relations with another country or organization, or can save it from irretrievable blunders.*

The contention of this paper is that perhaps the noncareer, nonprofessional appointment to diplomatic positions is neither necessarily a bad thing nor should it be considered undesirable given the American system of conducting its foreign affairs. More often than not, the circumstances of the moment and the state of world political and economic conditions intervene to dictate the need for talents from outside the regular diplomacy machine of the State Department. Despite the criticism at the moment of appointment, the only real assessment of a diplomat's performance can be

*Brookings Institute, United States Foreign Policy -Formulation and Administration (Washington, 1960), 110 . 
made by looking at his record during his assignment.

In order to fully explore this thesis a "case study" is taken from the Administration of Herbert Hoover. While Franklin Roosevelt was noted for his distrust of the professional diplomats and made no absolute promises to promote them, his predecessor in office was clear in his commitment to the career diplomacy for the United States. As the first president in modern times who vocally emphasized his preference and support of the concept of a professional diplomatic corps, especially after the passage of the 1924 Rogers Act which essentially established America's first career foreign service, Hoover personified the ideal of professionalism above political expediency. In fact, Hoover appointed more career men to ministerial posts around the world than had any president before him. When it came down to political necessity, however, even Hoover found room for the political spoilsmen.

Chapter I of this paper deals with the historical controversy over the merits of appointing professional diplomats from the career foreign service versus the practice of selecting amateurs from the political spoils system. Arguments from both sides of the debate, as well as several middle-of-the-road positions, are presented and from these a number of criteria are extracted to be used in the assessment of'an amateur diplomat's performance.

Chapter II concerns the Administration of Herbert 
Hoover in the period 1929-33 and delves into his commitment to the professional foreign service at the time; the influence of his Secretary of State, Henry L. Stimson, on the conduct of foreign affairs; and the environment and international problems, particularly with regard to Europe, as they were faced by American foreign policy makers.

Chapter III, building upon the previous section is a case study of one of Hoover's noncareer ambassadors whose appointment drew criticism not only from contemporaries at the time but later from historians as we11. The subject is Frederic Mosley Sackett, United States Ambassador to Germany during the critical period of 1930-33 when the Weimar Republic went into eclipse and Hitler succeeded in gaining the high position of Chancellor for the Reich. Chapter IV, after reviewing Ambassador Sackett's political and diplomatic careers, is an analysis of his performance made against the criteria listed in Chapter I, with conclusions based upon analysis. 
CHAPTER I

THE HISTORICAL CONTROVERSY

Historians, political scientists, diplomats and politicians have constantly disputed the subject of career versus noncareer appointments of American ambassadors, often in the framework of the contest between the professional and nonprofessional for control of America's foreign policy. America's unique status of democracy has lent itself to a corresponding unique blend of both amateurs and professionals representing the United States abroad, especially in the Twentieth Century, not commonly found in other diplomatic corps of the world. This combination has produced a diplomatic representation which seeks to reflect the ideals, styles, culture and philosophies which are considered truly "American" while at the same time aspires to a level of professionalism thought exemplary of a great world power. The emerging debate is relatively basic: In which hands are the United States and its foreign policies best served?

Some authorities insist that the argument is as old as the Republic itself. Others foel it is a relatively new theme coming into serious play only since the 1920s when Congress legislated an upgrading in the status, training and 
salary grades of the professional foreign service inside the State Department. In light of these divergent views, the matter of the relative fitness of American diplomatic representatives of both genres, but particularly from the amateur ranks, is constantly questioned.

A number of questions arise which can be helpful in assessing the merits of appointing to ambassadorial positions persons who come from outside the professional diplomatic corps. First, however, it is useful to compare some of the positions reflected by proponents of the professional corps with the arguments raised by those who feel that amateurs have a definite role to play in America's diplomacy.

\section{On Behalf of the Professional}

Writing in 1909, a former Assistant Solicitor and Consulate official for the State Department said that while representatives at the more important diplomatic posts have always been carefully selected by the President in order to reflect sympathy with his foreign policies, lesser status posts have been vulnerable to political patronage and have "sometimes been bestowed without special regard for the fitness of the individual for the place." In his primer entitled Our Foreign Service; The A.B.C. of American Diplomacy, Fredrick Van Dyne, through the use of anecdotes, implicitly takes to task the fact-of-life use of political patronage appointments in diplomacy. He cites Secretary of 
State John Hay's reference to the custom of appointing to foreign missions members of Congress who had been defeated in re-election bids: "A quiet legation is the stuffed mattress which the political acrobat wants always to see ready under him in case of a slip." Added to this was Secretary William Seward's comment that "some persons are sent abroad because they are needed abroad, and some are sent because they are not wanted at home."1

In the early part of the Twentieth Century, writers had to rely upon anecdotes to make their point regarding amateurs mainly because American diplomacy was largely dominated by the nonprofessional appointed by partisan officeholders. By mid-century, however, after the 1924 Rogers Act insured a strong nucleus of careerists, the cause for a more professional foreign service had found enough friends to enable proponents to become increasingly more forceful in their arguments against the appointment of political spoilsmen to serve the cause of American diplomacy. Not unexpectedly, the most vehement voices against the amateur appointments were those from persons who came up from within the professional ranks.

Charles W. Thayer's Diplomat is essentially a call for primary reliance upon the professional in the conduct of American foreign affairs, especially at the ambassadorial level. As late as the end of the 1950s the spoils system continued to dispose of so many diplomatic posts such that, 
at the time of his writing in 1959, on $1 \mathrm{y}$ four of 14 American ambassadors in the important Western European posts were held by professionals. Only because of appointments to the non-European posts, especially those in out-of-way places that do not ordinarily attract office seekers, was the percentage of professionals on a global basis somewhat higher. "Even so," Thayer stated, "about half our embassies are still headed by amateurs whose only training has been as successful bankers, salesmen or race-horse breeders." Not all were failures, he admits, and indeed "some have revealed the rare talents of a born diplomat."2 But on the whole, the United States continues the "export of fools in the guise of diplomats." 3 .

Because the system permits it, the essential requisites of good foreign representation are all too often overlooked when they get in the way of domestic political expediency. Hence, American representatives abroad are often wealthy men with social ambitions who were able to enhance their chances for a diplomatic post by means of a significant contribution to a winning political party. Newspaper editors who support a presidential candidate "can often count on an embassy for themselves or some member of their families," and lawyers helping a candidate out of a messy situation get ambassadorial appointments. Further, Thayer asserts, "Exile to an embassy overseas has long been a way to sidetracking political appointments." The national 
committees of both major American political parties continuously keep an eye out for possible openings for loyal party workers regardless of their qualifications to hold a diplomatic post. ${ }^{4}$

In Thayer's view the most important qualification for a diplomat is good political sense, the ability to sense the significance of political force on a given problem and to guage the resultant reaction. The ambassador must be able to distill from available political data what meaning it may contain and to "detect from a combination of observations trends of opinion, of subtle shifts in policies." Yet, too often, the inexperienced diplomat assumes the role of advocate for his host country $v i s-a-v i s$ his own. Anxious to be loved, he becomes blinded by his hosts. "The result is that his dispatches take on the color of a lawyer's brief rather than a dispassionate objective report." And on the occasions when "his love is rebuffed," the spurned ambassador may take every occasion to condemn his host unfairly. ${ }^{5}$

Being a lawyer does not necessarily provide the political savvy needed to be a good diplomat for "law in some respects is even less suited as training for a diplomatic career than the military profession." Thayer adds, "In fact [Sir Harold] Nicolson maintains that the 'worst kind of diplomats are missionairies, fanatics and lawyers.'" There are strong superficial arguments involved in the similarities between law and diplomacy; they both deal with 
debate and compromise, require an ability to negotiate and a good knowledge of human nature. "But when the lawyer turns to international problems, these similarities lead him to the false conclusion that diplomacy is a form of law." In diplomacy, as opposed to law, right is not alyays distinguished from wrong, legal from illegal, and traditions, customs, histories and moral concepts vary greatly in different countries. The lawyer, Thayer states, is prone: to getting bogged down in the fine print of diplomacy without ever really getting to its substance. ${ }^{6}$

Thayer is especially critical of the idea that businessmen are well suited to diplomatic careers.

It is widely believed, particularly in America, that diplomatic negotiations are essentially business deals and that the best negotiator is therefore a shrewd Yankee horse trader operating under the cover of a pair of striped pants. As a result a number of successful businessmen without diplomatic experience have found themselves pantless and shirtless at the end of a negotiation with experienced diplomats.

Here the fundamental differences include style and politics. Whereas business is conducted within a framework of regulated systems under the "law of contracts" with a heavy emphasis on "advertising one's saleable points," unlike the businessman, the diplomat cannot pick and choose his associates but must deal with the political power that rules. Nor is the diplomat's negotiation ever final, since differences over even the most precisely worked out agreement or plan will arise. ? 
Thayer's book, therefore, is largely a statement on behalf of the well-trained professional diplomat serving the public interest above and beyond the bonds of political debts, petty blackmailers and prestige seekers. He decries the point that, all too often, those professional diplomats who make it to the rank of ambassador "often find their careers suddenly terminated when their resignations are accepted by a party in power in need of patronage posts." Despite the establishment of the career foreign service in 1924, even professionals are expected to resign their commissions when a new administration takes over the white House. "After every election," Thayer wrote, "the party patronage staff within the State Department sits down with the professional personnel director to divide the spoils. It has become a political tradition for presidential candidates to pledge their support of the career principle and to promise not to replace career ambassadors. However, in view of the automatic resignation procedure, "it is relatively easy to circumvent such pre-election pledges." 8

The fact that, statistically speaking, the number of professional diplomats has increased over the years does not impress Thayer.

This statistical game is fairly simple to play no matter what inroads the patronage committee has made on the embassies, since the number of embassies has in recent years steadily increased with the creation of new independent states, many of which political office seekers do not consider desirable. ${ }^{9}$ 
Thayer acknowledges there are some arguments in favor of noncareer appointments.

Every political generation produces a half dozen or more individuals capable of making a distinguished contribution to diplomacy without going through the long and arduous training of the professional service.

But nothing will replace experience or the knowledge of a country and its disposition which presumably the professional has. 10

A more devastating assessment of the amateur as compared to the professional in diplomacy comes from Ellis Briggs, a former career diplomat, who contends that no single factor is more discouraging to the career man than the practice of awarding ambassadorial posts to nonprofessionals, especially when the beneficiary "is an outright purchaser or one whose claim to consideration rests on dubious or publicly weakened foundations." His book, Farewell to Foggy Bottom -- The Recollections of a Career Diplomat, is the retired diplomat's parting shot at the problems he has'seen in the conduct of U.S. foreign policy. ${ }^{11}$ Briggs terms those defending nonprofessional appointments as "apologists" and he does not see much defense in appointing even outstanding men and women who are successful in other areas and who might have talents and abilities for a special posting to diplomatic positions. He argues:

The point is that practically no outsider, however talented, can be so effective at representing the United States abroad as can the outstanding professional trained for the job -- the officer who 
has risen to the peak of a competititve professional career and who has already proved in important missions successfully completed, his fitness for the topmost positions in the diplomatic service. 12

A particular sore point in Briggs' view is that in a coveted post a nonprofessional usually "bumps" the career chief of mission and "only in rare instances has another post been found for the displaced professional." This method, Briggs asserts, severely damages the career man's credibility and effectiveness. ${ }^{13}$

A further argument Briggs presents against the use of the nonprofessional is that, despite his reputation, he is apt to be unwelcome to the foreign government "already disillusioned by past experience with amateurs." The host government would put up with the appointment hoping that he would be restrained by a knowledgeable deputy, or in hopes that the nonprofessional "will soon return to his campus, fleshpot or factory."14 The host government puts up with such amateur appointments only in hopes of putting the man in their pocket or out of fear of offending whichever administration might be in the White House at the time. And often the amateur ambassador's role is held to a minimum, in which case the business of the foreign government with the United States is adequately protected at the expense of the business of the United States with the foreign government involved. "The only losers," Brigss states, "are the American government and people." Further he asserts it is a 
"shameful thing that the American government, for the greater satisfaction of a handful of politicos of the dominant party, goes on handicapping itself in its dealings with other nations."1 5

Few amateurs can compete with professional foreign service officers because, as a newcomer, he lacks experience in the practical functioning of diplomacy, he works in a strange atmosphere, and must use tools that are new to him, according to Ambassador Briggs. Diplomacy is an imprecise business and there is a "feel for and a familiarity with it" which are acquired "by skill of operation of the machine of foreign affairs and in no other fashion." The only thing that is predictable about diplomacy is its unpredictability and

...that is one of the things that a foreign service officer learns day by day and year by year as he progresses through the grades of a competitive service. That is one of the things that cannot be learned overnight, not even by the most gifted amateur envoy. ${ }^{1}$

Personal popularity of a diplomat, Briggs states, is not essential for a successful performance and the amateur is rarely aware of this. Respect is more important than good public relations but "a political ambassador is often convinced that cultivating his public relations garden is the most important activity in which he could possibly engage abroad."

An ambassador is an appointed official. Moreover, he is not accredited to the people of a foreign 
country but to their government, which is not operating a popularity contest or seeking to determine whether Mr. Universe will turn out to be the Chargé d'Affaires of Upper Volta or the ambassador of the United States. What the foreign government is trying to find out is what the United States will do if the tariff on frozen poultry is raised, and what it wants. from the American representative within its gates is dependability and accuracy of judgment in reflecting the Washington point of view -- just as the American government values the same attributes in the foreign diplomatic representatives assembled in Washington. ${ }^{17}$

If Briggs is hard on the amateur diplomat his view is, nevertheless, quite representative of a general feeling held within the ranks of the United States Foreign Service, especially since the 1920s when the career service was upgraded in status and qualification demands. After more than 30 years in the state Department Briggs himself is a product of that early foreign service and it is likely that his bias is based in large part upon career abuses endured or opportunities lost due to interference by a political appointment.

A prominent careerist, Hugh Gibson, raised the question that the political appointee is perhaps more beguiled by the flattery and social attentions given an ambassador than would the professional who most likely would recognize the attention for what it was -- a courtesy and consideration calculated to lubricate the "wheels of diplomacy." The political appointee accepts such courtesies as being extended to him personally and often succumbs to such charms by extolling the virtues of the country to which he is 
assigned. "This often leads to his becoming an active propagandist for the country to which he is accredited," that is, sort of "placed in one's pocket" as it were, and vociferously promoting his host country's interests rather than the interests of the United States. ${ }^{18}$.

A less extreme point of view is reflected by another former ambassador and career foreign service officer of the same generation as Briggs. In an article for Foreign Affairs concerning the future of professional diplomacy in America, George Kennan does not criticize the politically appointed representative but offers vigorous support for increased reliance on the career officer,

not to serve as a museum exhibit of the external
habits and demeanor of the average American [as
has often been an argument posed in favor of the
noncareer diplomat], but to constitute an effec-
tive channel of communications with the other.
government and a perceptive observer of life
in other countries.

His article, and indeed much of his personal activity after leaving the foreign service in 1950, advocated improvements in the training, quality, salary and status of the U.S. diplomatic corps. ${ }^{19}$

Outside the realm of the professionals themselves, there have been ardent defenders of the career man as opposed to the political appointee, some of which have emerged from politicians. Prompted by several politicallybased appointments to the foreign service made during the Eisenhower Administration, the United States Senate, during 
the summer of 1957, engaged in a debate over the issue.

This is significant since, under the American Constitution, the Senate shares responsibility with the President for the quality of American diplomatic representation abroad.

Major criticisms came from Democratic Senator Hubert Humphrey who blasted the Eisenhower Administration for having "forgotten his campaign pledge of 1952" by appointing political campaign contributors as ambassadors instead of the "best men and women, the ablest and most reliable in the land," as he had promised. Although the Secretary of State (John Foster Dulles) had pointed out that under Eisenhower, the highest percentage ever of career professionals were at that time serving as chiefs of mission (more than 70 percent in 1952, Humphrey noted), still, a significant number of American ambassadors were large financial contributors to the Republican part in $1956 .^{20}$

Humphrey's charge was reinforced by New York Times columnist James Reston who also castigated Eisenhower for not living up to his avowed principle.
The issue is not whether the Eisenhower Adminis- tration is being more political in its ambassa- dorial appointments than the Democrats, or whether these jobs should be given to the top career men in the foreign service, but whether the appointments have met the President's principle of appointing the best men available, regardless of party, wealth or foreign service record.

What had occurred by 1957, in Reston's view, was that the administration had reverted to the "porkbarrel system" 
of appointments. ${ }^{21}$

In his Senate speech, Humphrey asked that the United States "stop treating our ambassadorial appointments as though they were casual or relatively unimportant," and he pleaded for greater dependence on the foreign service. He felt it necessary to judge appointments on the basis of individual merit, background, experience, education and knowledge of languages. Humphrey also stressed that the Senate itself should be more careful in its screening of referrals from the president in the future. 22

\section{In Defense of the Amateur}

If the period during the Eisenhower Presidency produced an abundance of criticism of politically appointed amateurs to ambassadorial positions, the charges did not go long without a response from those generally finding good aspects to be considered on behalf of the amateur diplomatic appointee.

An interesting rebuttal came from one of the wealthy amateur appointments made by President Eisenhower -- Mrs. Claire Booth Luce. In her essay "The Ambassadorial Issue: Professionals or Amateurs?", published in Foreign Affairs, she attempted to weigh the relative merits of both sides of the dispute and emphasized that the issue was in her view a relatively new one essentially arising since the passage of the Rogers Act of 1924, which provided for better training of career diplomats. It had not, she argued, emerged as a 
major issue until after the Foreign Service Act of 1946 , wherein the rank of "career minister" was created which enabled professionals to move higher up in the ranks without jeopardizing their position within the foreign service. ${ }^{23}$

In defense of the Eisenhower Administration Luce pointed out that, as of 1955, all important "sensitive or crucial" posts had career men in charge with 22 out of 76 posts held by noncareer appointments. Although the major European capitals were included in her list as less sensitive posts, she stated that the nonprofessionals at these had some previous experience in foreign affairs. ${ }^{24}$ But the crux of her statement was, like it or not, money remained a factor in getting and maintaining embassies especially in the European capitals. While private wealth should not be a determinate factor in making an appointment, "the President today faces the necessity of picking only very rich men for. certain posts." Rome, London and Paris, for example, "are posts around which a dollar curtain has long been drawn. They can be assumed for any reasonable length of time only by men with private fortunes.":25

Luce further argued it was often desirable to have a "Somebody with a capital S" -- a proven man of distinction representing the United States abroad rather than merely a competent but relatively unknown career man. For when a man has made it in his own country, has acquired great prestige through his own efforts, has demonstrated interest in public 
affairs, has wide contacts with other leaders, and enjoys the prestige that comes from personal friendship with a President or Secretary of State, such factors give him much influence in the country of his appointment. And as for the "political pay-off" appointment, she stated, this was nothing new since virtually all appointments made by the "Top Politician" including career envoys, were by definition political appointments: ${ }^{26}$

Certainly there is a large measure of public agreement on what constitutes a "political payoff." In American political practice, the personal convictions of an appointee; the size of his private fortune; the campaign contributions he has made in the past to the party of his choice; the private services he has rendered the party; his personal relation to key figures in government (such as his blood relationship, friendship or business association with them) -all are considered to be circumstances which such as neither qualify nor unqualify him as a candidate for any high office. But when these same circumstances are presented as being qualities or virtues of the candidate's person; especially when they seem to be his only qualifications for the job to which he aspires, it can be assumed -- and the assumptions is generally a valid one -- that the appointee is a "political payoff."27

As a rebuke to the Senate, Luce argued that the upper house of Congress existed as a check on Presidential appointments and can disqualify them when there are grounds to do so, even in cases where the designate is a "crony" of someone high in government. So if a mistake occurs, the fault lies as much with the Senate Foreign Relations Committee as with any one involved in the process; "...too many of the Senate's members -- opposition no less administration -- 
still regard ambassadorships as a part of the political spoils system."28

In point of fact, the Senate has rarely failed to confirm a President's nomination to the diplomatic service regardless that many might have been based on political motivations." "While the Senate has occasionally balked at particular nominees coming from outside the foreign service, its proper inclination," according to Richard C. Snyder and Edgar S. Furniss Jr., "has been to respect the desire of the President to have a crony, confidante or a career man representing him personally abroad." In their 1954 study of American Foreign Policy, Snyder and Furniss argue that despite past abuses, there was much to be said in defense of the President's right to go outside the foreign service in naming his personal representative to foreign posts. ${ }^{30}$ The success of a mission generally depends upon the extent to which the representative correctly interprets the foreign policy position of his own country to his assigned head of state as well as how he correctly reports back to the United States the policies, goals and practices of his host government. "The nature of this dual role demands from the diplomat the quality of objectivity," according to snyder and Furniss. ${ }^{31}$ But in the American system of democracy the ambassador is more than the representative of the people of the United States; he is the personal representative of the President who appoints him. ${ }^{32}$ 
Before the Foreign Service Act of 1946 there was a statutory requirement that a foreign service officer, when appointed ambassador, had to resign from the service. "This provision served to emphasize the intimate, political relationship between an ambassador and the President," the authors state. Granting the existence of past abuses in that the political appointive power was used to reward "worthy supporters" of the President -- and that, in the past, the caliber of such men was apt to be low -- Snyder and Furniss argue the continual raising of qualifications has tended "to increase the ability of political appointees, to lower the ratio between political appointees and men in the career service, and to increase appointments of able men." This way, the President can still bring to his diplomacy "men of highest qualifications whose experience and stature have been gained elsewhere"; businessmen for example. ${ }^{3} 3$

It is frequently. important, the authors state, that both the President and the foreign government involved know the ambassador is in fact as well as in theory the personal representative of the President, "that he speaks for the President, knows the mind and thoughts of the President, has access to him if need be; that he is, in other words, something beyond a civil servant, a single member of a complex bureacracy." 34 Perhaps more than courtesy is involved when the United States Senate speedily approves a 
President's nomination. In doing so, perhaps the Senate is generally recognizing and respecting the time honored privilege of the President to place his own men as he deems best. ${ }^{35}$

In a study for the United States Senate's Committee on Foreign Relations concerning the formulation and administration of American foreign policy, the Brookings Institute suggested that while ambassadorial appointments from outside the career service would face many on-the-job difficulties, such appointments can make, and have made, significant contributions. The major question confronted by the Institute was not whether there ought to be noncareer appointments to high embassy posts or not; but rather what the balance between career and noncareer appointments should be ${ }^{36}$

In 1960 when their report was published, 24 out of 75 chiefs of mission were noncareer appointees and these frequentiy had a better knowledge of American society than did the career types, thus making them more representative of America to foreign communities to which they were assigned. Invariably the political appointees had "strong roots of support and influence at home that can be of service in strengthening relations with other governments." In addition, they often demonstrated exceptional ability in one or more fields of endeavor and in some cases brought valuable executive skills to the job. "They inject a fresh, nonprofessional view," the report stated, and they reflected "one 
of the strengths of the American system of relatively high mobility between Government and private life."37

One of the major reasons why only six of the major Western European posts were held by career officers in 1960, according to the Brookings report, was due to the fact that private means were still "considered necessary to supplement the available governmental allowances" in some of the more important posts. ${ }^{38}$

If blunders occur, it is apt to be due to insufficient training in the fundamentals of diplomacy received by the noncareer appointments, as they are seldom in the service long enough to get it. This places a heavier burden on subordinates, but the Brookings report did not suggest that only the professional should be relied upon.

The important consideration is that the post of chief of mission is of such vital importance in building effective relations with other nations that it should be filled with only the most highly qualified individuals -- whether career or noncareer. ${ }^{39}$

Closely following the 1960 Brookings report was Kenneth W. Thompson's American Diplomacy and Emergent Patterns which contains a rather vehement defense of the noncareer appointment, sometimes at the expense of the career foreign service officer. His thesis, like that of Snyder and Furniss, is based largely on the President's dominant role in foreign policy making. Since it is the President who makes the central decisions in foreign policy, he must have the right to select top diplomatic officials 
just as he has the right to choose the members of his cabinet. Thompson argues that being forced to retain an ambassador associated with a predecessor's foreign policy or holding conflicting beliefs with a President's philosophy could have an unfortunate effect on the President's foreign policy. And further, to avoid atrophy and a conservative "stand-pat" approach to foreign policy, the introduction of fresh ideas and new leadership via the introduction of a nonprofessional can help an administration rise above this problem. 40

"An additional argument for the amateur derives from the possibility of attracting men of outstanding talent" to serve -- although they are not in the regular foreign service -- and perhaps such talent would have had the previous opportunity to be tested in the political arena. Thompson relies heavily on history to support his argument. In the Colonial and Nineteenth Century periods of American History there simply was no qualified corps of professional diplomats through which presidents could conduct foreign affairs. Nor for that matter did Congress appropriate any significant sums to provide for such a service. Diplomats in the earlier days had to be drawn from the "old masters" of American politics. Later presidents were able to draw upon the talents of a broad group of educators, journalists, university presidents, businessmen, plus a "fair share of scholar-diplomats." 41 
As late as 1914, "not a single one of our missions in the great capitals could boast a professional as its head." But in little over four decades, Thompson states, the change toward more professionals was "a little short of breathtaking." By 1939, out of 51 chiefs of mission, 25 were drawn from the career ranks and, by 1956 the ratio would increase to 48 out of 75 . As of March, 1960, the ratio was 74 out of 97 . Of the mission chiefs in the Kennedy Administration, 70 percent were career officers and, of the 28 political appointees, half were drawn from education, law or journalism while nine came from other government positions. ${ }^{42}$ In other words, the professionals had little room for complaint.

Such a stride was due in large measure to the passage of the aforementioned 1946 Foreign Service Act which provided raises in the salaries for ambassadors and staff and which facilitated the rise of professional foreign service officers to at least the rank of minister without losing his career status. Despite this rise in the star of the career man, Thompson argues that the performance of the nonprofessional has not been bad nor has it proven detrimental to American foreign relations. 43 "More than 2,000 ambassadors, ministers and charge d'affaires have served their country in a little more than a century and a half," Thompson wrote. "Few observers could have foreseen the achievement or failures of individual ambassadors in advance. While all 
would agree that the times are too serious to send innocents abroad, the requisite qualities of the successful envoy are difficult to assay. in advance."14

Clearly when it comes to making a diplomatic appointment, the goal should be professionalism "within a broad and inclusive definition that recognizes excellence and capacity manifested within and outside the Foreign Service."45 Thompson bases this contention on the assertion that, despite their professional training, foreign service officers "have all too frequently lacked the administrative experience essential to their task." Thompson sees a problem in stressing the specialized responsiblity of the foreign service officers in economics, politics, etc., at the expense of diplomatic know-how. "The diplomat today, no less than yesterday, must be a man of extraordinary human resources." 46

Debunking the myth that "political appointees are all amateurs," especially where ambassadors are concerned, is one of the goals of James L. McCamy's The Conduct of the New Diplomacy. He argues that, despite the increasing trend since 1924 to appoint career men to ambassadorial positions, they are the ones who carefully preserve the myth of the inept amateur. ${ }^{47}$

McCamy's major statement in this regard is that "Not a11 noncareer ambassadors are amateurs," in that, especially since the years after World War II, only one in five noncareer appointments had no previous government experience 
in foreign affairs. ${ }^{48}$ Many had gained some experience in foreign affairs while serving in the military; others, such as W. Averill Harriman whose diplomatic career spanned four Democratic presidential administrations, were called upon to assist the war effort from essentially private careers. "Mr. Harriman is hardly an amateur. Yet he is certainly a political appointee," McCamy asserts, "a partisan who serves his party as well as his country."49

Those without government experience are not necessarily incompetent, McCamy states, as "some extremely successful ambassadors got their first government experience in foreign affairs in their first posts, although they may have had international experience in journalism, business or civic affairs." Citing such examples as Claire Booth Luce, Arthur Dean and Eugenie Anderson, McCamy suggests that "good ambassadors" do come out of Congress, political parties and law firms, among others. ${ }^{50}$

Yet, writing in 1964, McCamy is perhaps overly selfassured when he suggests that no President "in these times" would appoint an incompetent person to high foreign affairs posts. Ambassadorships cannot now be bought as contributors must "appear to be competent and prove to be so if they stay in the work. Foreign affairs are too important to the reputation of any President to play loose with the choice of either political executives or ambassadors." 51 He bases this argument on the hope that, in a democracy, attitudes 
of political leaders are more crucial than their skill. The man who wants the political post, including ambassadorial ones, is pre-selected as someone who can be trusted to be such a political executive in a democracy. He is eligible to be a leader, and according to McCamy "Only his kind should be eligible." 52

In a free society, McCamy asserts, "only those who are interested in public work should be considered eligible for that work." If, in the American system of picking political leaders from the President on down, the object is to get the most competent from among these eligibles it is then the best of systems. In the case of leaders for foreign affairs; McCamy says the system has worked better than not, for "the quality of political chiefs is high." 52

Searching for the Best Man

Arguments recognizing the merits of both sides in the problem of career versus noncareer appointments have emerged from the general debate and these are perhaps most sensible insofar as attempts to apply a measure of objectivity in analysis. Essentially these views agree that despite some obvious bad points, the role of the noncareer appointment is a desirable one and they should, under certain circumstances, always be considered when ambassadorial appointments are made:

The first of these comes from Elmer Plischke's The Conduct of American Diplomacy. Plischke feels that both 
types -- the successful man from private life and the professional diplomat -- have advantages and disadvantages. The latter tends to be "more philosophically" inclined and has a greater professional detachment less subject to having his emotions played upon. The career diplomat often is prone to conduct himself and his activities primarily with a view to continuance in his assignment, a promotion, or at least with such discretion as to prevent the marring of his career. Plischke argues that

the career diplomat inclines to hedge in the making of decisions and to pass the buck [generally to the Department of state] while the man from the outside [viewing his status as a short term thing] is more likely to arrive at his own evaluations and decisions. Occasionally the career diplomat becomes so adept at fence-straddling that his position appears pitifully ridiculous to the outsider. The political appointees, on the other hand, are sometimes willing to accept only the more desirable, or less difficult assignments. ${ }^{54}$

The criteria for selection should not necessarily be whether the appointment comes from within the foreign service ranks, rather that the emphasis should be placed on the individuals' capacities and abilities, according to Plischke. The chief of mission ought not only relate well to people but be willing to understand them and their country, know the social, political and economic conditions of the state, be able to exercise leadership and command the respect of his staff and hosts.

Sometimes political appointments result in diplomats who have little interest in their assignments other than the enjoyment of a comfortable life 
overseas. But that is not to say that all appointments made outside the career service are undesirable nor does it imply that all designations from the foreign service are to be preferred in positions where a sympathetic understanding of the local situation is most desireous

Plischke stated. ${ }^{55}$ Where diplomatic problems are largely in the nature of business and trade, however, "it may be more logical to obtain someone with a business background directly from private life." 56

As do many critics of the American conduct of foreign affairs, Plischke reserved his strongest criticism of the diplomatic appointing systems for the tendency to place men from an "undemocratic stronghold of exclusiveness and wealth in the government service" particularly in the principle world capitals. "We are still likely to find that some of the prize diplomatic plums are left to the multimillionaires." But he acknowledges that not all appointments go to the wealthy and that "some men of wealth [the author cites Dwight D. Morrow as an example] have proved to be of exceptional value to the service." 57

A second viewpoint acknowledging both the good and the bad attributes of the professional and amateur alike, and studded with case histories to back up his arguments, is presented by E. Wilder Spaulding in Ambassadors Ordinary and Extraordinary. Spaulding deals mainly with the American spoils system and its effect on diplomacy. In doing so, he speaks with an 18 year background as historian, editor and officer for the State Department, an eight. year service with 
the United States Information Service and as a professor of history at Harvard.

For spaulding, the question of getting the best diplomats from the spoils system or from the career system is one that will always be debated as long as America's pofitical system continues. While Presidents in their election campaigns continuously argue for ambassadorial placement via a merit basis, they nevertheless continue to appoint diplomats from the spoils system. Spaulding himself leans toward favoring emphasis on using the professional diplomatic corps as the amateurs "have too often made bad bureaucrats as well as poor representatives of their country." However, he finds the "new blood" argument is often a convincing one in that several outstanding persons "have contributed far more than protocol and routine to the service."58 The role of the noncareer appointment should be considered, he states, but only "if the power of appointment is properly used." 59

It is understatement to say Spaulding is critical of the spoils system's usage for making diplomatic assignments: "In the opinion of thoughtful men and women," he writes, "it is doubtless the patronage system of appointment of chiefs of mission at the important posts which has damned the system [of American diplomacy] and lowered the prestige of United States Ambassadors more than any other factor." Created largely in Andrew Jackson's presidency, the spoils system 
has provided a rich fund of enticing rewards for political hacks and lame ducks as well as genuinely worthy statesmen -- awards that can be dispensed by the president with honorable mention going to the United States Senators, who must approve the nomination, and to the party in power. ${ }^{60}$

However, it was relatively recently that a career foreign service of any size could begin to fill the needs at the higher levels of diplomacy. Even during the first half of the twentieth century, the author acknowledges, the service was still "comparatively young and pathetically small." Due to these circumstances, amateurs were necessarily relied upon to fill the expanding needs of state for the United States. Plus, there were other arguments in favor of the nonprofessional: Fresh blood was continuously injected into the service; men of prominence and ability from outside the normal service's narrow training were enlisted; their appointment helped insure placement of politically sympathetic men in key positions; and, perhaps, they improved relations between Congress and the administration more so than. would a "colorless" unknown from among "the State Department Boys." 61

In addition to these factors, spaulding states the appointee from the spoils system might carry more prestige abroad, represent more diverse geographic areas than those within the career ranks and, if he is independently wealthy, his money makes the prestige posts "more affordable." Finally, "the spoils system often provides a dignified retreat for worthy or unworthy officials whose usefulness is 
at an end." 62

Spaulding returns to the basic objections to the amateur diplomats, that being their inexperience and their "inability to serve satisfactorily as a member of the team." He also states that, too often, the amateurs:"do not know how to deal with foreigners ... they are either stubbornly opinionated in their Americanism or so impressed ... so flattered by the new intimacy with great names abroad, that they lack balance." This tends to lead the state Department to discount their judgment and often forcing the amateur to fall back on his relationship with the white House. ${ }^{6} 3$

What follows is Spaulding's analysis, ranked by profession, of the performances of American amateur diplomats. These are worth noting in that, even given their lack of professional training and expertise, each group has the potential of adding strength to ambassadorial assignments.

Newspapermen have at least one trait in common with diplomats in that they must both be effective reporters. Both should possess keeness of observation, ruthlessness in separating the wheat from the chaff and facility in expression, according to Spaulding. But problems arise as their respective audiences are fundamentally different. The journalist writes for the world while the diplomat "often needs the assurance that the world will not read what he is reporting." There have been some noted journalists who 
have been successful as diplomats -- Josephus Daniels, Robert Worth Bingham, and Walter Hines Page for examples -- and others who were not so good. But on the whole, Spaulding generalizes, though journalistic integrity is not àlways incorruptible, "his integrity as a sound reporter should make him more useful to the Secretary of state than his colleagues from many other professions."164

"Men of Letters" in the early days of American diplomacy emerged from the spoils system at a time when the nation was smaller and

a distinguished author could not help knowing many of the distinguished statesmen of his party or section; they wrote their campaign biographies or supported their causes in book and periodical and it was only natural that there should be a pay-off in the form of an assignment to a foreign post.

At the same time, spaulding asserts, those were the times when there was no career diplomacy to "decry" the appointment of a Washington Irving, a Bayard Taylor or a James Russe11 Lowe11. The "Men of Letters" perhaps serve best in cultural posts especially when there are no:troublesome issues involved between Washington and the host country. ${ }^{6}$ College presidents and ambassadors have much in common, Spaulding states, as both must be adept at negotiations, have a certain aura of distinction and intelligence, administrative abilities and "a genius for getting to know people, working with them, and persuading them." Spaulding is surprised that so few college presidents are appointed to diplomatic posts but "the eminent ones have usually been very 
busy men with no desire to expatriate themselves over long periods of years." The record of those university presidents who stayed for any significant period seems to show that they "made tolerably good ambassadors." 66

Historians, however, have proven to be a generally mixed 1ot. In Spaulding's opinion they "don't always make good diplomats," (and, incidently, "diplomats rarely make top-notch historians"). Some, like Charles Francis Adams and John Hay, rank among the greatest. Others, Spaulding states, such as William E. Dodd, make great historians but are "unsuccessful" ambassadors. ${ }^{67}$

Women as ambassadors are hard to assess as there have been so few of them to hold high diplomatic posts. Of the six Spaulding considers they have made, as a group, "a very fair record of accomplishment," and certainly enjoyed good press as well. Yet, with the exception of one woman who rose through the career ranks, all played politics. "Each was a political appointee of the most blatant sort" and none had previous diplomatic experience overseas prior to their ambassadorial or ministerial appointment. ${ }^{68}$

Businessmen and basically political appointments are reserved for special criticism by spaulding. They are nominated by the President and/or the Senate "because they like them or simply because they have the correct political backing," but seldom because "they know that they will be credible and effective representatives of Americans overseas." 
The tragedy of the system, according to spaulding, is that money and politics play a much greater role than the requirements of competent and experienced representation abroad. Yet, on the whole, "most of the big-money men' were able, and some of them became very good ambassadors." 69

Thomas A. Bailey, considered one of the deans of American diplomatic historians, also takes the position that amateur diplomats should not be excluded from consideration when it comes to making ambassadorial assignments. The basic premise of his primer for diplomats, The Art of. Diplomacy -The American Experience, is that the best diplomats "are born, not made." While they can learn from books and experience, "if they do not have the proper qualities of mind, character, temperament and personality, they are almost certain to fall short of completely satisfactory performance." 70 His contention is that while professionals might, on the whole, be preferable to amateurs, the latter have nevertheless made a generally good mark on American diplomatic history especially if (and when) they measured up to his crițeria regarding intelligence, integrity, dignity, tact, charm, discretion and patience. (Foreign language abilities, while desirable, are not essential for "if we must choose between the agile tongue and an agile brain, we must settle for the brain that makes use of interpreters. A fool who speaks Russian is still a fool." $)^{71}$

From his reading of diplomatic history, Bailey states 
that all embassies "are now significant outposts, and diplomacy is much too important to be left solely to the diplomats." Where overprofessionalization, overbureaucratization, overcautious diplomats of the striped pants variety dominate, then a "judicious leavening by talented newcomers has its place." 72

Bailey finds that, though the practice of appointing "fat cats" from the spoils system persists to some degree, in recent decades it has been increasingly reduced. Still, appointing prestigious men to prestigious posts and wealthy men to wealthy posts continues to have a role to play. Prestige adds to self confidence and might serve to impress the host government as a compliment to it. Personal wealth, in countries where the expense account is managed by a never overly generous Congress, remains in some cases as a necessity for bridging the gap between salary and allowances on one hand, and necessary expenses on the other. ${ }^{73}$

Some Criteria for Judgment

Having reviewed the many, varied; and often conflicting attitudes toward the question of career versus noncareer appointments to ambassadorial positions it is useful to extricate and summarize some of the criteria against which the success or failure of an administration's diplomatic choices can be judged, particularly in cases where a controversial appointment from the "spoils system" is made.

Four broad areas are worthwhile to look at: the cir- 
cumstances surrounding the appointment itself, the abilities (contributions) and the detractions of the nominee, the ambassador's record at his post of 'assignment, and the reception and reaction by the host country. Specific questions. include:

1. Motives for the appointment: What were the reasons of the administration for choosing a particular nominee for an ambassadorial position? Political pay off, exile or "out"? To "bump" an undesirable incumbent? To reflect a specific policy need? To provide a "dignified retreat" for a supporter?

2. Congressional Responsibility: Did the Senate adequately scrutinize the nomination? Did the appointee serve to improve Executive Branch relations with Congress?

3. Rezations with the President: Was the appointee's personal relationship an important factor in his nomination? Did the appointee "fall back" on his relationship with the White House during his tenure? Did the nominee adequately portray the administration's political position and philosophy to the host government? Did the appointee's own views sympathize with those of the administration? Did the nominee have a strong influence on the administration? 
4. Personal wealth: Was personal wealth a factor in choosing the nominee for a particular post and did his wealth serve to enhance or detract from his performance of duty?

5. Cultural abilities: Did the appointment have a knowledge of the conditions, history, etc., of his host country prior to his appointment? Did he know the language of the country? Was that a vital factor to his mission?

6. Private career: Did the appointee's private vocation contribute to the operation and major activities of his assignment?

7. Character suitability: Did the appointee reflect a high degree of character while ambassador ( $i . e$. , temperament, personality, intelligence, manner, interest)?

8. Representative image: Was the ambassador "representative" of the people of the United States, that is, did he serve as a reflection ("museum piece") of an average American citizen or of an elité class of society?

9. Relations with embassy staff: Did the ambassador utilize his embassy staff and to what degree? Did he serve as a "member of the team" or operate despite it? Did the ambassador command the respect of his staff? Did the appointee from outside 
the career foreign service ranks help to enliven the work of the professional staff serving him? Did he bring fresh ideas into the operation of the embassy? Outstanding talents not otherwise in the embassy staff? Was his leadership dynamic or passive?

10. Diplomatic skill: Did the appointee exhibit diplomatic skill, that is, was he adept at the conduct of diplomacy and negotiations with a foreign government? If experienced, was this a handicap? Was he "over-awed" by his hosts and fall into supporting their interests with unqualified admiration?

11. Respect and popularity: Was the ambassador able to gain the respect of his hosts? Did he enjoy a degree of popularity especially with the host officials in his country of assignment, as well as others?

12. Administrative and Zeadership abizities: Did the ambassador exhibit "professionalism" especially with regard to the suitable running of an embassy bureacracy? Did he exhibit executive abilities? Did the ambassador make decisions at the post or pass the buck to the State Department? Did the appointee have previous experience in government? Was he willing to take on difficult assignments? 
13. Political sensibilities: Did the appointee reflect good political judgment in assessing the problems of the host country? Did he maintain an objective stance? Philosophical detachment?

Stubbornly opinionated?

14. Reporting: Was the quality of the ambassador's reporting ( $i . e$. , perceptions, accuracy, conciseness, objectivity, etc.) considered adequate by the State Department?

15. Hast country reception: What was the quality of the welcome extended to the ambassador during his stay at post? How long a period of inquiry before the host country approved of a nominated ambassador? Was the appointment treated seriously by the host government? Did the ambassador relate well with the host government as well as with persons of an unofficial status?

16. Personal prestige: Did the ambassador's personal prestige add to his effectiveness as ambassador? Was the ambassador a "Somebody"? Did his performance enhance the prestige of the United States?

Plischke, in the introduction to spaulding's previously. cited book, has suggested it was relatively simple to assess the success or failure of a particular diplomatic appointee at the conclusion of his service, but it is quite the oppo- 
site case to determine either this, or even his ability or latent inadequacy, at the time of appointment. "Those charged with forging able careerists and appointing equally competent non-careerists to ambassadorial assignments bear a heavy burden of responsibility for the diplomatic future of the country." 74

Although hindsight does make for easier historical judgment, to render the most effective conclusions it is more important to look at the problems, advantages and disadvantages which existed at the time a diplomatic appointment was made and carried out.

As a case study for utilizing these criteria, it is appropriate to look at an appointment made by a Presidential administration which, despite its clear intentions to reduce the number of noncareer appointments in favor of the professional foreign service, still drew from the spoils system" in assigning amateurs to some of the major capitals of the wor $1 d$.

In 1928, four years after the passage of the Roger's Act which essentially established a career foreign service for the United States, Herbert Hoover's presidency seemed to represent the quintessence of leadership committed to the professionalization of government of the highest order and in the best interests of the people. Hoover, lacking the brilliance of a professional politician but nevertheless an able politician, was viewed as the most technocratic of 
American Presidents. He seemed determined to move in the clear direction of government by experts rather than amateurs. Yet, despite these ideals, Hoover still allowed amateurs to represent the United States abroad.

As a representative case study, the appointment of diplomatic amateur Senator Frederic Mosley. Sackett as Ambassador to Germany in 1930 is examined here. However, before fully understanding the Sackett appointment it is important to know more of those who bear the responsibility for making the appointment in the first place; to look at the conditions, philosophies, principles and practices -- in sum, to examine the environment in which the Hoover Administration was operating when it decided to send Sackett to Berlin. 


\section{CHAPTER II}

\section{THE HOOVER COMMITMENT}

It is symbolic that the day the thirty-first President of the United States was inaugurated was a cold and rain drenched one. On March 4, 1929 a "rain spattered" Herbert Hoover, in a somber inaugural address described as a "somewhat disappointing literary effort," spoke generally of the need to build up the "instrumentalities of peace" for a world which was then essentially at peace and to continue supporting maintenance of the means for the pacific settlement of controversies between nations. ${ }^{1}$

"In the creation and use of these instrumentalities," Hoover said, "we should support every sound method of conciliation, arbitration and judicial settlment." Yet, despite his own personal feelings, he insisted that the American people wanted no political engagements "which may commit us in advance as a nation to become involved in the settlement of controversies between other countries." In that same speech, Hoover made it clear American business was "very near his heart," and that he would give it as free a course as possible under his administration. ${ }^{2}$ In view of America's agreement to the Kellogg-Briand Pact of 1928 along with the world's major powers to outlaw war as an instrumentality for 
settling disputes, Hoover implicitly enhanced the position of diplomacy as the chief means for settling disputes between nations.

Such a promise warranted specific attention in Hoover's first State of the Union message to Congress on December 13, 1929 wherein the foreign relations of the United States was the foremost subject for discussion. In order to improve relationships and mutual understandings with nations -- especially Latin American ones -- it was Hoover's desire to utilize men with long experience in the American diplomatic corps "who speak the languages of the peoples to whom they. are accredited, as chiefs of our diplomatic missions in these states." 3 Free from the pressures of a political campaign, Hoover placed himself squarely on the side of the professional diplomat when he stressed the need for a stronger State Department to Congress:

The Congress has by numerous wise and foresighted acts in the past few years greatly strengthened the character of our representation abroad. It has made liberal provision for the establishment of suitable quarters for our foreign staffs in the different countries. In order, however, that we may further develop the most effective force in this, one of the most responsible functions of our Government, I shall recommend to the Congress more liberal appropriations for the work of the State Department. I know of no expenditure of public money from which a greater economic and moral return can come to us than by assuring the most effective conduct of our foreign relations. ${ }^{4}$

In Hoover's view, the "importance of able and experienced American diplomatic representation abroad had been neglected as a factor in preserving peace." He later boasted 
that before his administration was terminated he had reversed the trend in using Latin American postings as political rewards by promoting career men to 18 out of 19 countries in that area and by sending career men to 13 other nations. But these he considered "lesser posts" where men of "outstanding" stature would be hard pressed to go. Despite his commitment to the professional career man however, Hoover sent to the "five or six great countries" of Britain, France, Germany, Italy and Japan men from outside the Foreign Service; former Vice-President Charles G. Dawes, former Senators Walter Edge and Frederic Sackett, Governor W. Cameron Forbes, former Treasury Secretary Andrew Mellow, John W. Garrett and William R. Castle. These were men chosen from "outstanding citizens whose public service and personal distinction carried additional weight," but nevertheless were not professional career men. ${ }^{5}$ They were politicians, millionaires, Republican party supporters, businessmen, lawyers -- all patronage appointments.

The American Diplomatic Corps: 1920s Status Report

World War I created an acute problem for the American foreign service in that there were not enough personnel in its ranks to meet the increasing demands of a relatively young nation thrust into world leadership. ${ }^{6}$ In addition, because of the war, commercial matters became of increasing importance as the United States was transformed from a debtor to creditor nation -- from being an exporter of raw 
materials to an exporter of finished manufactured goods. After the war, as international competition became keener, American merchants turned more and more to their government for aid to secure not only government contracts, concessions, and loan agreements, but a modicum of protection for them as well. Basically, the demand was to open the world to the American economic market. ${ }^{7}$

When Warren Harding and the Republican Party recaptured the White House in 1921 the question of the status and role of the professional diplomatic corps was raised and, in light of the post war conditions prevailing at the time, the responsibilities of the corps were enlarged. Historically the party to favor professional diplomacy, and at the same time commited to government aid in the expansion of trade, the diplomatic service under the Republicans became "an important tool" in fulfilling this commitment. In addition, the new administration's opposition to American entry into the League of Nations left the diplomatic machinery as America's "only means of international communication." 8

Harding himself was elected by a majority large enough to free him from many political debts which could have been paid with ambassadorial postings. And although during his campaign he asserted that America's diplomatic appointments "should not be regarded as mere temporary results of political football in the United States," he still used the spoils system. But it was to the credit of the Department 
of State and especially Harding's Secretary of State, Charles Evens Hughes, a known advocate of the merit system for determining promotions, that the cause of the professional diplomacy was advanced further than ever before in American history. ${ }^{9}$

Largely due to the influence of Hughes, no career diplomats holding upper service positions before Harding's election were asked to leave when the new administration took office. In subsequent appointments, preference for career men was shown by Harding and, by 1922, over 35 percent of all higher posts were held by career men -- a proportion reached before only under the Taft Administration. Their posts were in all parts of the world and included three ambassadorships. Depsite some charges of partisanship in some appointments, "the public was generally satisfied with the administration's record"10

Hughes was distressed that he could not at the time do more for the career men. "The man who entered the Diplomatic Service," the Secretary told Congress, "with very few exceptions, had private means of support." And, "it is not a good thing for the Diplomatic Service to be recruited, even on a merit basis, exclusively from men of families of fortune." Yet the foreign service drew mainly from this elite source due in large degree to the inadequate salaries paid to career men of the corps. ${ }^{11}$

It was during the Hughes tenure that the momentum be- 
gan toward getting legislation to improve the lot of the career foreign service and it remained for Calvin Coolidge to sign into law the reform Rogers Act of 1924 -- with nonpartisan backing in Congress -- which substantially raised the status and salary of the career foreign service offi$\operatorname{cer} .^{2}$

When Hughes left office in 1925, nearly 40 percent of all upper service posts, including a third of the ambassadorships, were held by career men. For the rest of the decade, dominated by Republican administrations and politics, the cause of professional diplomacy in America was advanced as there was an increasing reliance placed upon career men. ${ }^{13}$ Mainly because of the President's disinterest in foreign affairs, his Administration placed a great deal of control for foreign policy in the hands of Secretaries of State, Hughes and Frank B. Kellogg. Of the 25 appointments made under Coolidge, 15 were given to career men and, by 1927, over 45 percent of the major posts were in career hands. ${ }^{14}$

The pressures for the elevation of the status of the foreign service did not end in 1924, and an incident occurring in the midst of the election of 1928 was significant in demonstrating the growing self-assured assertiveness of the career personnel during the period. Just prior to the election a score of career men in ambassadorial and ministerial posts decided to break with precedent and not submit their 
resignations to the new President after March 4, 1929. A few political appointees were also taking this attitude but most were those who had come up through the ranks of the diplomatic and consular services who disliked the idea of being deprived of their posts in order to make room, possibly, for political appointees, or at least being demoted to secretaryships if no ambassadorial or ministerial positions were open to them. According to the New York Times, "Any move by foreign service officers to remain in their posts would be regarded as startling, and would doubtless provoke a storm of controversy in Congress." 15

Secretary of State Kellogg asserted that the administration's position that the "career men" were still personal appointees of the President, as were all the top officials in the State Department. "Governmental circles" began to argue that Congress should create a grade of minister "to which career diplomats could be appointed whether on assignments abroad as resident plenipotentiaries or not," as this would mean professional diplomats would not have to be terminated as a result of an administration change nor would they have to resign from the foreign service when appointed to an ambassadorial position. Kellogg argued that the state Department never looked into the politics of a man in the foreign service when it wished to appoint a minister, and, besides, it was hard to get qualified men for top posts within the service due to lack of funds and an inability to 
pay adequate salaries. ${ }^{16}$

It remained for "silent Cal" Coolidge to assert the power of the Presidency over the appointees in this, the most serious breach in the hitherto constructive relationship between the Executive and the professional foreign service officers. Coolidge rejected the notion of the career men not resigning claiming their action was "unconstitutional and savors of an attempt to set up a self-perpetuating body." Such an action, he pronounced, would be highly irregular and not in accord with long standing custom. The appointees were the representatives of the President in carrying out his instructions and policies and that if they did not resign the President had the power to remove them. ${ }^{17}$ Perhaps out of regard for avoiding disagreement with his chief, Secretary of Commerce and Republican party nominee for the Presidency, Herbert Hoover, did not speak out on this issue during the 1928 campaign, despite his indications of support for more professionalism in government. But once assured of the office, Hoover became the most outspoken president in favor of the advancement of the professional diplomat. His favoritism for professionalism per se, however, would be tempered not only by the economic conditions of the world during his administration but by his own predilections for business politics as well.

The Hoover Apprenticeship

After Hoover's inauguration and soon after his appoint- 
ment of Henry L. Stimson as Secretary of State, the entire State Department personnel from the previous administration was retained without acceptance of the resignations which came from all ranking officials including ministers and ambassadors. However, given Hoover's "definite ideas about improving that branch of government," a considerable shakeup in the foreign service was taken for granted by the press and expected in the state Department. ${ }^{18}$

Both President Hoover and Secretary Stimson would be noted for sustaining the progress of the career foreign service during 1929-33 such that by the end of their term in office, 51 percent of the upper service posts -- including nearly half of the ambassadorships -- would be filled by professionals. ${ }^{19}$ This trend towards professionalism in Hoover's thoughts had been gaining ground beginning with his own observations of the conduct of American diplomacy right after World War I, continuing throughout his term as Secretary of Commerce during the 1920s, and perhaps culminating in his outspoken pronouncement after his Latin America tour to appoint more career professionals to high diplomatic posts in that region.

In his memoirs, published in 1951, Hoover recalled his impressions of the post World War I period when balance of power politics and military alliances continued as a "national necessity" for the major nations in Europe. The United States, however, was ill-adapted or prepared to en- 
gage successfully in these practices or even understand them. The whole system of American government with its "shifting administrations and policies" prevented the United States from developing experienced personnel which could comprehend and deal with the complexities of European politics. "With our changing elections," Hoover wrote, "we can never have the continuity in foreign policies upon which such men could act with assurance in these fields, if they did know." Further, if confirmation of American naiveté in politics was needed, one "needs only to analyze our group of peacemakers who, with little experience in foreign affairs, worked in a sort of daze over the forces they met at Paris. ${ }^{20}$ Despite America's alleged inability to deal on a par with European diplomats, as Secretary of Commerce, Herbert Hoover was convinced of the desirability of America taking advantage of foreign investment opportunities. The resources of his department were mobilized to awaken American businessmen to these opportunities and to aid those who were "willing to participate" in foreign economic activity. ${ }^{21}$ Hoover maintained a conviction that American investors "deserved" their government's guidance. ${ }^{2} 2$

Hoover continued gradually to develop a distaste for direct political involvement in European affairs. Although he tried to be realistic about America's prominent and growing role in world affairs (he originally supported American entry into the League of Nations) his disillusionment with 
the conflicts in Europe, the horrors of World War I which he saw first hand while serving as Chairman of the Commission for Relief in Belgium and as Director of the Federal Food Administration during the Great War, and with the bitter battle over the Versailles Treaty, caused him to fall back on reaffirming the ideology of American nationalism. ${ }^{2} 3$

As Secretary of Commerce, Hoover built up an amazingly effective force of commercial attachés working abroad almost totally independent of the regular foreign service. Hoover's own "foreign service" in Commerce proved more competent in the surveillance of American business interests and opportunities, a relatively new mode of foreign work for which the regular diplomatic corps seemed ill-trained to perform. This activity was the source of constant friction between Commerce and State, at least at levels below the secretaryships of each department. Under the Rogers Act of 1924 general jurisdiction over all American governmental activities abroad was placed under the Secretary of State. However, Hoover's attachés proved quite adept at working outside the eye of the local embassy. This contributed to Hoover's idea that the regular diplomatic corps, though seemingly professional in the ordinary modes of diplomacy, required effective training in order to meet the needs of the modern world of the 1920s. ${ }^{24}$

Beyond the perceived need for a professional foreign service to work in the complexities of post war international politics, much of Hoover's foreign policy views were formed 
during his years as Secretary of Commerce and, not surprisingly, many had an economic bent but with a decided distaste for official political involvement on the part of the United States. Hence, Hoover was most actively involved in the encouragement and benign supervision of private sector loans to the nations of Europe (and especially Germany) as an acceptable means for aiding in the reconstruction of the European economy which, he believed to be closely involved with America's.

The war debt and reparations issues caused a lot of bitterness among Europeans toward America, mainly due to the terms under which American assistance was offered. Perhaps the most severe American government qualifications for loan approval was that of concluding war debt agreements with the United states first before any substantial loan assistance would be encouraged. As Secretary of Commerce, Hoover exerted a dominant influence in implementing the government position on war debts. Earlier, in 1922, while Hoover was a member of the World War Foreign Debt Commission, he proposed cancellation of pre-armistice debts. Yet as Congress and perhaps American public opinion was against such an idea, it was dropped. As the British and French mounted a propaganda campaign for cancellation and asserted. that American failure to guarantee the payment of German reparations and other financial obligations were aggravating the international transfer problem, Hoover became more insistent 
upon separating the questions of debts and reparations altogether. ${ }^{25}$

Eventually a major principle in Hoover's loan policy was to discourage further loans to debtor countries who failed to strive for balanced budgets and economic stability. Hoover's initial policy toward Germany during his years in Commerce was to encourage private sector loans from America with the sanction of the United States government in the hopes that financial recovery could be spurred without threatening the reparations plans worked out under the Dawes Plan. As long-term observation determined increasing dangers of default on loans to German industries, Hoover pressed for closer governmental supervision of these private sector loans. But with the private sector calling the shots, there was little real control exerted.

According to economic historian Joseph Brandes, neither Hoover "nor Hughes and Kellogg, certainly not Mellon were willing to appear in a position of curbing American enterprise. Hoover, it is probable, hoped that American bankers would make the right choice voluntarily..."26 Yet, in the 1920s there were considerable speculative excesses and Hoover's inability to exert stricter controls over the loans to Germany while he was Secretary of Commerce perhaps also reflected limitations of his own influence in a Republican administration.

Hoover was intensely concerned with the Latin American 
region as a "huge market" for American products and as a source of raw materials and under his auspices an official corps of experts on Latin American economic affairs was developed within the Commerce Department. ${ }^{27}$. Over the question of loan standards to Latin America Hoover was often at odds with the State Department. His belief that loans should be on a "business basis" rather than enforced via "dollar diplomacy" and because he opposed use of military intervention and/or non-recognition as forms of pressure seemed to contradict the long standing policies practiced since the Wilson Administration. 28

Brandes has asserted that American public opinion was turning away from the direct extension of political influence in Latin America along the "old lines of dollar diplomacy" and that Hoover's emphasis on policies "justified the economic interest of the entire hemisphere" and, unencumbered by political considerations, they gained favor in post war America. Frowning on the use of "coercive measures" Hoover felt more government supervision of investments, particularly before they were made, was required. Hoover did not sanction armed intervention, preferring instead "the pragmatic bargaining of the international market place." 29

Hoover has reinforced this thesis himself. Dissatisfied with American "dollar diplomacy" attitudes by threats and intimidation on behalf of speculative citizens when their investments went wrong, and especially dissatisfied over the 
character of American loans in the area, Hoover declared that "American citizens venturing their capital and energies in these states were doing so at their own risk, and that our interventions on their behalf if they were unjustly treated would be purely moral representations." 30 Hoover. believed the best preconditions for a loan were to consider countries who balanced their budgets, refrained from requesting unnecessary or unproductive loans, and eschewed armaments and warfare. This counsel was expressed not only to Latin American nations, but to the great powers of Europe as well.

The President's Policy

Once safely ensconced as president-elect, Herbert Hoover journeyed to several Latin American countries largely to demonstrate to the south-of-the-border nations "an entirely different attitude" that his administration would take toward that region. Hoover regarded improvement of relations in Latin America as "especially vital, for it seemed to me that in the future outlook of the world, we in the Western Hemisphere not only shared mutual interests, but common threats to those interests." He wanted to emphasize a new policy -- good neighborliness -- and one of the concrete results of his visit was a commitment to improve American diplomatic representation in the area.

"During my journey I had the opportunity to observe the character of our Ministers and representatives," Hoover 
later wrote. "Some of them were 'career' men doing magnificent service. But some were political appointees who were eyesores to the countries to which they were accredited and to us. I determined that we must reorganize the whole service." 32

This, he considered, was one of the achievements of his Latin America policy; the removal of political appointees from his own party's administration as ministers and ambassadors and the sending to each post a professional "or otherwise independent person who had a background of experience and a familiarity with the people, their language, customs and culture." ${ }^{3}$ Certainly no other Chief Executive before Hoover had made as strong a commitment toward the professional diplomat.

In early 1929 there was no great pressure on Hoover to make hasty appointments to the diplomatic posts around the world. With time for reflection on the matter, the New York Times speculated that, due to Hoover's interest in developing foreign trade relations, men more familiar with business affairs than were "nine out of ten professional diplomats" would be sent into the field. "That this can be. done is clear from the work of the Commercial Attachés. They have combined political and social contacts with a proper regard for economic interests." 34 But in a short while the New York Times reported the White House would make "few changes of major importance." Many of the appointments in 
Europe, made previously by Coolidge, were carried over for a time and, for the then vacant posts in London and Paris, career men were not suggested for posting to these. Instead the Times suggested that in choosing ambassadors for these, men with "personal weight and attractiveness of character, together with representative quality not required by law but demanded by an old and honorable tradition," combined with diplomatic propriety and expertness be sent to London and Paris. ${ }^{35}$

Aside from drawing upon the business and professional world, particularly for Europe, it was nevertheless understood Hoover would make better use of experienced foreign service officers and "encourage their natural desire for advancement." Assignment of political appointees, except in some notable instances, would be to countries where their reputations would be an asset and the "handling of economic questions through diplomatic channels will not require the training which the permanent foreign service is supposed to give." Career men, the Times stated, should go to the more demanding posts -- Latin America, for example -- where the furthering of America's "material interests" in areas where the "best opportunities" existed for the extension of American business. ${ }^{36}$

Hoover's promise to strengthen United States representation in Latin America made sense as it would provide an opportunity to show if the "career men" would be up to the 
task of furthering American material interests. It was clear to the Times that Hoover was not impressed with the foreign service due in large part to the growing differences between the Departments of state and Commerce when the President was Secretary of the latter.

But nothing has appeared to indicate that, whatever feeling the commercial attachés of the Department of Commerce may have had, and have, against the career men of the State Department Foreign Service, it will influence Mr. Hoover now that he is President in dealing with our diplomatic representation abroad. Instead, the career men are to have the opportunity ... to test their ability as business agents for the United States. ${ }^{3} 7$

Nevertheless, in Latin America and the Far East, all major posts (with the exception of one) went to professional career men, prompting two of Hoover's contemporaries to write that the United States gained "a Foreign Service of the first rank. Never in our history was peace more assured to the American people or did the United States stand in higher esteem of the world than on March 4, 1933," when Hoover left the White House. ${ }^{3} 8$

Despite the gains of the foreign service in the 1920s, the New York Times' diplomatic correspondent noted that morale in the service, by 1929, was at an all time low. Inadequate salaries still prevented many from going to the top posts (and hence most of the ambassadors in the grander posts still had to be men of private means). Resignations within the service began to increase as officers saw little in the way of a future with the state Department. "Some of this 
reported dissatisfaction is due to a continuation of the practice of giving most of the outstanding Ambassadorships to noncareer men." 39

Since the State Department was identified as Hoover's foremost "Instrumentality of Peace," both he and his Secretary of State, Henry L. Stimson, actively sought to strengthen it. With additional Congressional increases in allowances for the top echelon positions, it became easier to place career men without private incomes into ambassadorial and ministerial positions in most areas of the world. ${ }^{40}$

The Stimson Influence

No less than his predecessors -- Hughes and Kellogg -Secretary of State Henry L. Stimson depended greatly on his personnel in Washington and especially in the field. ${ }^{41}$ As the number two spokesman for American foreign affairs, and perhaps the most predominant spokesman after President Hoover became engulfed in the problems of the deepening Great Depression, Stimson attempted to control as much as possible, the appointments to the top echelons in the state Department. ${ }^{42}$

When Stimson took over the State Department he was barely known by Hoover who had selected him on the basis of his reputation as a loyal party man with a keen sense of foreign affairs, and even then only after both former secretary of State Hughes and Senator William E. Borah had de- 
clined the job. Although Hoover and Stimson would have sharp disagreements over policy and action -- frankly admitted to in their respective memoirs -- Hoover would later compliment Stimson for his "integrity of character, his loyalties and his long experience in public affairs" as having been a "contribution to American Iife in its best sense." The Secretary, Hoover stated, "was a man of integrity, sagacity, loyalty, and patriotism, as befitted that office."43 However, when he came in 1929 to take over the State Department, Stimson felt this was the one assignment of all his years of public service for which he was least prepared. ${ }^{44}$

At the top echelons stimson assembled one of the most highly regarded and capable "team" of policy officers ever seen at the state Department up until that time. Relying much on the experience of others, Stimson retained the major assistant secretaries from the Kellogg period and added several prominent new members drawn from professional businessmen, lawyers and economists with experience in some form of foreign affairs. ${ }^{45}$

Yet, as time went on and America entered the throes of the Great Depression and as the problems of the Hoover Administration grew, stimson found it difficult to get private citizens of "standing and ability" to help him at the State Department. The series of refusals Stimson received was indicative of the preoccupation of "able men" (especi- 
ally after 1930) with their own affairs. Stimson would later write that, at the time, "the needs of the nation, and the world, were given second rank." 46

As for the placement of representatives in the field, Stimson became a most ardent supporter of the professional career man's promotion to ambassadorial and ministerial positions in most areas of the world. In that the chiefs of mission in the Latin American nations were mainly career officers, Stimson credited Hoover's promise to strengthen the diplomatic service in that area. But he also realistically knew career men went there because "the men who had earned political rewards were not ordinarily eager to serve in Latin America." 47

Stimson felt the view of many Americans in 1931 "to assume that their foreign service does not match that of other nations," was wrong. He saw that the career officers of the State Department both in Washington and abroad as executing their assignments "with their accustomed skill and devotion." The critical events in Europe and the Far East during 1931-33 reinforced Stimson's conviction "that American professional diplomats were at least as good as any in the world - their difficulty was that their country seldom supported them with effective policies."148

Unlike Hoover, Stimson did not speak in terms of the desirability of appointing noncareer men of distinction to the major world capitals. Yet in view of his Republican 
partisanship and his own career, it is unlikely that stimson did not support Hoover's opinion that men of distinction should be sent to the greater posts of the world. What is important to understand is Stimson's general philosophical attitude which indicated perhaps more a preference for allowing the conditions of the time and the demands of the specific job to determine the desired qualifications of an individual needed to meet the challenge. His philosophy harkened to Wilsonian morality wherein public opinion could be depended upon to support righteousness in world politics. Honest diplomacy backed by the decency of mankind would make for wonderful relations with everyone on the international scene. ${ }^{49}$

As the Great Depression settled over the United States during the 1930s, American public opinion lost its purity of cause and demanded that the great major powers of Europe pay their war debts lest "the American taxpayer, who had troubles of his own, would have to pay."50 Stimson, forsaking philosophic idealism for economic pragmatism, felt it best to cancel the obligations outright but Hoover, more vulnerable to the American public, continued to feel that they should be repaid. German reparations, Hoover insisted, were not to be related to the debts owed by the Allies. But the German economy remained of vital interest to the United States due to the extent of the huge loans made by private American bankers. If these loans, bad as they might have seemed to 
Hoover, were jeopardized any further, then the world-wide Great Depression would mean greater catastrophe for America's own sagging economy. ${ }^{51}$

In Europe the challenge to American diplomacy was seemingly clear. But did American diplomats measure up to that challenge?

The Context For American Diplomacy Toward Europe in 1930

In general, the Hoover Administration closely reflected American public opinion, at least as far as foreign policy attitudes were concerned, even after the Crash of 1929 and entrance into the Great Depression. The mood of the country throughout the 1920s seemed, for the most part, against a policy of extensive world commitment as "the immense prosperity of the United States concentrated American attention on domestic rather than foreign affairs." Plus, neither Harding nor Coolidge were leaders in the realm of foreign affairs, in large part because the former was basically intellectually mediocre while the latter was "incapable of powerful or effective leadership." Hoover, on the other hand, was not like his predecessors. ${ }^{52}$

A major historian of the period, Robert H. Ferrell, has described Herbert Hoover as "one of the most learned and capable men ever to rise to the presidency. In sheer mental power, in administrative ability, the thirty-first President of the United States has had few equals." 53 His experience in foreign affairs was superior to stimson's and 
he was, according to Ferrell, "the best-traveled American President" since John Quincy Adams. Unfortunately Hoover was to become a victim of circumstances effectively beyond his control. By late 1930, the Great Depression had swept over America and Western Europe casting with it a "depression psychosis," a loss of self-confidence and a "timidity of statesmanship" on the part of nations which even Hoover could not overcome. ${ }^{54}$

Hoover strongly believed the "Great" Depression did not really start in the United States until after the European economic collapse. Economic failures in many countries, particularly Germany, were responsible for the economic crisis which pulled the vulnerable American stock market down in October, 1929. Europe was "the great storm center" which "burst into a financial hurricane" after the spring of 1931 as a direct result of the economic consequences of World War I. Although he was certainly alarmed over the "growing tide of speculation" and inflation of credit during the 1920s, Hoover believed the first 17 months after the Crash did not constitute a major depression and was instead a mere recession and that even during the first three months of 1931 the American economy was beginning a strong convalescence. The Crash itself, he felt, was but a salutary readjustment of the economic system. External influences, Hoover believed, cut that recovery short. ${ }^{5}$. This attitude, plus the belief that the "rotten banking system" contributed 
to the economic malaise, as Ferrell points out, explains much of the policy towards Western Europe during the remainder of the Hoover Administration. ${ }^{56}$

When Hoover took office in 1929 he mirrored public sentiment by serving as a "business" administration and in this he inherited much of the traditional Republican foreign policy to which he had himself significantly contributed during the 1920s. Throughout that period the Republican leadership sought to enlarge America's economic superiority in the world while at the same time creating a favorable political climate to reinforce its economic opportunities. They believed superior management techniques would help them achieve their economic goals without any substantial political or economic cost. Political commitments were to be avoided, a signal made clear from the start of the Harding Administration. Insofar as economic issues were concerned, the basic Republican posture was to avoid them on an official level while at the same time supporting assistance to Europe in a private sector capacity. ${ }^{57}$

Initially, American foreign policy under Hoover, while not necessarily vying for economic predominance, pragmatically sought to promote European stability and American selfinterest. When the depression struck, the dilemma became a frantic attempt to accomplish this aspiration short of directly involving the United States in the political and territorial controversies of Europe. In the midst of the 
catastrophe Hoover held economic factors as primary in both national and international affairs. But like it or not, as Stimson stated, the United States could no longer lead a "life of isolation" from its neighbors as it had during the 1920s become too dependent upon the rest of the world for its trade and commerce. America, he said, had become the champion of the "commercial and non-military stabilization of the world." 58

American officials, bankers and businessmen turned their attention on the economic and financial aspects of international problems and tried to resolve them through the use of "experts," the application of "business methods," the mobilization of private voluntary cooperation from within the financial community, and the subordination of political factors in order to meet the perceived economic and world peace challenges faced throughout the 1920s. ${ }^{59}$ Despite the depression, this faith in economic expertise and business methodology held by the Republicans was not shaken.

Throughout the 1920s American foreign policy makers recognized the importance of restoring European economic stability in general and of specifically resolving the Franco-German problems in order to insure America's own economic stability. In view of prevailing American public opinion, financial leverage via the private sector was the best alternative available and culminated in the Dawes Plan of 1924 and later the Young Plan in 1930 wherein American 
loans were held as bait to gain acceptable reparations accords and debt settlements as well as forces to curb inflationary practices and incite the balancing of European budgets. Yet political aloofness, at least superficially, was maintained, as exemplified by the co-opting KelloggBriand Pact which enabled the United Stated to avoid a direct role in the collective security programs on the Continent. ${ }^{60}$ Nevertheless, by August, 1931, America's activities in Europe were so extensive that the Journal of the American Banker's Association declared that "the last vestige, the last pretense of following Washington's advice to avoid European entanglements [has been] thrown aside ... Our isolation is at an end, we sit in the seats of the mighty ..." 61

In the view of many Republican policy makers the entire program for European as well as American economic and political security rested upon the "existence of a prosperous, republican and contented Germany." Hughes believed that "there could be no economic recuperation in Europe unless Germany recuperates." Most Americans, whether businessmen or farmers, and whatever their political feelings, agreed that prosperity in Europe depended upon Germany's economic recovery. ${ }^{62}$

In the period after World War I, the German Government seemed somewhat grateful for American financial assistance and actively sought to encourage American good will. Their 
first ambassador to the United States after the war reflected a sympathy for business pragmatism and was chosen to further a close economic relationship and because it was felt he could get along well with the big-business mentality seemingly prevalent in Washington and interest America in investing in the Weimar Republic. Other successive German ambassadors sent to Washington worked to protect Germany from excessive political and economic demands emanating from France. ${ }^{63}$

At the same time, Americans seemed happy to invest in Germany and this investment wielded unofficial political advantage and aided in attempts to promote a short-lived Franco-German rapproachement. ${ }^{64}$ However, America's total relationship with Germany by the 1930s was nevertheless extremely limited in that successive Republican administration policy makers, including Hoover, continued to treat economic and political relations with Germany as separate matters thereby making a total aid package to Germany impossible. The Americans were "hesitant and timid" in pursuing economic diplomacy on an official level as they were committed to free enterprise principles and encouraged aid only from the private sector. ${ }^{65}$

Just how limited American policy was became evident in the inability of the Unted States to assist the European powers to stabilize their economies and to deal effectively with the immense national security problems involved. This is not to say the United States could have dealt with such 
problems; rather, the extremity of American policy not to become involved in European conflicts that did not relate to vital American interests severely restricted America's ability to interact on even a diplomatic level. American leaders realistically knew they could not resolve the "incendiary issues" separating France and Germany. Recognizing that "lasting peace depended upon mutual accomodation," the United States did not or could not forcefully move beyond the 1928 Kellogg-Briand Pact or the London Naval Conference of 1930 in attempting to resolve the issues involved until the spring of 1931 when Hoover belatedly became aware of the critical financial situation in Germany and announced a moratorium of war debt settlements. By late 1930 it was, perhaps too late for the Hoover Administration to do otherwise. ${ }^{6} 6$

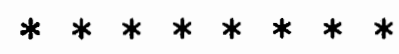

It is within this historical context that an analysis of Hoover's ambassadorial appointments to European embassies must be made. Despite the pressing demands thrust upon the United States (especially by France, Germany and Britain), demands which would seem to require the best of American diplomatic expertise and professionalism, the President sent men from outside the professional foreign service to interact on his behalf with the critical policy makers in Europe. This is not the only backdrop against which the drama of diplomacy in the 1930s was played for in the short span of 
time since the Great War the entire stage for the conduct of diplomacy had changed. Technological advancements in communciations enabled greater control over diplomacy by the policymakers at home thereby bringing their influence on issues to a higher level than ever before. The growing comlexities of economic change and expanded private business activity forced governments to be more responsive to a larger constituency within their own borders now interested in the conduct of foreign affairs. And by virtue of the spread of democracy -- albeit fragile in most cases -- new challenges were offered to the traditional forms of diplomatic conduct including a direct threat to the once cherished aspect of secrecy in affairs. ${ }^{67}$

Wilsonian idealism was not simply cast aside in the period following 1920 despite America's seemingly inward turn away from international involvement. Rightly or wrongly many believed that one of the causes of the Great War lay in the failure of a sinister kind of "secret diplomacy" and that if future conflagrations were to be avoided and American security protected a "new diplomacy" with new techniques and methods to satisfy a democracy was still demanded in the period. ${ }^{6}$ Clearly, America recognized inadequacies within its own foreign service. Forced into relying upon diplomacy to a greater extent than ever before, the United States after World War I undertook unprecedented expansion and the reinforcement of its state Department. 
Not only were more capable men enlisted, a heavier reliance was placed upon professional career men in the field and more of them were sent to bolster American diplomatic posts abroad.

Towards a more professional American diplomacy was a policy goal held not only by political administrations in power but an ideal genuinely held by the American people as well. Yet a concurrently held faith was in the ability of the wealthy citizen to play a meaningful role in the service of his country; that in a democracy, such as that in the United States, all citizens, if capable, could serve to foster the image of their country's liberalism whatever his professional calling might be. This is not to say that one ideal necessarily contradicts the other for Americans have always held a high regard for professionals in all walks of life. But it also seems that Americans have retained a streak of skepticism about placing total and unchecked control in the hands of experts.

Idealism is one thing; political practicalities often prove to be quite another. With this in mind it is worthwhile to examine one ambassadorial case in point wherein the Hoover Administration, professing a commitment to place professional diplomats in top level posts, sent to Germany a political appointee having little or no experience in diplomacy.

The question then, as now, is more complicated than 
simply asking were amateur diplomats, as ambassadors; so bad? An examination of one such political appointment from outside the foreign service, that of Frederic Mosley Sackett who went to Germany on behalf of the Hoover Administration and the United States in January, 1930 will help shed light on the questions raised. A successful businessman-lawyer, United States Senator, Republican party partisan with strong ties to the Hoover candidacy in 1928, and having no real experience in the workings of American diplomacy, Sackett seems to fit into many of the stereotypes commonly tagged on to the amateur appointment from the "spoils system" especially at a time when his own elective position in the Senate seemed jeopardized. 


\section{CHAPTER III}

\section{A CASE STUDY: AMBASSADOR FREDERIC MOSLEYY SACKETT'S ASSI GNMENT TO GERMANY}

When a new Presidential administration publishes its diplomatic appointments list at the start of its term, little criticism is characteristically voiced over the professional career men who are selected for ambassadorial or ministerial posts. It is usually assumed that since they are professionals there is little place for critical judgment over their competency or ability to perform their assignments. More attention, however, is reserved for those assigned from the noncareer ranks; men and women who may have little long term affect upon the nation's conduct of foreign affairs but who, for the time that their administration is in office, receive a disproportionate amount of attention.

Perhaps, too, their noteriety stems from the location of their assignments. In recent years America's diplomats in Moscow, Tel Aviv and China have seemed more pivotal to the conduct of American foreign policy than those in the European capitals. But in 1928-33 Americans looked primarily to London, Paris, Berlin and Rome as the central locations of world leadership, the capitals where the real power 
and the control of destinies were held; hence, anyone appointed as ambassador plenipotentiary to these posts was inevitably singled out for special attention, both by contemporaries and later by historians of the period.

In choosing Herbert Hoover's ambassador to Germany, Frederic Mosley Sackett, as a case study for this exercise it is interesting to note that; for the most part, historians dealing with the broad story of America's role in European affairs in the period between wars have been largely indifferent to his role in the events which passed at the time and his influence upon them. Even in the rare cases where statements on Sackett are made, their superficiality indicates more of a slight-of-hand pass over of Sackett without any real scrutiny of his record as ambassador nor of how he came to get that assignment in the first place. In general, contemporary comments of Sackett's job as ambassador are overlooked. Evaluations of his record are tied to the harsh judgment that since America's foreign policy toward Europe at the time failed, Sackett's ambassadorship was a failure as we11.

In The Origins of the Second World War, Arnold Offner called Sackett "a very poor analyst of the political scene" who spent much time encouraging American investment in Germany and who became a "sympathetic, if sometimes indiscreet" spokesman for Germany's Weimar Government "in its battle to end reparations." In addition offner has asserted that 
Sackett saw little reason to worry over the turn of events in Germany which eventually led to Hitler's installation in the seat of power in Germany. Offner has reinforced this assessment of Sackett in other writings without really citing specific primary evidence to adequately support his' judgments. ${ }^{1}$

Other critics have chastized. Sackett more for the background of his appointment than for his performance in the events while assigned to Germany. No less than his colleagues in London, Paris and Rome, Sackett appeared to emerge from America's peculiar form of spoils rewards. Historical commentator on the Department of State, Graham $\mathrm{H}$. Stuart, summed it this way:

The appointment of Senator Frederic M. Sackett as ambassador to Germany was perhaps most deserving of criticism because of his complete lack of experience in international affairs. But here too, it could be argued that $\mathrm{Mr}$. Sackett was a very successful businessman who had proved his ability in the public service as Federal Food Administrator for Kentucky and a man who was capable of improving our trade relations with Germany. Furthermore, since Dawes, Edge and Sackett had all been good friends in the Senate, they would be inclined to cooperate in carrying out their duties abroad. ${ }^{2}$

Perhaps the most even-handed assessment of Sackett is in Edward W. Bennett's Germany and the Diplomacy of the Financial. Crisis, 1931. Bennett views Sackett as having been decidedly pro-German and preoccupied with the "dangers of communism" and being more or less a puppet used by German Chancellor Heinrich Brüning and his foreign minister. The latter believed he had Sackett in his vest pocket, and both 
believed Sackett was politically nä̈ve. "Certainly Sackett was favorably inclined to Germany, "Bennett states, "although he did not always report as the Germans expected him to." Perhaps Bennett underestimated Sackett's influence in encouraging American responsiveness in the German financial crisis, but he at least gives the ambassador a fair hearing on the basis of historical evidence before making his judgments. ${ }^{3}$

The object of Chapter III of this paper is to describe in some detail, and in the context of the time described in Chapter II, the background and political career of Frederic Sackett and to closely scrutinize the circumstances of his appointment as ambassador to Germany. Significantly Sackett's performance as ambassador and the assessment of his job by his contemporaries are considered with emphasis placed upon Sackett's ability as a nonprofessional diplomat as well as his role in the specific events accurring in the Weimar Republic at the time. " This is done with a view towards judging Sackett's record against the criteria established in Chapter I.

Mr. Sackett Goes to Washington

The political career of Frederic M. Sackett began in the midst of the business oriented 1920s. The ascendency of the businessman essentially began during World War I when an "army of businessmen" many of whom were trained in professional business schools, went to Washington to help 
President Wilson administer "the greatest government operation in the history of the century," as the nation mobilized to participate in the fighting of the First World War. Later, in the nation's attempt to "return to normalcy," business interests found friendly receptions on the part of the Harding and Coolidge Administrations. Coolidge especially changed both his administration and the Republican party into a "businessman's government" wherein all prosperity rested upon business leadership. ${ }^{5}$ In a world for the most part at peace, the growing movement to insure the continuation of peace was significantly supported by business interests inside the United States. ${ }^{6}$

In this atmosphere it is not surprising that wealthy businessman Frederic Sackett was elected in 1924 on a Republican ticket to serve the State of Kentucky in the United States Senate. Sackett easily won his primary nomination for the position and based his successful campaign on his appeal to businessmen. ${ }^{7}$ Although not a native son of Kentucky (he was born in Providence, Rhode Island and was a graduate of Brown University and the Harvard Law School) he had married into a wealthy Kentucky family and quickly established himself as an activist in Kentucky affairs. Sackett served as president of the Louisville Board of Trade in 1917 and again in 1922; was appointed Federal Food Administrator for Kentucky working with Herbert Hoover during the war years; was a member of the Kentucky State Board of Charities 
and Correction from 1919-1924; and was director of the Louisville branch of the St. Louis Federal Reserve Bank until his election to the Senate in 1924.

Soon after Sackett married the former Olive Speed in April, 1898, his business successes made him financially comfortable. However, he continued to pursue business interests and in the course of his career was president of the Louisville Gas Co., the Louisville Lighting Co., the Pioneer Coal Co., and Black Star Coal Co., and was vice-president for the Jellico Coal Co., and the Louisville Cement Co. In addition to these, he worked as director for the Fidelity and Columbia Trust Co., and the American Tar Products Co. After his 1924 nomination victory in the Republican primary, the Louisvilze Herald Post commended the Republicans for putting forward "the best man that party has available." Later, when Sackett won his Senate seat, the same paper noted he had received considerable support from independent voters in the state "who admired his character and ability." Although the newspaper regretted the defeat of the Democratic candidate in the election, the Herald Post felt Sackett would make a good Senator despite the fact he was a "rock-ribbed conservative." In March, 1925 the Herald Post editorialized that Sackett would be acceptable for he at least "looks the part" and was "broadminded," with various experience, knowledgeable of public affairs and eminently successful. Sackett, despite his origins in New England, was a "wholly 
satisfactory and representative Kentuckian of the modern type, the type that does things rather than the type which talks, very beautifully, of past things done." 8

Sackett's Senate career was rather lackluster. His most significant committee assignments during his six-year term were essentially business oriented: Banking and Currency, Interstate Commerce, Commerce and, in his, last two years, the influential Finance Committee. But given the atmosphere of most of the 1920s, these committees played merely a support role for Republican administration policies emanating from the White House -- mainly that of non-interence in business affairs - and Sackett's own role, perhaps due to his own intended low profile and short experience in the Senate, was a minimal one. Only after the Depression and the consideration of the Smoot-Hawley Tariff got underway did Sackett play a slightly more active role. However, Sackett's record shows a more active participation in the affairs of one relatively minor committee, that of the District of Columbia which concerned itself mainly with road improvements in the capital city. ${ }^{9}$

For the most part, Sackett spent his time in the Senate defending the interests of his state's coal mining industry especially insofar as interstate coal transportation rates and the protection of Kentucky's favorable rate status were concerned. Otherwise Sackett made few significant statements in the Senate until April 20, 1928 when he undertook the de- 
fense of Secretary of Commerce Herbert Hoover (then running for the Presidency) against "partisan attacks" in the Senate over charges that during Hoover's tenure as Federal Food Administrator he had engaged in price fixing against the interests of farmers.10

Perhaps the only real public commotion stirred by Senator Sackett was the occasion he introduced an amendment to a bill dealing with the 1930 Census. Sackett sought to exclude aliens from the census count which would be used as a basis for Congressional reapportionment. His contention was that it was un-American and not in keeping with the ideas of the Founding Fathers to consider aliens in arriving at the numerical representation for a branch of government. Since most of the five million aliens in the United States at the time were located in the major urban areas, sackett contended their numbers would shift ten representatives to those areas, depriving the rural sections of representation in favor of the cities "with their alien hordes." Sackett was publicly chastized for his amendment by the New York Times especially for the implication that foreigners "are not as good as the native born.". The Times added that "Fortunately, the reapportionment bill in the Senate is in charge of Senator Vandenberg of Michigan who has denounced the Sackett amendment as unconstitutional." With the Constitution against Sackett, the Times added, "to base the proposed [census] reduction solely on racial origin is to 
carry xenophobia to an extreme." In the Senate debate on the issue, Sackett was vigorously opposed by both Republicans and Democrats and the amendment was overwhelmingly defeated. 11

When the Presidential Election of 1928 rolled around, Senator Sackett became most active in the campaign on behalf of Herbert Hoover. 'In his memoirs Hoover specifically cites Sackett as one of a group of men who informally took over the pre-convention effort to generate support for Hoover's nomination, an effort for which Hoover was obviously grateful. 12

In that same election year, Kentucky was considered a "pivotal state" in which neither Democrats nor Republican could claim a safe or clear edge. In 1924 Kentucky went for Coolidge and the Republican party and Sackett was himself able to ride into office on the crest of a "Republican national trend and a popular President who carried Kentucky by a sizeable margin." In previous elections, however, the State had gone heavily for Woodrow Wilson and, in 1920, for James M. Cox. The same year Sackett was elected to the Senate, a Democratic governor was installed in the Kentucky Statehouse and though the Republicans gained back the statehouse in 1927, Democrats had won most of the other state posts. ${ }^{13}$

Certainly a fact not lost on Sackett was that the Republican party had never carried the state in any election 
in which they had lost the Louisville vote. This prompted him to take a keen interest in insuring that his home town and state went for Hoover in 1928. Complicating matters was that the Republicans feared large interparty defections caused by a long time depression in the Kentucky coal industry (with the Republican party being held basically responsible for it) and by the Interstate Commerce Commission's decision to raise railroad freight rates, which worked against Kentucky mining interests, would virtually give the state's electoral votes to the Democratic party. Nevertheless, Hoover carried Kentucky in 1928.14

Although the stock market crash and the ensuing Great Depression were still unimagined events for the future, by the spring of 1928, the discontented state of affairs within Kentucky politics indicated an uncertain and difficult future for the Republicans. Sackett enjoyed his position in the Senate however and, in early October, 1929 announced his candidacy for renomination in the upcoming Republican primary. His confidence was bolstered by a reputation for being in on the inner councils of the party in the Senate, his recent appointment to the more influential Senate Finance Committee, that he was thought to be a close friend of President Hoover and, perhaps, by the fact that in 1924 he had. defied a long held political axiom in his home state that no one from Louisville could win a senate seat and that he was the only one to break the axiom in 90 years. ${ }^{15}$ 
Although his announcement that he would seek re-election generated speculation that his bid would be hotly contested, the Louisvilze Courier Journal, which had supported Sackett's Democratic party opponent in 1924 , stated that the incumbent "seems assured of renomination."16

\section{Summons From the White House: Sackett's Appointment}

Frederic Sackett's appointment as American ambassador to Germany was, in part, made to save the Kentucky Republican party from the embarrassment of an intraparty struggle and to avoid the possibility of Sackett's defeat in his general election bid in 1930. Republicans had noted the increasing strength and influence of a rising young state representative, John M. Robsion, who had proven to be a skilled organizer - smart politican and a native son of the Kentucky mountains. Sackett, on the other hand, "was a city man in a rural state, wealthy in a poor state, and had an Ivy League education and Eastern birth."17 Although Sackett himself may not have realized it, clearly the regular Republican machine was worried about Sackett's ability to win in 1930 .

Kentucky politics was not the only factor involved in Sackett's appointment however, as while Hoover was not totally innured to the political situation there, it only concerned one of several crucial "off-year" election contests in 1930. Conceivably, and perhaps coincidently, President Hoover recognized the long stressed need from 
within his own administration for an ambassador who would quickly grasp the main issues involved in the American relationship with Germany and be able to deal with them inside the realm of Hoover's own economic philosophies. Sackett's business background, his unquestioned support of Hoover, his prestige as.a United States Senator, and perhaps even his personal wealth could have been strong attractions for making this ambassadorial appointment. Hoover has indicated that a man of Sackett's outstanding "public service and personal distinction" would enable him to carry "additional weight" in representing American foreign policy to Berlin; that is, presumably more weight than that of a career diplomat. ${ }^{18}$ At any rate, the political difficulties seemingly faced by the Kentucky National Committee in re-running Sackett for the United States Senate, and its desire to dump Sackett from the state ticket, made his appointment as ambassador to Germany opportune for both the committee and for Hoover's own diplomatic needs.

Certainly there was no rush made to get Sackett out of the way after his early October, 1929 announcement to run for re-election; the President's summons to Sackett did not occur until December 25, 1929, almost three months later. In addition, Hoover had been under pressure for nearly a full year from his top advisors in the state Department to find a new ambassador for Berlin, though the post was not actually vacant. His advisors wanted a man who was business oriented, 
willing to tow the administration's line and keep a low profile. In light of his resume, Senator Sackett seemed a likely candidate to fill the order in any case.

After his appointment Sackett related that his nomination came as an "Xmas present in reality" even though the President had asked him to leave immediately after his confirmation by the Senate. Despite the haste of his departure, Sackett was correct when he said "I suppose a number of men have been in line for the appointment but it came unsolicited to me."19

In the latter part of 1929 , when it became generally known that Ambassador Jacob Gould Schurman would be leaving Germany, several suggestions were sent to the White House by prominent Republicans recommending possible successors for the President's consideration. One came from former Secretary of State Frank B. Kellogg suggesting Silas H. Strawn on the grounds he was an "able diplomat, has plenty of means, is a business lawyer of great ability, generally interested in national commerce and attends meetings international commerce [sic]." Kellogg said "I know of no other one who would fill that bill better than Silas H. Strawn of Chicago," and he was sure both Senators from Illinois would support him. Hoover's friend, Henry M. Robinson, a prominent California banker and a member of the Dawes Commission and hence considered knowledgeable about Germany's economic conditions, relayed second hand the suggestion of one 
Walbridge S. Taft of the firm Cadawalader, Wickersham and Taft of New York. Taft, a graduate of Yale and Harvard Law School, had recently resided in Berlin with an "outstanding position" and was "financially able to do the job and eminently qualified," as well. Robinson barely knew Taft and, without a strong endorsement passed it on to the White House "for what it is worth." Also referred (by an unknown) was Ira Nelson Morris, a former Commissioner General to Italy, Panama and Sweden, and an honorary Consul General at Chicago for Rumania. He had resigned from the foreign service in 1922 and was engaged in private financial businesses. 20

Retiring Ambassador Schurman made an interesting contrast to sackett, his successor, and while seemingly popular with his German hosts during his stay, was not so popular among many of the foreign service personnel.

Schurman, of German origin and a former president of Cornell University, was seen as too often taking the German point of view which, in the opinion of Assistant Secretary of State Williarn Castle, was "exceedingly unfortunate." In Castle's view, the American ambassador in Germany should be "willing and able to get along with the Germans, but determined to uphold vigorously American Rights, which the Germans seemed more or less willing to ignore." In a complaining letter to Hoover, Castle saw Schurman as being too proGerman for the good of America. 21 
An anti-Schurman feeling within the State Department grew out of complaints coming from Americans working in Germany. The most prominent came from the Agent General for Reparations, S. Parker Gilbert, who as early as May, 1927 complained that Ambassador Schurman had been talking tow much in public about the Dawes Plan "without instructions from home." Gilbert fixed an unofficial complaint through Treasury Secretary Andrew Mellon and continued his criticism of Schurman throughout the rest of the year. ${ }^{22}$

Finally, in January, 1928, Castle felt the need to. reprimand Schurman for alleged statements the latter made to the German press concerning a controversy between Gilbert and the German Government which the state Department considered "clearly a political issue in Germany," and therefore none of the Ambassador's business. After reminding Schurman of State Department-regulations concerning public statements on political issues made by diplomatic officers, Castle said Schurman's remarks "whatever may have been the precise words, have been of grave embarrassment to this Department." Schurman was reproached and his remarks repudiated by the State Department. ${ }^{23}$

But the problem did not end. Then Counselor of Embassy in Berlin, Dewitt Clinton Poole, noted in June, 1929 that the situation with Schurman was growing worse "... as the result I should say of rapidly advancing age," (Schurman was 74) and he expressed to Castle his hope for an early change. 
Poole (and, be adds, John Cooper Wiley, a secretary at the embassy) insisted that he had tried to cope with "the situation" for three years but, "I do not hesitate to say that our efforts have been in large measure successful." Poole characterized Schurman as "entirely out of touch with reparations and business questions and even got political questions tangled..." Though it seemed to suit the German interest that Schurman remain because of his friendly public attitude and because he did not "meddle too much" Poole said that as long as he were there to back Schurman up, the Germans could live with the Ambassador. The Germans, he said, felt that "the combination of Schurman and Poole produced as good a situation as one could hope to have and it would be [in the German view] the part of prudence to keep it undisturbed if possible." 24

A year after his reprimand of Schurman, Castle finally suggested to President-Elect Hoover that Schurman be dropped from the new administration's list of foreign service appointments. Though most changes recommended for the foreign service would not have to be made immediately, Castle considered a change at Berlin to be urgent. "Schurman invariably takes the German side in all negotiations and is a dangerous talker," he told Hoover. In his brief on Schurman sent to Hoover, Castle added that the ambassador "is a very careless speaker and is continuously getting the Government in hot water." A very different type of man was needed, 
Castle argued, especially during reparations talks with the European powers. ${ }^{25}$

In appointing a successor to Schurman, Castle wanted Hoover to consider someone with talents of a high order. "It is not a particularly pleasant position and, therefore, needs a man full of the spirit of service, a man trained in business rather than an intellectual like Doctor Schurman is needed." 26

Despite this appeal, Hoover delayed nearly a full year before replacing Schurman, who did not formally resign his position until January 21, 1930.

In announcing the Sackett appointment to Berlin on December 30, 1929 the New York Times noted that two of three top diplomatic posts in Europe had gone to members of the Senate (Walter Edge was posted to Paris). The third, London, went to millionaire former Vice President Charles G. Dawes who had been a member of the Senate the previous year. ${ }^{27}$ Meanwhile, the reaction in Berlin seemed favorable to the Sackett choice. Reporting the reaction of the German press, the Times said Berlin was presuming the appointment to be definite. Der Montag stated that Hoover "chose a personality with a thorough economic and financial experience since the special status of the United States demands at the Berlin post a self-reliant and resourceful man on economic questions." Though expressing surprise at Sackett's appointment specifically, Der Montag said it was generally 
known that Hoover intended to select a member of his wartime relief organization. ${ }^{28}$

Sackett's appointment met with a "cordial reception" in Berlin, the Times reported, with special accolades coming on the grounds that sackett "is reported to be a man of mature economic financial orientation." This qualification constituted, in German opinion, a valuable asset for Sackett because of the increased German-American post war relationship. ${ }^{29}$

The Berliner Tageblatt viewed Sackett's appointment as a compliment in that it placed Berlin on a par with London and Paris in American esteem, and "gives Berlin the future benefit of the service of a man whose influence with $\mathrm{Mr}$. Hoover and the American Senate, where issues of foreign policies are decided, will be amply vouchsafed," according to a Times report. Tageblatt stated that Sackett's appointment was a "New Year's gift to Germany" as he not only "wields weighty influence in his own political party, but also possesses sympathetic understanding for problems confronting Germany." In his brief on the German press reaction, Schurman informed the state Department that the Tageblatt had stated Sackett's appointment was for domestic as well as foreign political reasons. It was desirable "that Berlin have an Ambassador who can use his influence with Hoover and the Senate," where the important decisions were made. Stressed in other newspaper reports was that 
Sackett was an old friend of Hoover's which could be an asset, especially where German economic interests were at stake. Schurman further reported a statement in the December 31, 1930 Deutche Aligemeine Zeitung that "contrary to European practice, there is strictly no diplomatic career in America. America has, on the whole, fared well with diplomats who have not spent their entire life in the foreign service." 30

As for the most watchful journalistic eye over America's own diplomatic appointments, the New York Times was itself generally critical of the Berlin assignment by Hoover, viewing it as "frankly a departure from the older way of sending men of peculiar distinction" to represent the United states to the leading capitals of Europe. Sackett's appointment was seen as "something of a drop" from the caliber of previous ambassadors to naming a businessman. "But," the Times grudgingly stated, "the President is fully entitled to follow the new line of foreign representation, so long as he is convinced it is for the best interest of the nation." Hoover's choice confirmed "his preference for a businessman and a former Senator in an important diplomatic position." 31 The Times further speculated that Hoover was motivated by a desire to "bestow an honor" upon Kentucky which had given him a great majority in the Election of 1928.

But his main interest is doubtless to emphasize his idea of the immense importance of trade relations with Germany and other European nations. He is paying a compliment to Germany, as he did to 
France, by going outside the routine diplomatic service to choose an Ambassador who stands apart as the President's special selection to do a special work. ${ }^{32}$

As an "educated man of agreeable manners and distinct social gifts," Sackett would no doubt be accepted by Germany and, according to the Times, he would do what he could to "rebuild the bridge between the two countries, over which for so many years passed representatives of the culture and science of either to the great benefit of both." ${ }^{3}$ Although Sackett's appointment was seen as being in keeping with Hoover's "plan" of naming businessmen to certain important posts, it was also seen as solving "a troublesome political situation in Kentucky" where it was expected that the government there would appoint the likely Republican state primary candidate, State Representative John Robsion, to fill Sackett's soon to be vacated senate seat until an election in that state could be held. ${ }^{34}$

Back home in Kentucky, a menacing political situation had indeed been solved. The Louisville Herald Post, in announcing Sackett's appointment, proclaimed it "the highest honor of the kind that has ever come to a Louisville citizen," and editorially praised Sackett as one of those in whom the White House reposed high confidence. In going to Berlin Sackett would be important because "his intimate knowledge of finance is a positive asset." 35

But the impact upon Kentucky state politics was clear and more to the point. "This wholly unexpected termination 
of the senatorial career of the Louisville statesman ... came like a bolt from the blue in political circles in Washington," the Herald Post reported. And according to the Louisvizle Courier Journal, up until the moment of the announcement, it was felt Sackett's greatest concern wais to win renomination. ${ }^{36}$ The Washington correspondent for the Herald Post emphasized the administration's official explanation -- that Hoover wanted a man in "close contact with his economic policies" in the Berlin post. "The President is said to feel that Senator Sackett is thoroughly competent to represent not only the American viewpoint but the Hoover policies." 37

Nevertheless, the announcement was met with guarded enthusiasm, almost a sense of relief, by Kentucky Republicans. One newspaper stated Sackett would be leaving the "distasteful" game of politics "in which he felt he had to engage for the purpose of retaining his Washington position. He is to be congratulated on escaping from such a campaign for re-election as seemed to confront him." 38

It was political pressure from a faction supporting Robsion's bid for the Republican nomination for Sackett's Senate seat that "led Sackett to abandon his announced fight for renomination and take the diplomatic job," according to one correspondent. Still, the appointment took Washington by surprise. The capital city's "social, political, diplomatic and official circles are still buzzing today with 
gossip over the revelation that the president had plucked another Senator for the diplomatic corps as a means of meeting party vicissitudes." 39

Indications were that pressure on Hoover to make the appointment had come from Republican National Chairman Claudius Huston and Kentucky state Committeeman J. Matt Chilton of Louisville as a means for gracefully getting Sackett out of the way of the seemingly more attractive and youthful Robsion in the primary contest in hopes of preventing an adverse political situation in Kentucky from growing worse. ${ }^{40}$

The New York Times political analysts had anticipated a bitterly fought primary campaign between sackett and Robsion. With Sackett out of the way, Republicans could then unite behind Robsion. Still, the Kentucky Democrats were judged to be very strong and, if united, had an excellent chance of defeating native Kentuckian Robsion; a "chance that would not have been so good against Mr. Sackett." ${ }^{41}$

The state party machine was grateful to Hoover for his action. In a telegram to the White House, Chilton and other prominent members of the Kentucky State Republican organization thanked Hoover for Sackett's appointment, ironically adding that "...while political considerations had nothing to do with appointment the result thereof has brought harmony to the Republicans of Kentucky and the Republicans 
throughout the state are jubilant."42 Clearly, Kentucky Republicans were happy to see Sackett leaving.

Despite the benefits for the Kentucky Republicans, Sackett's appointment caused a minor political headache for Hoover. To send the Senator to Germany was, in effect, to exile one of his staunchest allies in Congress and specifically from the influential Senate Finance Committee, in the wake of the repercussions caused by the October, 1929 Stock Market Crash. Soon after the appointment was announced some Washington observers speculated that Sackett's confirmation by the Senate might be delayed in order to prevent renegade Senator Robert LaFollette from obtaining a position on the Senate Finance Committee. Some Republicans hoped Sackett's exit could at least be delayed until after the committee had acted on the Smoot-Hawley Tariff bill. ${ }^{43}$

Whatever the fears, Hoover conveyed Sackett's nomination to the Senate on January 9, 1930. Senator William E. Borah, chairman of the Senate Foreign Relations Committee moved the nomination be confirmed without referal to his committee and this was done by acclamation without discussion or objection. Sackett's letter of resignation was immediately read into the Congressional Record. On January 10, 1930 John Robsion was quickly appointed to fill Sackett's unexpired term in the Senate. ${ }^{44}$

Sackett's tribute in the Senate, offered on the occasion of his departure, is barely worth noting. The only one 
offered, and a short one at that, came from Republican Senator Royal S. Copeland of New Work who cited Sackett's work with the Committee on the District of Columbia as his most outstanding service in the senate. "I feel that the country is to be congratulated," Copeland said, "that we are sending a man so tactful and useful and forceful to the great German nation across the water..."45

Hoover's desire that Sackett leave as soon as possible for Germany left little or no adequate time for briefing by the State Department on the conditions in Germany, American foreign policies, and the ambassador's new duties. Initially, only a few days in London and Paris (and the latter stop was cancelled) were allowed Sackett for "consultation" with the American ambassadors in each capital. On January 22, 1930 Sackett and his wife sailed from New York bound for Europe, a scant 12 days after his confirmation as ambassador plenipotentiary by the United States Senate. ${ }^{46}$

On the same day as Sackett's departure, Out Zook magazine reported that politics had clearly played a major role in boosting the former Senator off the American shore. Sackett himself had become worried over the Kentucky political situation and did not "relish a fight or possible defeat" at the hands of Robsion. Hoover was worried about his paper thin margin in a Democratic party controlled Senate and, on the advice of the Republican National Committee got a thought-to-be-loser out of the way by sending him to 
Germany. "Thus," Outlook reported, "domestic rather than foreign politics accounts for the elevation of a second-rate Senator to a first-rate ambassadorship."47

In the case of Frederic M. Sackett's appointment to Berlin, Outlook asserted, even though little could be expected from him as ambassador, Hoover did indeed bring harmony to the party. ${ }^{48}$

Ambassador Sackett and His Reception in Germany:

Despite the fact that Frederic Sackett's appointment was greeted at least as being logical mainly because of his business background, key persons in the state Department were nevertheless wary of the ability of the apointee to get off to a good start, particularly since the Counseler of Embassy in Berlin, Dewitt Clinton Poole, had just resigned from the foreign service in order to start a teaching career at Princeton. 49 Even before Sackett's confirmation by the Senate Under Secretary of State William R. Castle it was suggested that Poole might return to Germany for a temporary period in order to help the new ambassador get started. However, after meeting with Sackett, top officials at the State Department seemed impressed enough with him so as to make the need for a special trip by Poole as "less likely," and in fact it was not made. 50

Poole was persuaded to meet with Sackett in Washington to spend but a few hours briefing the new ambassador on the Berlin assignment. As short as the meeting was, it was 
apparently enough to give Poole a very favorable impression of Sackett. Soon after, Poole transmitted his assessment of Sackett to his friend, the Acting Counselor of Embassy in Berlin, John Cooper Wiley. Poole described Sackett with his customary adjective -- that Sackett was "a peach" -- and emphasized Sackett would be a "delightful change" after their stormy relationship with Ambassador Schurman. "I am sure you find Sackett well disposed," Poole wrote. ${ }^{51}$

In almost no time at all, Wiley was echoing Poole's high rating of Sackett and even went to lengths to defend him from his critics. Though his relationship with Sackett was still quite new, Wiley chastized Time Magazine for a critical story about the new ambassador which he felt was unfair. In a personal letter to a Time editor, Wiley defended Sackett's quick departure from Washington as one made on short notice at President Hoover's request and not as a "slip away" as Time alleged. Wiley was cheered by Sackett's apparent discretion in refraining from uttering "banquet platitudes" since his arrival in Germany and he was pleased "to find an ambassador who does not wear his embassy as a cloak to his own vanity and who is not centered on selfadvertising," which to Wiley seemed an innovation. Wiley further characterized Sackett's Senate career as "influential and dignified" and praised him for having precisely the personality, capacity and knowledge, and cool point of view that are needed for the post. "He will have great success 
as Ambassador to Germany," Wiley remarked, and concluded his letter with "as a chief, he is a peach."52

Perhaps Wiley was merely trying to score points with his new chief, however, the relationship between sackett and Wiley remained on very good terms throughout Sackett's tenure in Berlin. Poole's influence did not only extend to Wiley but was imparted upon several contacts he made who would be going to Berlin. One example comes in a letter to Poole from a former colleague who was being transferred to Berlin from the Hague. "... I want to tell you that your new Ambassador is quite what you called him in your telegram to Wiley," wrote one W. deHaas.

The latter seems to be exceedingly happy about his new chief and so is everybody. To all appearances $\mathrm{Mr}$. and Mrs. Sackett conquer the heart of everybody they meet. Evidently due to you, Mr. Sackett has met me very cordially and our relations are very good indeed. I greatly appreciate the way he takes things on and tackles them straight away.

Sackett's niece, during a visit to Germany while he was ambassador, noted the excellent relationship between Sackett and his staff, especially the younger members towards whom he seemed "paternalistic." She said Sackett was "very thoughtful and kind with them and I think they genuinely loved him." 54

Upon Sackett's arrival in Germany to take up his assignment, Wiley reported to the state Department that the new ambassador received significant praise from the German press which highlighted Sackett's business background in their re- 
ports.

The press greeted with satisfaction the fact that $\mathrm{Mr}$. Sackett came from the Senate and attributed his appointment to the President's policy of sending abroad successful businessmen to look after America's economic interests. Most commentators inclined to the view that the new American ambassador would concern himself in no small degree with economic and financial questions, a field in which he enjoyed high repute in the United States. 55

Sackett received much favorable press comment by holding a news conference within 24 hours of his arrival in Germany, even before he had presented his credentials to President Paul von Hindenburg. The New York Times noted that Sackett, in handling the foreign press, "was equipped with something more than a correspondence course in diplomacy" when, in responding to a question as to whether or not he carried specific instructions from Hoover, he said "We had a most pleasant trip coming over."56

After Sackett presented his credentials to Hindenburg on February 12, 1930 and informed the President of Weimar Germany that his diplomatic instructions were the typical extensions of "fruitful cooperation," and "increasing friendly intercourse," and fostering "mutual understandings" topped by a "sincere conviction that German fortitude and industry" would solve the problems of the present and the future, the new ambassador settled into a relatively calm first year in Berlin. ${ }^{57}$ Sackett sought to maintain the Hoover Administration's philosophy of staying out of financial diplomacy of an unofficial nature, specifically in 
matters concerning private sector loans, He also wanted to keep the American Embassy out of any direct dealings concerning reparations or the creation of the Bank for International Settlements. ${ }^{58}$

However, Ambassador Sackett did play a cheerleader role in encouraging an increase in German-American financial relations, mainly as regards to trade; and initially advocated increases in American foreign investments overall. In a major speech before the American Chamber of Commerce in Berlin, Sackett pointed out that a new era in American affairs had started in recent years as its commercial life had clearly become interdependent with the prosperity of other countries. American business and finance, he argued, had begun to appreciate that due to the surplus production of goods in America, their own prosperity was literally interwoven with the internal economic conditions of every nation:

In an industrial country like America with its ample proportions and mounting surplus the expanding productive capacity seriously demands that that its foreign commerce be encouraged and safeguarded. There is no illusion prevalent at home that an export trade can permanently prosper unless through imports or by other method of transfer there shall be created an equivalent exchange of values with the world at large. In 1929 the export trade of America amounted to $\$ 5,150,000,000$. I cite these figures in no boastful sense but to give a clue to the economic reasons which influence America's foreign policies. ${ }^{59}$

Sackett added that the "importance of encouraging overseas exports is one of the foundations on which America has built her modern policy in the field of economic relationships." 60 
Right after Sackett's speech, the New York Times continued its barrage of criticisms over the appointment of politicians to diplomatic posts and on how United States Senators, after becoming ambassadors, turn up in Europe with an international view: "And now comes Ambassador Sackett in Berlin; another former Senator, a Republican and therefore presumably a high protectionist, making a speech about the 'interdependence of national prosperity and the prosperity of every other country." The Times chided Sackett for "piling one heresy upon another" by asserting Americans today were convinced their prosperity was interwoven with the world at the same time that high tariffs were being passed by Congress.

Such examples of rapid and useful education in the school of diplomacy suggest a change in our system. Why not have an alternation of Senators acting as ambassadors? Let each high tariff Senator be made an ambassador for two months and then [be] superceded and called back to vote on a Grundyized tariff with his eyes fully opened to what it means in our domestic production and our foreign commerce. ${ }^{61}$

The harsh criticism of the Times was unique in Sackett's diplomatic career for he rarely became involved in controversy during his time in Berlin, and few eyebrows were ever raised insofar as his performance as ambassador was concerned. One notable exception causing unintended publicity, however, was his address given at the World Power Conference in Berlin in June, 1930. Sackett forcefully hit American utilities for selling power at an alleged fifteen times the 
cost of producing it and stated that until the cost of power to the consumer was brought into line with the cost of manufacturing it then utilities were unjustified in claiming their quality service was offered at a low cost. Chicago utilities magnate, Samuel Insull, in Berlin for the conference, had tried beforehand to get the ambassador not to deliver his speech but when news of this leaked both foreign and American press seized on it as a denounceable "effort by a powerful businessman to ' $f$ ix' an ambassador of the United States." 62

The incident was all the more interesting because Sackett at that time was "believed to be a stockholder in the Louisville Gas and Electric Company."63 Although the controversy elicited mild responses, including a condemnation of Insull by Senator George Norris and denials of the Sackett charges by American utility executives, the whole event occurring as it did after the stock market crash worked to enhance Sackett's prestige as a businessman willing to protect the consumer interests in the face of a growing unpopular attitude toward large holding companies. ${ }^{4}$

A frequent criticism made of noncareer ambassadors is that they are prone to making more trips back to the United States during their tenure than a professional would ordinarily make. In nearly two and a half years while assigned to Berlin, Ambassador Sackett made only three voyages back to the United States: The first mainly for personal business 
reasons, the second to deal with problems concerning Sackett's coal fields in Kentucky and coincidently to brief officials in Washington of the difficult financial situation in Germany, and the third at his own expense to assist in Hoover's Presidential campaign of 1932.

When Sackett arrived in the United States on September 20, 1930 for his first trip home he told the press he intended to both vacation and attend to private affairs. ${ }^{65}$ While on leave in Kentucky, he wrote that "the short time at my disposal will all be taken in Kentucky looking after my business affairs, which need considerable attention"66; this trip is understandable given not only the state of the growing depression in the United States but also the fact that when he departed for Germany a scant eight months before, he had little time then to settle his financial affairs.

Sackett's niece later recalled how much the honor of his ambassadorship was costing Sackett: "While in Germany, and of necessity spending his own money fairly lavishly as an Ambassador," she wrote, "his securities at home were going down rapidly.:"67

Naturally Sackett took time to meet with State Department officials in Washington and brief them on the difficult economic situation in Germany. But an alarmist, on this trip, he was not. Conditions there were much the same as elsewhere in the world. Business was slow and unemployment was high, but he was confident that the obstacles to pros- 
perity that existed in Germany, as in America, would be overcome. He added that Europe was looking to the United States to start the recovery from the depression which, in Hoover's view, had paradoxically started in Europe. ${ }^{6}$ Yet no alarm was being sounded. The United states seemed to be slowiy recovering from the initial effects of what was still perceived by Hoover as a very brief economic recession "until April, 1931, when the earthquake of financial panic reached us from Central Europe." 69

After Sackett returned to Germany he continued to enjoy a relatively easy period in German-American relations and his esteem as Ambassador there seemed to grow. The local Louisville press, which closely followed Sackett's career in Germany, characterized him as "the right man in the right place" and as "the good silent ambassador" who did not waste time and attended to business. On January 24, 1931 after a year in Berlin, Sackett had "won the confidence of every American in Berlin, and formed a most satisfactory and effective contact with German authorities. ${ }^{70}$ Very soon, however, life for Ambassador Sackett became a great deal more complicated.

Sackett and Germany's Financial Crisis:

Sackett's celebrated second voyage to America, though indeed significant in further directing Hoover's attention toward the deepening economic and political problems endured by Germany, has perhaps been exaggerated insofar as its 
original motive is concerned. In his memoirs Hoover described it as an "urgent mission." Elsewhere it was termed an "emergency journey" to inform the President of the "disastrous financial crisis" which was, according to Reichschancellor Heinrich Brüning, then developing in Germany. ${ }^{71}$ As portrayed by Sackett at the time, Hoover envisioned Germany as a "great nation rapidly disintegrating" under the burden of unbearable debts and the cost of war. ${ }^{72}$

Urgent through the mission may have become, that was not Sackett's original intent for the trip. As early as February 26, 1931 he had requested to take his annual leave from the State Department for sometime during late spring and this was routinely processed and approved by the department. Between the time he requested leave and his April 24, 1931 sailing date from Germany, Sackett could not help but be preoccupied with news from the coal fields of Harlan County Kentucky of the United Mine Workers' strike which affected Sackett's own depression-plagued mining interests, especially those in Harlan and Bell Counties where his Black Star Coal and Pioneer Coal Companies were located. An explosion in the neighboring Black Mountain Coal Company mine on April 20, 1931 in addition to the on-going "Harlan County War" between miners and mine owners certainly did not ease his anxieties. On April 18, six days prior to his departure from Berlin, Sackett told the press that his trip home was his annual vacation leave and that while home he would at- 
tend the Associated International Chamber of Commerce meeting in Washington during May. At the time he sailed, both the Ambassador and the State Department in Washington denied attaching any political significance to his voyage. ${ }^{73}$

To further intensify Sackett's personal business concerns, almost as soon as he stepped off the boat he was greeted with news of the bloody May 5-6, 1931 "Battle of Evarts" between coal miners and National Guardsmen in Kentucky. Here the coal miners' strike reached fever pitch. And throughout May, events in Kentucky were alarming: Evidence of IWW participation was allegedly found; "Reds" were blamed by the Governor Kentucky for the strike; the National Guard was placed on alert; arrests in Harlan County (of the police chief and the assistant city clerk of Harlan, and of the local UMW president) were being made. Thus, at the time of Sackett's return trip to Germany, emotions in Kentucky were far from cool. ${ }^{74}$

However, while Sackett himself was preoccupied with his own threatened business situation during a time of deepening economic depression in the United States, this does not diminish the impact his reporting of the effects of the world depression in Germany. His goal was to convince President Hoover that major American action would be required to avert both economic and political disaster in Europe which, Sackett believed, would seriously affect the United States. 
Sackett's major attempt to alert Washington to Germany's increasingly difficult situation occurred after his December 19, 1930 meeting with Chancellor Brüning to review the volatile political situation facing the latter's conservative-to-moderate government. Brüning had impressed upon Sackett the threat of revolution within Germany if the social situation which was aggravated by the economics of war reparations was not eased in the long run. The Chancellor expressed the idea that the "building up of arms by almost all neighboring lands" near Germany would lead to increased agitation for the Reich to enlarge the size of her own military. This, he feared, would lead to further internal discontent. Brüning sought America's help and based much of his argument upon the role of Germany being the defender of democracy in Central and Eastern Europe. Sackett raised the question of Hoover hosting an international economic conference, which Brüning seized upon as America's chance to take a major lead in solving not only Germany's, but the world's financial woes. "I stressed the urgency of the whole proposition," Brüning wrote, "which would not only be suitable for the talents of the American people, but would also simultaneously deliver the peoples of Europe from. a certain dull despair."75

Duly impressed by Brüning's appeal for help, Sackett sent a detailed and confidential letter to Hoover portraying the dire straits in which Germany found herself and stress- 
ing that the Chancellor was the strongest character of Germany representing the responsible body of opinion within the Reich. Brüning was "not at all confident of the Government's ability to prevent serious disturbances" especially as the financial depression worsened, Sackett reported. The Chancellor feared such internal disturbances would come from Moscowdirected communists rather than from the followers of Hitler and that part of the economic depression was due to "unreasonable liberal credit terms offered Russia by the industrials" of major western powers seeking to capture the Russian market. But the real difficulty stressed by Brüning was the reparations question. ${ }^{76}$

Brüning told Sackett that if Germany were to be saved from chaos, a new study of war reparations was required, and the American Ambassador agreed. Though well aware of Hoover's feelings that war debts owed America by the European powers and reparations payments made by Germany to the European nations which opposed her in the war were separate issues, Sackett told the President that "my personal experience here leads me to think that we can very well maintain ourselves in any such discussion. Our position is in reality little understood, even by responsible ministers, and we in America have soon got to meet reparations again in the open anyway." Besides|, Germany was "bound to ask a new consideration of the Young'Plan payments," Sackett added. A world economic conference to study methods of overcoming the 
world wide depression and hopefully to deal with disarmament matters from an economic point of view might be useful, Brüning suggested according to Sackett, "because disaster here [Europe] would affect world trade everywhere." Sackett echoed the dire warnings of Brüning with the conclusion; that if internal explosions in Germany should erupt suddenly, "I am fearful it would definitely prolong the economic difficulties which we are facing in the United States and the repair of which you [Hoover] recently reminded our people was being delayed by conditions not within but without our borders." 77

Although favorable results were "eagerly awaited" after Sackett's effort, hopes in Germany were soon disappointed. In a polite but brief letter to the American Ambassador, Hoover mentioned he was grateful for receiving the information in Sackett's December 27 letter and thanked him for it. Without a concrete position from Hoover, Sackett was placed in an awkward position of having to confront Brüning's builtup hopes with lukewarm news. He explained that Hoover was greatly involved with the American depression and had taken no position on the matter of the economic conference. Sackett did not regard Hoover's response as a final indication of an American reluctance to become involved in European economic questions. ${ }^{78}$

Undaunted, Sackett and the American Embassy staff continued to send reports to Washington concerning Germany's 
growing financial and political plight. Deep in the throes of the depression in America, Hoover found little time nor apparently wanted to devote much attention to international affairs. However, during this same period, between January and May, 1931, Sackett became most alarmed at the growing threat to American interests which financial instability in Germany foretold. ${ }^{79}$

Further complicating problems, a proposed Austro-German Customs Union designed to unite the economies of the two major Central European powers was announced on March 21, 1931 setting off a "firestorm" of reaction by the French and British Governments which viewed it as a potential repudiation of the 1919 Versailles Peace Treaty -- "one of the keystones of which was the political separation of Germany and Austria," Hoover wrote. The President felt, however, that the proposal was "scarcely a serious menace" at the time and did little to encourage it. ${ }^{80}$ Renewed appeal to Hoover for an economic conference at this time also brought little response and there was little American support for reparations revision as the President continued to stress this as a separate issue from the question of war debts owed the United States by the World War I allies and feared the American people would not consent to get the United States involved in the political ramifications of European economic squabbles. By mid-April, 1931, faced with making more financial constrictions on the German people and growing politi- 
cal opposition -- particularly from the extreme Right and Left political wings -- the Brüning Government increased its pressure to get the United States to consider some form of increased economic support. ${ }^{81}$

Knowing Sackett was returning to the United States in late April, 1931 for a routine home leave, Brüning arranged to see the American Ambassador on the day before his departure to impress upon him that while Germany would do what it could to meet its obligations, it was not certain that the German people would accept additional sacrifices. ${ }^{82}$ At the eleventh hour Brüning attempted to use Sackett to get a dire message urgently across to Hoover about the growing German financial problem and its political threat to the Brüning Government. But this attempt, and indeed the crisis itself, occurred at a time when Sackett sensed American "unwillingness to help the Brüning Cabinet" and when the Ambassador's own interests were focused on the coal mines in Kentucky. ${ }^{8} 3$

Regardless of his business preoccupations, Ambassador Sackett appropriately went first to Washington to convey Brüning's assessment of Germany's economic plight. Prior to meeting with Hoover, Sackett dined with Secretary of State Henry Stimson and, no doubt, discussed major issues in Europe. Sackett presented Stimson with a glowing picture of Brüning as "the discovery of Europe" and indicated that he would not endeavor to raise difficult reparations questions until it was "absolutely imperative." But despite the 
significance of Brüning's warning of trouble for the future, Stimson seemed more impressed with Sackett's work in having "quietly engineered" a meeting between Brüning and the Prime Minister of England (set for June 5-6, 1931 at Chequers in England). Stimson, not noted for giving undue or exaggerated praise of subordinates especially within the ambassadorial ranks, registered in his diary that "Sackett himself is one of the best of our Ambassadors." He added, "I have been receiving the best of reports I have from any of the embassies through him and the meeting tonight rather confirmed my estimate of his good services." 84

As a lawyer and business executive with experience in public affairs, and being in a position to observe and keep his government informed, Sackett's credibility within the administration was considered high. Undoubtedly, Sackett's report to the President during his May 6, 1931 visit had a profound impact upon Hoover even though Sackett clearly stated that, in his opinion, the situation in Germany was not yet urgent. The Ambassador did advise that the situation was developing to potential crisis proportions and although there was no immediate danger, Germany could well collapse by the autumn of 1931 . Though skeptical of Brüning's use of the threat of communism, sackett used it in an attempt to alarm Hoover, and said that because of Germany's economic and political turmoil there was a real danger of internal revolution which, if it happened, would 
greatly affect the rest of Europe and, in turn, the United States. ${ }^{85}$

Further affecting Hoover was Sackett's analysis of the political problems in Germany. In his diary on the events surrounding the global economic problems he faced, Hoover recorded that Sackett painted the gloomiest picture of Germany and the Ambassador was convinced that unless the tide turned soon in the economic realm, the German situation would collapse. Especially aggravating the problem was the withdrawal of capital from Germany at alarming rates and the increased restrictions being placed upon credit. Unemployment was increasing and internal disturbances were becoming extreme. To a president already in an anxious state of mind over the American depression, such a report must have been unsettling. ${ }^{86}$

Sackett's report gravely impressed Hoover, however, as he continued to divorce debt problems from reparations payments, the President did not see what could be done. Perhaps a moratorium on intergovernmental debt payments was discussed at their meeting, but it was certainly not an original idea stemming from this session nor the first alternative considered as Hoover, at this point in time, preferred readjustments to the Young Plan installments as a more suitable means of softening the economic crisis. ${ }^{87}$

Sackett was unable to get from Hoover an immediate response to the problems in Europe beyond an expression of 
support for "liberal minded" men in Germany and elsewhere. Hoover did promise to undertake an in depth study of the situation and to discuss the matter more with Sackett when he returned from home leave the following June. ${ }^{8}$ The President began making inquiries and gathering reports (many of them independent of Sackett's previous reporting from Germany) and reviewed past reports from the American Embassy in Berlin -- almost all of which served to reinforce Sackett's gloomy viewpoint. ${ }^{89}$

Events began to steamroll as the crisis in Europe acutely developed during May, 1931 especially after the startling collapse of the largest bank in Austria, the Kreditanstalt, increased runs upon banks in Central Europe which presented growing threats to American securities there, followed by a severe drop in foreign orders for American wheat and cotton. During the last few days of May and the first days of June, German difficulties became so evident that "they were being openly discussed in the American press," Hoover noted. "The situation had developed far more quickly than Ambassador Sackett anticipated."90

Hoover, now admitting that the deepening affects of the depression had disrupted the whole fabric of intergovernmental debts "beyond the capacity to pay" under normal conditions, asked his Secretaries of State and Treasury -- Henry Stimson and Andrew Mellon -- to come up with a plan to relieve the pressure on the world economy. The failure of the 
Austrian Kreditanstalt on May 11, 1931 -- the "most important banking institution in the old Austrian Empire," in the President's recollection -- had confirmed for Hoover Sackett's view of the impending crisis. ${ }^{91}$

When Sackett revisited Hoover on June 2, 1931, the President's alarm was most apparent. He ordered the Ambassador to cut his "vacation" in Kentucky short and return at once to Germany so as to assure the Brüning Government that the United States would assist in the financial crisis especially with regard to easing the debts and reparations issues, and so that Sackett "might advise upon his arrival the reaction from the German Government." Prior to his departure, Sackett told Stimson he hoped Germany would not ask for a moratorium but felt that changes in the Young Plan to accomodate growing inflation would be preferable. Stimson noted that Hoover had moved to the position that reparations and debt revisions would be difficult to pursue as that would "open the door to all kinds of demands all over..." Sackett, Stimson wrote, was very concerned about the losses to American financial holdings and hoped American banks would adopt an accomodating stance toward Germany. ${ }^{92}$

Hoover's growing preference for a moratorium was no doubt bolstered by late reports from Germany which indicated. that, sooner or later and probably by the end of summer, the Reich would "precipitate" a discussion of reparations revision with "interested allied powers." Sackett's Counselor 
of Embassy in Berlin, George Gordon, informed Washington the Germans would force the issue of reparations revisions because of their internal economic situation. In essence, he said, "the buck is rapidly being passed" to the Americans if an economic crisis was to be prevented at all. Furthermore, Hoover learned that from the point of view of Wall street and particularly the House of J. P. Morgan and Company, the fear that Germany would not be able to pay her debts would have "almost as bad effects upon her immediate credit situation" in the United States "as the declaration of a moratorium." Morgan official Thomas Lamont expressed support for a delay in repayments. However, though Hoover was mindful of Wall Street's opinion he was not dictated to by the banking community. 93

In the course of his hasty departure from the United States, Sackett did not publically disclose any discussions he might have had with Hoover involving war debts and reparations problems and reiterated to the press a denial that he had discussed these issues with Brüning. ${ }^{4}$ Sackett left the United States on June 4, 1931 and before he arrived in Europe, Hoover was clearly leaning toward his momentous decision to extend a one-year moratorium on intergovernmental war debts rather than push for revisions. On June 5, 1931 Hoover expressed the fear that America was in the presence of a "great crisis" which would seriously affect American interests and was of the opinion that the 
..most constructive thing that can be done in the world economic situation today is that payments of intergovernmental obligations arising out of war ... be deferred for payment ....

to give the world one year for restoring domestic economies and recover from the depression. ${ }^{95}$

Fearful of adverse French reaction against conceswion to the Germans, Hoover tried to keep secret his decision for a war debt moratorium until technicalities could be worked out between the nations involved and Congressional support could be assured. However, leaks of the plan reached the press prompting Hoover's decision to make a premature announcement of the plan, on June 20, 1931, before France could be officially informed of it. Not until July 5 was agreement with the French reached and only then after terribly difficult negotiating sessions with a suspicious French government which attempted to demand political concessions in return for cooperation. "It was," in Robert Ferrell's words, "a big tangled mess." 96

In this interim period between Sackett's departure from the United States to the announcement of the moratorium, the American Ambassador to Germany played a key role in the delicate circumstances surrounding the affair. Having been instrumental in alarming Hoover to the crisis, it was now up to Sackett to keep his government as keenly aware as was possible concerning the attitudes and activities occurring within Germany, while at the same time pursue his own government's best interests. 
Rumors floated among international press circles that something was soon going to happen insofar as an American response to the European economic situation was concerned and Sackett did little to clarify the situation for reporters. Sackett's hasty June 4 departure from Washington, combiped with his seemingly coincidental meeting with Chancellor Brüning and Foreign Minister Julius Curius as they were returning from the Chequers Conference in England, helped heighten anxiety. Sackett's meeting with the two prominent Germans may have been more than chance as his departure from New York was remarkably well timed to coincide with the Chancellor's departure from England. The Ambassador's passage bookings were also made on the same vessel on which Brüning and Curtius were scheduled to return to Germany. For the purposes of press information, the Ambassador naturally considered it "courtesy to remain aboard" even though, he said, he had intended to disembark at Cherbourg. Sackett told the press the meeting gave him the opportunity to "exchange views" with the German officials who were fresh from. discussing economic relations with the British. ${ }^{7}$

Sackett did not publically comment on the content of the shipboard conversations with Brüning and Curtius, but it was believed by the watchful press that he briefed the Germans on how best to win American backing on reparations aid and encouraged them to continue attempts at improving their own economic position. Washington had indeed been alarmed 
at both press and American Embassy reports of a "German Manifesto" which indicated the Reich might declare a unilateral debt moratorium unless the war reparations could be renegotiated, and without indicating Hoover was inclined toward a moratorium himself, Sackett counseled the Germans not to force any action until international public opinion was prepared for it. ${ }^{98}$

Upon disembarking at Bremen in Germany, both Sackett and Brüning were noncomittal about their shipboard talks and the Ambassador informed the press that an international conference on debts and reparations would be unpopular with the American people. Hoping to facilitate a change in public opinion, at least in the American circles where it counted, Sackett and the embassy staff in Berlin continually sent back cables to Washington advising that "widespread outbreaks of public disorder were likely to develop at any moment and that there was doubt that the German Government could survive." 99 Between June 11, 1931 and the announcement of the Hoover Moratorium on June 20, 1931 Sackett frequently reported from Germany predicting dire consequences -- both politically and economically speaking -- unless the United States Government took official action to simmer down the pending domestic crisis, all the while making it seem the Germans "were at once considerate of American interests and also dangerously close to a unilateral moratorium." Sackett's reports had a cumulative affect upon Secretary of 
State Stimson who, by mid-June, 1931 saw the conditions in Central Europe as more serious "than we have had in any recent years," and had joined sackett in fearing for the political life of the Brüning Government. According to Stimson, the reports from the American Embassy in Berlin substantiated the premises on which the state Department had hitherto operated upon; namely, that while Germany was making a real effort to rectify its financial situation, their efforts were wiped out by the depression. Further, state Department economic adviser Herbert Feis had told Stimson that publicity should perhaps be given to the Brüning Government's financial difficulties as they really needed relief from reparations payments. 100

Stimson conveyed to Hoover the growing critical nature of the political situation in Germany as relayed to the State Department by Ambassador Sackett and his staff in Berlin -especially those reports expressing fears that the Brüing Government might have to quit the reins of power "unless a favorable element is introduced into the situation..." Sackett feared "a new government representing the disconcerted elements in Germany" would be installed unless some supportive action to Brüning was initiated by the United States. ${ }^{101}$ The President was indeed affected by Sackett's reports and by the urgency of the German situation (especially over outbreaks of widespread disorder) but expressed the need for a clear-cut statement of need for American help 
"signed by the highest German authority" which could help create a sense of justification for any action he might take. 102

Throughout the period before the moratorium was announced and during the subsequent two-week period of negotiations to secure French agreement to the payment postponements plan, Hoover and Stimson maintained close telephone contact with the embassies at Berlin, Paris, London and Vienna. All the while, Hoover held to the position that outright cancellation of war debts owed to Americans, as sought by the French, would be a guarantee for his own political death. The moratorium was to be a choice of the lesser of two evils, the other being the risk of default of large private American loans and of bank liquidations because of the German difficulty. ${ }^{103}$ Unquestionably, Sackett's reports of the ever depressing situation in Germany served to inform Washington that the financial and political structure of the Reich was more or less falling apart and had aided an indecisive Hoover in making up his mind. On June 21, 1931 Stimson placed a transatlantic call to Sackett requesting the Ambassador to obtain a letter from President von Hindenburg asking Hoover to help Germany. ${ }^{104}$

The attempt to get a letter was clearly made to stage an appeal for help although Hoover and some of his contemporaries imply it came unsolicited from Hindenburg. ${ }^{105}$ In fact, Stimson requested that Sackett secure the letter from 
Hindenburg describing the situation in Germany in order to reinforce Hoover's quest for Congressional support of the moratorium proposal. Stimson raised the point that such a letter might also sway American public opinion which, at the time, seemed to distrust bankers and felt the German crisis was a "a mere scare." According to stimson, the statement should insist the German situation presented grave problems for the entire world and stress the sacrifices already made by the German people. Already worried over increased runs on the Reichsbank and the drain on German gold reserves, Stimson asked Sackett to get Hindenburg's statement by June 21.106

Sackett immediately set to work. Understanding Hoover's need for a German plea, the American Ambassador contacted the German Foreign office which set about drafting a letter for Hindenburg's signature -- this done "under pressure" as the German President was in East Prussia at the time. Throughout the evening and late into the night of June 20, 1931 . Brüning and Curtius along with German Foreign Ministry State Secretary Bernhard von Bülow cooperated with Sackett to get a message to Hoover via diplomatic cable. But it arrived too late to be of service and, in fact, raised potential for embarrassment for the American President. ${ }^{107}$

As previously stated, leaks to the press and subsequent newspaper stories publishing "garbled" information about the moratorium plan prompted Hoover to give his story to the 
press. On the day of Hoover's announcement but after his official request to get a letter from Hindenburg, stimson urgently cabled Sackett that Hoover was making his statement to the press prematurely. Having received word that sackett had succeeded in procuring the Hindenburg letter, the sacretary asked sackett that it be kept confidential so as to avoid complications to the already delicate German financial situation and because it was feared the gloomy tone of the letter would limit the psychological boon of the moratorium announcement and further depress international morale. Confidentiality was, by this time, impossible as German newspapers were already aware of the contents of the Hindenburg message which had been leaked "by some high German official," according to Sackett, who claimed that every precaution had been taken to prevent it becoming public. ${ }^{108}$

Throughout the balance of his ambassadorship Sackett maintained an open relationship with the members of the press corps. However, during the delicate negotiations surrounding the Hoover Moratorium, he was sensitive to the potential damage to the bargaining positions of all the nations involved should details concerning the affair be leaked. Hence, the Ambassador scrupulously avoided any detailed conversations with reporters. After the Hindenburg letter was leaked, Sackett explained he was contacted by a New York Times correspondent in Berlin about the Hindenburg letter to Hoover and that is how he learned it was leaked. Sackett 
told the reporter

that as he knew, I was always glad to furnish such information on international affairs as was compatible with the public interest, but in view of the importance of President Hoover's action which was then in the press, I hoped that he would not ask me any questions of any kind on any subject, as my lips were sealed in the present instance. This he accepted,

Sackett rather pompously stated,

in the spirit in which it was given and willingly withdrew any question.

Sackett then explained to stimson that although he and the German Foreign Minister had implicitly agreed to withhold release of the Hindenburg statement as a matter of mutual courtesy, it was nevertheless leaked by a German source, "probably a cabinet officer."109

The response to Hoover's moratorium was immediate and hearty. At the time, the markets of the world felt the moratorium would halt the depression and, when the announcement was made, the New York Stock Exchange experienced significant upturns as the mood of bankers and businessmen improved. Ultimately however, this valiant effort proved to be too late. While from the outset it did forestall disasterous liquidations and was an act of political courage on Hoover's part, the premature announcement of the plan brought renewed French intransigence toward concession-making with Germany. Also, its desired affects were seriously diluted as it failed to halt the drain of gold reserves from Germany. After June 20, 1931 negotiations to secure French acceptance 
of the moratorium proposal geared up and the focus of American diplomacy shifted to Paris and Sackett's colleague, Ambassador Walter Edge. However, during the crucial two weeks which followed Hoover's announcement, the American Embassy in Berlin was far from inactive. ${ }^{110}$

During this period Hoover continued to maintain constant telephone contact with the major American embassies in Europe and no move was made without consulting him first. While the delicate negotiations proceeded, Ambassador Sackett was called upon to try and get Germany to voluntarily limit the increase of her naval armament build-up as a suitable response to the Hoover Moratorium and as a means to try and appease French psychology which was distrustful of any move which might allow the Reich more money to increase its military capabilities. At the same time, Sackett worked sympathetically with Brüning, "in order to avoid his overthrow by the radical opposition," -- especially from the right wing -by discouraging any concessions which might disturb German nationalism. As the financial crisis accelerated despite the moratorium, Sackett encouraged the convening of an international monetary and economic conference in London, scheduled for the summer of 1931, to discuss other means of helping Germany. ${ }^{111}$

Singularly impressed with the activity in Berlin, the New York. Times made page one notation of the frequency of appearance which Sackett's official limousine made in front 
of Chancellor Brüning's residence during the post June 20 two-week period: "Since' June 20, this car has been parked more frequently in front of the Brüning residence or the Curtius office than in front of the American Embassy, for Mr. Sackett is keeping in closest touch with the German Government." Although working nights and Sundays, Sackett was not keeping in much touch with the press as little substantive detail. of his visits with the German officials was printed in the newspapers. 12

In achieving the multipurpose goals of American diplomacy at this time, sackett was only partially successful. In the main, the French were disturbed over what they perceived as German insincerity while American negotiators were upset with apparent German aloofness and unwillingness to deal directly with France until the latter's unqualified acceptance of Hoover's moratorium was clinched. Although Sackett repeatedly informed the state Department that internal political conditions in Germany precluded Reich officials from getting involved in the French acceptance controversy, Stimson sought to placate the French by insuring that the Germans did not totally disregard France and attempt to deal only with the United States and Great Britain to solve their debt problems. ${ }^{113}$

Sackett attempted to reassure Stimson that Germany would settle technical problems of the war debt and reparations moratorium with France once the latter accepted the 
Hoover proposal in principle. Foreign Minister Curtius, the Ambassador stated, wished to emphasize amicable settlement with France on the finer points of the moratorium proposal and that both Curtius and Brüning "were well aware of the need for assisting French psychology," according to Sackett. "It was their intention to do what they could to make it easier for France to adopt the President's suggestion." Since the onus was on the Americans to insure this, the task became Sackett's main responsibility. ${ }^{14}$

Stimson definitely felt Brüning could do more, in Germany's own self interests, to make internal sacrifices. and he wanted Sackett to push towards getting them to support efforts to improve the financial situation in a more conciliatory fashion. "Brüning should be warned that it is for his own interest to help rather than be captious lest he produce a situation where France has successfully shifted to Germany the responsibility of non-acceptance of Mr. Hoover's proposals," Stimson admonished. Seizing upon an initiative by the British Foreign Ministry, to which Stimson agreed but with qualifications, Under Secretary of State William R. Castle asked Sackett if planned German battlecruiser expenditures were justified in light of the current circumstances and if Germany could be persuaded to drop the Customs Union plan -- a suggestion originally raised in American circles by Ambassador Sackett. ${ }^{115}$

Castle wanted Sackett to back up the British in their 
attempts to push for a German quid pro quo. He added, however, "I do not wish you to approach the Germans on these matters on your own initiative..." since to do so would give the appearance that American diplomats were involved in European political matters in defiance of American foreign policy tradition: They agreed the British should take the lead in attempts to get the Germans to forfeit the AustroGerman Customs Union proposal while Sackett would pursue the battlecruiser limitations as this was considered as a disarmament issue within the bounds of American interests. Sackett promised to "endeavor to elicit a less negative attitude" on the part of the German Government in hopes of facilitating the negotiations with France. However, he was less than optimistic as Brüning did not wish to take any steps which might be interpreted by his political opponents as "whittling away President Hoover's original plan," which was after all, asserted in the best interests of Germany. He stated Germany might be willing to go farther in making concessions despite its own wishes to get the best deal possible out of a total moratorium, but this would only happen if France and the United States reached agreement to delay war debts without including a statement on German reparations payments. 116

Meanwhile, Ambassador Edge in Paris suggested France would "use their key position" to impose certain conditions upon Germany, namely, naval disarmament, abandonment of the 
Austro-German Customs Union plan and the "cessation by Germany [of political activity] in the French spheres of influence in Central Europe and the Balkans." At least the first two demands had already been anticipated by sackett and Castle. Besides, as Castle informed Sackett on June 29, the American public (and certainly Congress) would be hardpressed to understand German construction of armaments while the United States sacrificed debt payments, ergo Castle urged the Ambassador to stress this point to Brüning. "He [Sackett] said that he was able to say anything to the Germans," according to Castle. 117

With orders to keep a low profile in concessions discussions, Sackett dodged the issue of the customs union in subsequent talks with Brüning but vigorously pursued the issue of reducing battleship construction as an aid to disarmament. His discussions were "balked" almost immediately as "naval construction is Hindenburg's pet hobby." Somewhat upset by Sackett's report, Castle retorted that the Ambassador should even more vigorously stress the need for German concession lest the negotiations with Paris founder. His anxiety was undoubtedly raised when Edge reported the French would abandon their still-on-paper planned construction of a 22,000 ton cruiser if the Germans would cease construction, already underway, of like naval vessels. ${ }^{118}$

Sackett, however, was aware of Germany's basic unconcern over the French attitude. If Franco-American conversa- 
tions over the moratorium had broken down over the question of German concessions the Brüning Government was well prepared to declare a unilateral moratorium before July 15, 1931, the day the next reparations payment came due. Distrustful of the security of the transatlantic telephone, Sackett preferred to cable this information back to Castle. Sackett further reiterated that direct German talks with the French over quid pro quo concessions could not commence until after the French accepted the Hoover Moratorium in its totality. For the United States to try to get the concessions, it would have been necessary to use the moratorium as a political lever and this neither Sackett nor Castle were prepared to do as such action was considered by American statesmen to be against the current of public opinion within the United States. Since the British were free to engage in political negotiations, however, Castle said he "would talk to the British Ambassador" in the United States. ${ }^{119}$

Growing increasingly exasperated, Castle asserted that some expression of appreciation from Germany of the cooperation and support of the nations involved in the Hoover Moratorium, France included, would be helpful in getting final French agreement. However, Sackett again blunted Castle's ire, reporting that in the German view, to publically applaud the French would be politically dangerous for the Brüning Government causing a precipitate rise in the tide of internal radicalism. Specifically, and contrary to the earlier 
reported fears that trouble would come from left-wing extremists, Sackett said he personally felt the danger came frow the "extremists in the Nationalist camp," implying, that is, from the followers of Hitler. Although the situation was "not so serious" as Brüning had felt it to be, the Ambassador defended Brüning's reliance upon (and appeasement of). the German military as necessary for the "saving" of Germany. This reliance was necessary to calm the Nationalists who were most vehemently against the 1919 Versailles Treaty the terms of which were viewed as harsh in its treatment of Germany. Likewise, to accede to the request to reduce armaments with its implication of renouncing the "meager rights" granted Germany in the Versailles Treaty would revive serious antagonisms both from the supporters of the German military and from the Nationalists. Sackett therefore acknowledged that Brüning could not take a firm stand toward the Nationalists since his moderate government was a small minority, vulnerable to the changing whims of President von Hindenburg, a vociferous and fragmented Reichstag, and increasingly strong political oppostition from the Right-wing in German politics. Clearly Sackett, as the "man-on-the-scene," sympathized with the interests and problems of the Brüing Government and was hesitant to pursue American interests beyond the point which he felt Brüning could not go. Sackett told Castle: "From the intimate association I have with the Chancellor I feel that the picture 
I have given above is his own honest view of the present situation in Germany."120

Despite Castle's (and Stimson's) discontent over the repeatedly negative attitude of the Brüning Government, the best commitment Sackett could extract from the Germans was a guarantee their armaments budget would not be increased as a result of the Hoover Moratorium savings. Otherwise, the Germans held that only a firm stand by the United States (and indeed, by Germany) would be effective in getting the French to agree to a total suspension of payments. At any rate Germany had nothing to lose by refraining from concessionmaking. 121 Although Sackett tried as best he could to get the Germans to soften their otherwise stiff posture, he could not overcome the often radical nationalistic influences which. primarily dictated the German domestic position against concessions.

Ultimately, on July 6, 1931 President Hoover's negotiating team in Paris secured French agreement to support the moratorium as it was originally proposed, with no substantial concession or exhibition of German gratitude. French agreement came reluctantly however, only after Hoover threatened to proceed with the moratorium without France. Though fraught with political risks for the American President, the moratorium negotiations stalled too long. ${ }^{22}$ On the same day Hoover announced French acceptance of the plan, Ambassador Sackett reported that a prominent American bank in Berlin 
would immediately begin withdrawing their short term funds from Germany. "If other large institutions in New York follow suit," Sackett cabled, "it will have the effect of a run on the Reichsbank and you can visualize the result."123

Bank runs and the drain upon Germany's gold reserves had been briefly stalled after Hoover's moratorium announcement in June. But as negotiations for French acceptance dragged out, the runs began again. Though it was hoped the finalization of the Hoover plan would stop these runs, instead they continued apace, adding a new slant to the German financial crisis: domestic panic which could well initiate a political revolution. Though exaggerating the situation, Brüning nevertheless impressed Sackett with the gravity of the situation who then notified the state Department that Germany was likely to again appeal for help. ${ }^{124}$

At least in Washington, the German appeal for a loan to see its economy through the latest difficulties fell upon concerned but deafened ears. In his reporting of the situation, Ambassador Sackett was resigned to the immediate position of the Brüning Government -- that it could not make further concessions which would antagonize the political opposition and hence France would "secure nothing from the present German Government" by continually pursuing a demand for a demonstration of "spectacular" gratitude. Therefore, France and indeed the rest of the Western world must be prepared to take its chances in supporting the Brüning Govern- 
ment or be prepared to cope with another government of the extreme Right.125 However, after the strenuous efforts to secure the Hoover Moratorium on Germany's behalf, neither the President nor the state Department was in a mood to exert any more efforts of an official nature.

Despite Sackett's efforts to get America to do more for Germany, Castle told him that even if the United States did something, it was probably too late to avert another financial crisis anyway. The ball was now in the German court, Castle related, and they would have to halt the gold drain on their own. This view was eventually reinforced by Secretary Stimson who stressed that more visible efforts at "self-help" in the German program would be necessary in order for Brüning to impress the United States. Even Hoover, who was truly alarmed at the devastating effects German bank failures would have upon American banks, merely notified American diplomats abroad that the whole matter was a problem for the bankers and that European banks would have to find their own solutions. ${ }^{126}$

Sackett agreed that Germany could give "far greater evidence of attempting to help herself," however he remained obstinate in defending the Brüning Government and its efforts to avoid being made to appear too conciliatory towards France and Great Britain. The Ambassador averred (erroneously it turned out) that Brüning would fall should a domestic moratorium on bank withdrawals be declared and, if 
that happened, he now feared an extreme Right-wing government would be instituted. ${ }^{27}$ But when it became clear the United States would take no new initiative to help halt the drain of German reserves, the government declared its own moratorium on internal banking activity commencing July 13 and in full force by July 14. The result, if not as drastic as the final end of the Brüning Government, was to push it further toward the breakdown of its political control within the Weimar Republic. ${ }^{128}$

On July 15, 1931 stimson recorded in his diary that "Sackett said that in his opinion Germany had done all she could in the way of internal restrictions," and that there was no chance of the Germans making a "generous gesture" prior to the upcoming economic conference set for later that month in London. However, faced with the full.impact of the economic crisis, the Brüning Government was forced to reconsider taking measures hitherto deemed undesirable. Sackett had attempted to influence the Germans to the American viewpoint of self-help and was of the opinion that Germany had long been "in the position of being willing to take everything and give nothing and of simply lying back and asking for help..." Sackett felt the present government was now prepared to make reasonable concessions in view of the real danger that it might fall from power if it did not take action. ${ }^{129}$

On July 19, 1931 the American Embassy reported Hinden- 
burg had issued a Presidential Decree to halt the flight of capital from Germany and two days later Sackett informed the State Department that the Germans were in a more conciliatory mood, ready to talk concessions with France in hopes of getting more economic help. This was an empty gesture since they were perhaps already willing to yield on the customs union plan which, for internal reasons, the Germans had decided would be unworkable anyway. But by this time, the Brüning Government was grasping for straws, as the mood was setting in that it was indeed too late to avert a loss of confidence in Germany. 130

Despite Sackett's appeals on behalf of Brüning, Hoover could not be persuaded to sanction any more private loans to Germany, nor would he commit the United States Government to help the Reich meet its short-term loan obligations. Disgruntled with Europe's failure to handle her own affairs, Hoover instead suggested a "standstill" of bank claims upon Germany until the financial situation could improve. The plan was accepted at the London Economic Conference on July 23, 1931, nevertheless the drain on foreign exchange continued at catastrophic rates. ${ }^{131}$

Throughout the period after the germination of the moratorium idea in President Hoover's mind and into the initiation of the standstill agreements, one of Sackett's major tasks as ambassador to Germany was to keep the United States Government as free as possible of political engage- 
ments. After America acted within the economic sphere, the onus was placed upon Germany and France to settle their political problems and emphasis on further financial difficulties were to be privately settled by the German Government and whatever private financial groups were involved. Althougn Brüning continued to express the necessity for extension of American initiatives -- including the widening of the standstill agreements and further reparations relief via the extension of the Hoover Moratorium -- Sackett recognized the limitations of American policy and the restrictions these limitations placed upon his freedom of action. ${ }^{132}$

Still impressed by the urgency of Germany's desperate financial condition and of Brüning's increasingly tenuous polticial posture, and especially of the threats emanating from both Left and Right wing radicals and from a discontented electorate, Sackett placed his hopes for Brüning's salvation in another economic conference of the major powers which "could only originate through the President of the United States..." Sackett conveyed back to Washington Brüning's continued appeals for a moratorium extension at least until the prevailing depression's ending could enable resumption of payments. But by late October, 1931, Sackett was no longer hopeful that the German financial crisis could be solved, despite further American initiatives. ${ }^{13}$

The situation had deteriorated as the result of a conspiracy by international financiers "selling the dollar 
short" in capricious speculation, Sackett told Hoover, in order to provide themselves "the necessary soft landing place" should Germany collapse. The Ambassador doubted any further concessions or compromises on the repayment of debts and reparations "would prevent a complete breakdown ecoljumically in Germany." At any rate, the internal political difficulties faced by Brüning during the depression were such that Sackett's efforts to garner foreign political support for him were fruitlessly doomed from the outset. ${ }^{134}$

In Secretary of State Stimson's view, all Germany, its people and leadership, were "gripped by fear -- of financial collapse, fear of revolution, fear of giving offense to the naive and innocent but very powerful Americans." This was causing a diplomatic impasse, despite the "sentiment of the ordinary American" and Stimson's own sentiments which held "that the Weimar Republic deserved the assistance and support of all who loved peace, if only to preserve it as a guardian against that other Germany which few -- and certainly not Stimson -- had forgotten." As the major powers began "entrenching themselves in self-righteous attitudes" and fell into "political impossibilities" the world lapsed into a rather hopeless situation which became more distressing as the world-wide depression grew. Throughout the crisis, Stimson felt Sackett had kept a cool head in Berlin and was correctly concerned with the whole psychology of economic panic. The Secretary further noted that sackett handled the 
foreign press in a tactful manner to get them to consider sympathetically Germany's problems and had tried to work towards improving confidence in the Reich. ${ }^{135}$

Sackett's Popularity in Germany:

Ambassador Sackett's efforts to aid the preservation of the Brüning Government were doomed to failure from the start as certainly the events which led to its downfall were outside the American ambassador's personal control. However, Sackett's efforts while serving at his post during this period were extensively observed by the American Consul General in Berlin at the time, George S. Messersmith, who rated the Ambassador's performance favorably. In a personal letter to Nation editor Oswald Garrison Villard, written in the midst of the July, 1931 financial crisis, Messersmith praised Sackett on his work: "The Ambassador has been splendid and has been doing an excellent piece of work. He has a very clear understanding of the situation, and he is helpful in many ways not only, of course, to our own Government, but by his counsel here."136

Because of his seven years spent observing first hand the political scene in Central Europe, and for having worked with three American ambassadors while in Germany, and since he enjoyed good relations with the state Department staff in Washington, Messersmith's opinion of Sackett is noteworthy. He was one who appreciated Sackett's business and banking background for, in his view, it enabled the Ambassador to be 
"quite understanding of the situation in Germany and realized that we should do what we could to help in order to avoid a government coming in which would be dangerous to stability." Messersmith stated Sackett was asked to go to Germany because "the President wanted a good sound businessman at the head of our embassy in Berlin at that time because the problems were, in large measure, economic." He saw Sackett as having good judgment, while being quiet, understanding and of firm conviction. "He did a very good job during his stay in the Embassy," Messersmith said. ${ }^{137}$

Beyond his official duties, Sackett was liked by Messersmith because he was willing and eager to make extensive visits throughout Germany, establishing contacts with heads of local government, businessmen, bankers and scholars outside of official circles in Berlin. But most of all, Sackett was praised for knowing how to use his staff and for trusting in them, something neither his predecessor nor his successor seemed completely able to do. ${ }^{138}$

For furthering Hoover's moratorium proposals, Sackett received strong praise in the German press. In a news story digesting the German press reports, the New York Times indicated a complete turn about in its own attitude toward the American Ambassador in Berlin. In distinction to prewar days, the Times pointed out that Germany since the war had been particularly fortunate in the diplomatic representatives sent from the United States. Sackett was an ambassador "who 
quickly got into intimate touch with men and things German and with keen judgment sharpened by wide business experience, rapidly grasped the essentials of the German problem. 139

Other honors also came to Sackett. On June 28, 1931 he was made an honorary member of the Institute of Foreign Politics and was cited as "the worthiest representative of a great people which, while confident of its own powers, has faith in the strength of others." On October 27, 1931, Sackett received an honorary doctorate from the Berlin College of Commerce. ${ }^{140}$ While such honors are not unusual for an ambassador to receive, some were perhaps arranged not only out of gratitude but to insure continued support and loyalty from the American Ambassador.

Sackett's major award was an honorary $\mathrm{PhD}$ in political science from the University of Tübingen -- Brüning's alma mater -- received in April, 1932. The suggestion for this "unusual honor" came directly from the Chancellor and Tübingen was picked as it had a well known School of Political Science and Economy "and because honorary degrees are so rare at Tübingen that the magnitude of the distinction is the greater." The New York Times stated Brüning saw Sackett as the man who suggested the Chancellor's trip to Chequers. Paris and Rome the previous June, 1931 which helped begin the steps towards Hoover's debt moratorium. In appreciation, Sackett was cited as recognizing the dangers which threatened the world economy "through Germany's economic crisis." 
Sackett had "energetically tried to ward off these dangers, proving himself Germany's warm hearted friend," according to the Times correspondent's report. ${ }^{141}$

Associated Press correspondent Louis Lochner reported favorably on Ambassador Sackett in a July 2, 1931 dispatch to the American press. According to Lochner, Sackett, "sooner than anyone had expected," became "one of Berlin's most popular ambassadors." His first press conference a year and a half before had won him the esteem of the Berlin press. In addition, Lochner termed Mrs. Sackett as "one of the most charming women in the diplomatic set." of sackett, the AP bureau chief stated "He likes conservative clothes and works hard."142

In Sackett's native New England, the Boston Herald praised the Ambassador for becoming a "genuine master of an intricate and difficult situation," especially in his handling of the debt moratorium. Although Sackett's appointment was at first considered as somewhat ridiculous, sackett "demonstrated conclusively that he was equipped to advise and confer as one who 'knew his stuff'," and in light of Sackett's performance the Herald cónceded that most Americans who had succeeded at business, politics or a profession "could likewise do excellent work as ambassadors."143

Certainly by late 1932 Sackett's popularity was at a high point as credit for his business-like approach to foreign affairs seemed to win him a great deal of contempor- 
ary acclaim. Sackett's niece would later reminisce that finance and economics were the Ambassador's natural element and, to him, the primary issues of concern involved those problems. "He always seemed to feel that the moratorium was his main triumph," she wrote.

The financial plight of Germany was his main worry and he felt it was central to the feelings and behavior of the German people at the time. In his view, they had suffered frightfully during the post World War I inflation, and lived in constant dread of recurrence. ${ }^{144}$

To be sure, this was an exaggeration of Sackett's motives. However, until Chancellor Brüning surprised Sackett with news of his resignation on May 30, 1932, the Ambassador had worked hard to do what he could to garner and strengthen American support for the Brüning regime which he viewed as the only hope of preventing Germany's slip into intractable domestic chaos. ${ }^{145}$

The Ambassador and the Election of 1932:

Ambassador Sackett's third trip back to the United States was undertaken for the clearly expressed purpose of helping the Republican Party in the presidential election campaign of 1932. One month before Brüning informed Sackett of his resignation -- an action which Sackett deeply regretted -- the Ambassador was preparing for a possible return, if necessary, to the United States to help the Hoover campaign. After learning the Kentucky state Republican delegation would support the renomination of Hoover at the 
summer national convention, Sackett asked the President if "a visit home prior to, or at the time of, the Chicago Convention would be required in the outcome [sic] and have held myself in readiness to go back to Kentucky should necessity arise." But at that point, with the Brüning Government still in shaky control of Germany, Sackett himself did not feel it necessary to leave Berlin for the convention "as I look upon the [Hoover] nomination as now assured" and because of "circumstances" which "have seemed to require my constant presence in Berlin this winter and spring." Personal problems of his second in command at the embassy, George Gordon, also demanded that Sackett remain at his post for the time. ${ }^{146}$ "Unless, therefore, you feel that I could be of real service to you by returning to the Convention," Sackett wrote to Hoover, "I shall remain here till september and return then for the campaign and election."147 Hoover agreed with Sackett in his decision to remain in Berlin, adding, "But I shall look forward to seeing you sometime during the Fall."148 When Sackett sailed for the United States on October 4, 1932 he told the press he was returning to consult with Hoover on the outlook of the world economic conference then being planned "and also hoping to take some part in the election campaign."149 Upon his arrival in New York Sackett told the press he had come home at his own expense as "the government had ordered all employees to take a thirty-day furlough," and therefore he was "free to do as I please." He flippant- 
ly added, "and one thing I please to do is to do what I can to help in the election."150

The ambassador then hit the campaign tour on behalf of Hoover both in New York and in Kentucky, as did many prominent Republican office holders in the administration who sensed the desperation of Hoover's chances at winning a second term while confronting the deepening economic depression and defending prohibition. Within the State Department, Secretary Stimson zestily undertook the defense of Hoover and of his foreign policy. Under Secretary of State William Castle was most active on the campaign trail emphasizing the debt moratorium as an example of Hoover's "decisive leadership." And Sackett called upon German-Americans to support Hoover "who has done so much for Germany."151

Sackett justified his political oratory by reiterating during his travels that he was on a 30 day unpaid vacation under the terms of the federal economy bill and was therefore "off the government payroll and entitled to come to this country and tell people what President Hoover has done for Germany." He frankly admitted his personal interest in Hoover's re-election and felt that criticism of his political activity, though he held a diplomatic post, was unjust. 152

Within the State Department, Assistant Secretary for Administration Wilbur J. Carr was concerned over the Sackett trip and emphasized that its political purposes be clearly separated from any official business. Although Sackett's 
original request was for a "short home leave" to allow for "consultation with the department on development of policies, et cetera," it was clear to Carr that the ambassador was returning to work in the Hoover campaign and would only be oncall for consultation if need be. Carr wrote to Castle

Obviously the Department should be extremely
careful not to attempt to put Mr. Sackett or
any other ambassador or minister under orders
for consultation for any period during which
his presence is not required here for the rea-
sons that the activities of these officers in
this country are being carefully scrutinized
and, in my judgment, neither the president nor
the Department can afford to have it appear, in
view of the intent of the Economy Act and the
acute political situation, that they are draw-
ing salary or expenses while in this country
engaged upon campaign work, as practically all
of them are. 53

Despite Sackett's hopes, it was a gloomy and depressing campaign for the Republicans. According to Stimson, "the immense undercurrent" was against the party and the people wanted a change. With the defeat of Hoover, Sackett became a lame duck ambassador and on November 12, 1932 he returned to Germany to wait out the transition of administrations. 154

And if the defeat of Hoover was not enough, Sackett soon saw the appointment of Adolf Hitler as Chancellor of Germany on January 30, 1933 and the coming to power of the extreme right wing in Germany -- no doubt a discouraging turn of events for the ambassador who tried so hard to help a more centrist government maintain power.

During the interregnum Sackett continued to take an 
active, if disheartened, role in European diplomatic affairs especially in the preparatory meetings for the world economic conference. 155

By March, 1933 Sackett was set to leave Germany as the new Roosevelt Democratic party administration took over the White House. ${ }^{156}$ As he prepared to depart, no effort was spared in showing the retiring ambassador appreciation for his service. The New York Times reported Sackett's farewell dinner given by the American Chamber of Commerce in Berlin at which Sackett was described as one of the most popular United States ambassadors sent to Berlin. "Rarely has an event in Berlin's American colony attracted a more representative gathering than that which taxed the Hotel Adlon's dining accommodations to greet Mr. and Mrs. Sackett," the Times stated. At a farewell Iuncheon on the eve of his departure, Sackett was not only greeted by the aged President von Hindenburg (a customary diplomatic function), but by the distasteful Chancellor Hitler and his top lieutenants as wel1. 157

On March 22, 1933 Sackett left Germany to stop off at Yichy enroute to the United States to undergo the "cure." Although his resignation submitted to Roosevelt was not effective until the appointment of his successor, the usually discreet Sackett permitted a final interview with the press. He offered no comment nor condemnation of the Hitler regime but did regret the "disappearance from Germany of liberty of 
the press and of democratic government." He blamed Germany's domestic troubles on its economic conditions and pleaded that Germany be allowed a major role in the planned world economic . conference. ${ }^{158}$

"During my stay in Germany," Sackett told reporter's, "I have found economics, as it almost has always been, at the basis of the nation's politics, and a great many of the political dangers of Europe can be, I am sure, overcome if there is a wise treatment of its economic problems."159

If Sackett was the right man at the right time when he came to Germany in 1930, the times had significantly changed when he left in 1933. Of course it was not known that events in Germany in early 1933 would, eventually, lead to a resurgence of the German military machine and, eventually, to World War II. But certainly well known -- if underestimated -- by that time was the pervasive world-wide Great Depression was causing a breakdown in the world order which had delicately existed in the 1920s. The conduct of foreign affairs on the part of all nations in a "business-like" economic atmosphere, instead of being treated wisely as Sackett would have hoped, was slowly giving away to a defensive, inward and cynical form of diplomacy leaving little room for friendship and trust and demanding greater political leadership than was ever required before. 
Perhaps, for Sackett's sake, it is just as well he left Germany when he did, while his own personal popularity. was high and before American and European relationships degenerated any further. 


\section{CHAPTER IV}

\section{CONCLUSIONS -- RATING AMBASSADOR SACKETT}

With the selected criteria from Chapter I pages 38-40 in mind, how does Frederic Mosley Sackett's performance as ambassador to Germany stand up in relation to critical judgment in view of the fact of his nonprofessional status and relative inexperience in diplomatic affairs? The following brief summations give guidance in making an overall assessment :

\section{Motives for the Appointment}

Obviously and inescapably, there were strong political motivations for Sackett's ambassadorial appointment on the part of the Kentucky State Republican leadership and hence on President Herbert Hoover who was himself placed in a difficult political situation with the onset of the Great Depression. After Sackett had declared himself a candidate for renomination for the United States Senate, and then was confronted with potentially strong and attractive opposition which threatened to split Kentucky Republicans. In the face of a seemingly strong Democratic opposition, Sackett's appointment was viewed not only as a political pay-off to the state of Kentucky for its support of Hoover in 1928, but 
also a chance to get an incumbent out of the way for a more attractive candidate.

But conclusions over the motives for the appointment itself cannot end here, for if political expediency was the only Hoover objective, this could have easily been accomplished by sending sackett to a less important post than Berlin. Given the conditions of the time, it was in the best interests of the Hoover administration to place a man with Sackett's background and qualifications in an important post like Berlin where the problems dealt with concerned business, finance and economics. For almost a year before the Sackett appointment was made, Hoover was under pressure by the State Department to send a man like sackett to Berlin. It can even be considered as within Hoover's own philosophical framework (given his pronouncements during his Latin American visits) that a successful businessman like Sackett could be regarded as a "professional" in the sense that he was an expert in finance problems. In addition, Hoover could not have based Sackett's appointment simply upon the whims of the Kentucky political organization, for he himself worked with Sackett in administering the United States Food Administration during World War I and had contact with Sackett while he was a Senator serving on the Interstate Commerce, Commerce and later Finance Committees while Hoover was Secretary of Commerce. In addition, Sackett was known to be loyal to Hoover personally. 
Although Castle in the state Department considered appointing a new ambassador to Berlin as most urgent when Hoover took office in March, 1929, it was the last of the great European diplomatic posts to be filled. Whether or not the President ever seriously considered appointing a career foreign service officer to the post, which could have been done if the need were that serious, is not clear. However, when the political difficulties in Kentucky more or less pushed Sackett into the "availability ranks," Hoover's need to fill the Berlin post "with just the right man" was conveniently satisfied.

2. Congressional Responsibility

As Senate tradition calls for the expeditious approval of a nominee to a position when he is a member or a past member of the Senate, no investigations were made into the Sackett ambassadorial appointment; no questions or reservations concerning the suitability of the appointment or the competency of the nominee were raised.

Sackett's appointment did initially and modestly upset the operations of Congress mainly because of his removal from the important Finance Committee which provided an opening for the advancement of the maverick Senator Robert LaFollett's -- never and administration favorite -- ascendancy to it. However, this did not ultimately delay Sackett's confirmation. One can assume that Sackett's position as Ambassador to Germany, taken in combination with his 
former position in the Senate, was not a negative factor in the administration's relations with Congress especially when sensitive international problems arose ( $i . e .$, the debt moratorium) which required consultation with the Senate.

3. Relations with the President

Sackett's personal relationship with Hoover remained good throughout their long association and must also be considered when looking at his nomination to the Berlin post. Hoover favorably cited Sackett in his memoirs both on the occasion of the President's preconvention campaign in 1928 and in appointing Sackett to Germany. The President described him as one of the "outstanding citizens". who "carried additional weight." Sackett had relatively easy access to Hoover whenever the need to see him arose, and communciated (though less successfully) with the President via personal letter. However, his relationship with Hoover was not used to circumvent normal state Department channels and he enjoyed good relations with its Washington officials as well.

Sackett was a loyal Hoover supporter, thoroughly versed in the President's political views and policies and he represented them well to highest government officials in Berlin. Sackett's direct influence upon the administration is harder to gauge, though it has probably been generally underestimated. Hoover has cited Sackett for more or less making him aware of the adverse political situation in Germany during the spring and summer of 1931, and he has also 
been given credit for sustaining administration support for the Brüing Government after the initiation of the debt moratorium. It is safe to say Sackett was attentively listened to by the administration even if the latter did not always react in accordance to the ambassador's preferences.

\section{Personal Wealth}

Although Sackett was certainly a wealthy man which provided him with time (before October, 1929) to participate in public and political service his wealth did not hinder his effectiveness as ambassador. Berlin was considered a post which, at the time, was beyond the normal means of a career foreign service officer to maintain on his own salary. Sackett did a great deal of entertaining and lived in fairly expensive residences which, according to members of his own family, required expenditures beyond the salary and expenses paid for by the State Department. While it may have been one important consideration, Sackett's appointment was not based upon his wealth nor amount of political monetary contributions. However, it must certainly have been a consideration in his personal decision to accept the appointment in the first place.

5. Cultural Ability

Although Sackett had traveled abroad prior to being nominated as ambassador, he possessed no special expert knowledge of conditions in Germany nor of its economic back- 
ground prior to his appointment in 1930. He knew some of the German language, but his speaking ability was minimal and required that he undertake private lessons while in Berlin. His official business therefore, was naturally conducted either in English or through an interpreter. However, in a relatively short time, Sackett was "quick to grasp things German" and became well versed on issues there. Also, his embassy staff no doubt provided a great deal of assistance to him in terms of German protocol, customs, traditions. etc.

\section{Private Career}

Sackett's background as a businessman and his experience as a politician greatly enhanced his on-the-job abilities while in Germany, according to the foreign service people with whom he worked. Consul General George Messersmith was particularly pleased that sackett was able to relate quickly and well with economic matters involved in Germany at the time. John Cooper Wiley incisively noted the difference between Sackett's professional approach to economic problems as compared to Schurman's. Sackett's business background was especially appropriate because, at the time, though State Department policy dictated an unofficial involvement, most of the real relationships between Germany and the United States involved private sector financial investment. 
7. Character Suitability

According to most observers at the time, Sackett was at least outwardly suited for the role of ambassador. His appearance was good. The New York Times, members of the Senate, personal friends and supporters in his home state, members of the foreign service, and Hoover himself found Sackett to be charming, conversant, public-service minded, intelligent (quick to grasp complicated situations, George Messersmith had said), polite and relatively cool in difficult situations. Sackett was outgoing -- willing to meet people and spend time with them -- and was enthusiastically greeted and liked by his German hosts, as well as the American community in Germany which, like Sackett, was predominately of a business orientation. In sum, he did not make many enemies while ambassador and certainly alienated no one political group, although he may not have become too close to them either.

\section{Image Representation}

Although Sackett was far from being a member of America's prestigious or wealthy upper classes, neither was he an average middle class citizen. He did perhaps represent what seemed to be regarded as the American ideal man of the 1920s: a business man, successful, well-educated, an active member of his community, a good family man and a loyal supporter of his government and political party. Sackett reflected a certain Republican aspiration and ethic which many in America 
thought to be the dream of fulfillment in their "land of opportunity." In this sense he did perhaps act as a museum piece for the United States, although this was not the purpose of his appointment to Germany.

9. Relations with Embassy Staff

Throughout his tenure in Berlin Sackett enjoyed very good relations with his staff at the embassy, perhaps because he supported their work and relied upon them, was "paternalistic" towards them rather than interfering and dictatorial. Sackett worked especially well with Wiley and his chief Counsel of Embassy George Gordon, as well as Consul General George Messersmith. Few, if any, complaints are to be found against sackett from his staff as are in evidence against Sackett's predecessor. On several occasions, members of the American Embassy staff in Berlin cited Sackett for providing insight and guidance to their work. Although not particularly inspirational, Sackett did seem supportive of the work done by the staff and was the type of person who generated a respectful loyalty from subordinates by adapting to their methods rather than by introducing or forcing upsetting changes to their routines. Unlike Jacob G. Schurman before him and William E. Dodd after him, Sackett did not criticize the way of life led by the career men at Berlin but instead adapted himself to it, perhaps because he enjoyed the diplomatic style of social life as well as his staff did. 
10. Diplomatic Skill

As exhibited in his delicate negotiations concerning the debt moratorium, during the German July financial crisis, and his interaction with the Brüning Government in general, Sackett appears to have been an efficient, competent emissary to a foreign government. At least it can be said that Sackett made no serious blunders which might have alienated and isolated other diplomats. He conducted himself with the proper distance from various and potentially difficult unofficial parties (allowing his staff to handle any direct associations of this kind) and maintained excellent relationships with the government in power without seriously jeopardizing his objectivity and duty towards maintaining America's best interests. His inexperience in diplomacy appears to have been no handicap and although he was decidedly proBrüning Government, there is little to really support the suggestion of Foreign Minister Julius Curtius that Sackett was "in the vest pocket" of the Germans.

\section{Respect and Popularity}

To what extent Sackett was respected by the German Government is not easy to determine. Certainly no attempt to isolate him was made, nor were any gratuitous deferences paid to him. Ambassador Sackett did at least enjoy a certain respect paid to the representative of any great nation however. His popularity in Germany was considerable. 
Certainly Sackett's executive skills learned during his business career, and the fact that he was an administrator both in private life and in public service, enhanced his ability to operate an embassy. In addition, Sackett enjoyed the excellent services of two experienced career Counselors of Embassy who normally took care of the routine details of the embassy allowing sackett time for making the more important personal contacts within the German Government. In addition, Sackett maintained close communication with the State Department. This removed the need for making decisions on the spot -- a natural trend in American diplomacy since the introduction of the transoceanic telephone -- but placed more onus upon the mission in the field for carrying out the decisions of the administration to a more exacting extent than had otherwise been the case in diplomacy in the past. In other words, independent of the Ambassador, most of the focus for decision-making was passed to Washington, although Sackett was still important in interpreting and transmitting the information on which decisions were based and in the carrying out of day-to-day negotiations with the host government.

13. Political Sensibilities

It is clear sackett was thoroughly aware of the political situation inside Germany during his tenure there as ambassador. He personally maintained close contact with 
German Chancellor Brüing until the latter resigned in May, 1932 after which cordial relations with successor governments were maintained until Sackett left Germany. Unquestionably Sackett was pro-host government and especially was pro-Brüning and did not attempt to hide his feelings. However, he interpreted the crisis faced by the government relatively clearly for Hoover, falling back on devices only when deemed necessary to get his own government's attention. Unlike other ambassadors, Sackett was not so stubbornly opinionated as to color his judgment and to prompt one-sided reports of minimal use to the state Department.

\section{Reporting}

Generally speaking, major officials in the United States Government were pleased with the quality of the reporting coming from the American Embassy in Berlin. Although at one point there was criticism from inside the Department for a lack of interpretive reporting, a complaint coinciding with the absence of John C. Wiley from Berlin, Stimson himself paid Sackett a rare compliment for the quality of the reports from Germany. In addition, Sackett's three visits to Washington during his tenure no doubt helped to clarify in person any information stated in many of the important reports sent to the state Department.

\section{Host Country Reaction}

Sackett was well received by the official and unoffi- 
cial circles in Germany and well liked throughout his stay. Only a matter of days passed between the time Hoover sent the nomination of Sackett as Ambassador to the German Government for its approval and their very favorable response with virtually no questions asked. According to American officers in Germany and the New York Times, the German press was complimentary in their response when Sackett began his tenure and were most praiseworthy of his performance when he left. Of course, due to Sackett's work on behalf of the Brüning Government, this served to enhance his esteem in the Weimar Republic despite the eventual downfall of that government. Sackett was not ignored by the German government although at times German officials seemed patronizing towards him. Although Sackett was careful in his unofficial contacts, he did travel about the country making them.

\section{Personal Prestige}

Sackett's positions as United States Senator, successful businessman, and personal friend of Hoover all helped to increase his stature as ambassador, as these traits were all considered desirable and beneficial to the self interests of Germany. Especially noteworthy was the thought that Sackett would have a great deal of influence not only with Hoover but in the Senate as well. Despite America's official isolation from political and economic affairs in Europe, the United States was still regarded as the most important country in the world and the one which could objectively 
deal with European problems. In this light, the German government was happy to receive the recognition from the Hoover Administration of the importance of Berlin in post World War I European affairs that the Sackett appointment appeared to imply.

America's foreign policy towards Europe in the 1930s was ineffective and especially short-sighted, at least in terms of its response to the problems in Germany. Despite its economic power, the United States by its own choice did not have the requisite political leadership capabilities to significantly influence or alter events there. Political isolationism retained a strong hold over the thoughts and actions of the Hoover Administration and although Americans, and especially the financial community, shared a great interest in European affairs, it had placed definable limits on its policies beyond which it would not move; or if it did, it moved timidly and reluctantly. ${ }^{1}$

In examining the situation surrounding America's response to the difficulties in the Weimar Republic and of Europe in the early 1930s, it is evident the United States attempted to save a political system by assisting it with economic means. The belated recognition that the vicious cycle of war reparations and debt payments, plus the alleged misuse of capital development loans, were effectively bleed- 
ing the economic strength of Europe, and the declaration of the Hoover Moratorium to try and halt that drain was consistent with economic philosophies of most of the men shaping American foreign policy at the time. While the United States sought the cooperation of the several European nations involved, the moratorium was, at heart, a unilateral defensive action to forestall further bank failures in the United States and seemingly did not involve intractable ties to European political difficulties. ${ }^{2}$ To take action beyond this, in the economic realm, would have necessitated increased American loans -- officially sanctioned and perhaps guaranteed by the United States Government -- yet it was felt this meant sending good money after bad and naturally the Hoover Administration could not condone this. ${ }^{3}$

Outside economics, the only recourse for action was in direct political intervention in the inter-relationships of Europe. American isolationism during the 1920s was not absolute as the United States did engage in limited political activity in matters deemed important to its own self interests. The interwar period of the 1920s and 1930s indeed marked a watershed in increased American involvement in foreign affairs, probably because of its superior and farflung economic situation. However, aside from President Hoover's own restrictive philosophies governing American political involvements abroad and his distaste for foreign intrigues in general, it is unlikely that most European 
nations (except Germany perhaps) would have welcomed an "unsophisticated" Uncle Shylock to presume a right to get involved after it had clearly rejected a leadership role in refusing their 1919 invitation to join the League of Nations. ${ }^{4}$ More than this, however, American statesmen by 1930 were again fearful of domestic public opinion and a profound isolationism which was more intense, dynamic and less tolerable of dissent -- an isolationism born mostly out of economic depression which had grown even less likely to permit extensive political commitments in Europe. To have flaunted the axiom of perceived public sentiment against political entanglements, they believed, would be committing political suicide especially during a time of severe economic depression at home. ${ }^{5}$

Given this sitatuion, it is difficult to see what other alternatives or responses open to the United States would, or could, have altered events a great deal. ${ }^{6}$ Certainly they were beyond the control of any one man, and the American Ambassador to Germany at that time should not be strictly judged alongside policies which failed deșpite his attempts to make them work. Untrained in the tradiational conduct of diplomacy, Frederic Mosley Sackett brought to Berlin a background in practical business and economics which was suited to the affairs then prevalent between Germany and the United States. The motives for his appointment were a mixture of political necessity coinciding with the practical diplomatic 
needs of the Hoover Administration. At the same time, he enjoyed a prominence which did command more attention from the administration, more so than might otherwise have been the case had even a career foreign service officer been in charge of the American Embassy in Germany.

While it is interesting to speculate on the differences in the level of influence and action had a career man been ambassador in Berlin, it is doubtful the outcome of events would have been significantly changed. Judged in the context of the times and world relationships in the early 1930s, his own merits and on the considerations of his contemporaries, Frederic Sackett was a successful ambassador to Germany for the United States. 


\section{NOTES}

Chapter I: The Historical Controversy

${ }^{1}$ Frederick van Dyne, Our Foreign Serice -- The ABC of American Diplomacy (Rochester, N. Y., 1909), 62-63.

${ }^{2}$ Charles W. Thayer, Diplomat (New York, 1959), 255.

${ }^{3}$ Ibid, 255.

${ }^{4}$ Ibid, 256-257.

${ }^{5}$ Ibid, $242-244$.

${ }^{5}$ Ibid, 251.

${ }^{7}$ Ibid, 253-254.

${ }^{8} I b i d, 258-259$.

${ }^{9}$ Ibid, 259-260.

${ }^{10}$ Ibid, 262-263.

${ }^{11}$ Ellis Briggs, Farewell to Foggy Bottom -- The Recollections of a Career Diplomat (New York, 1964), 36-37.

${ }^{12}$ Ibid, 38.

${ }^{-13} \operatorname{Ibid}, 40-41$.

${ }^{14}$ Ibid, 42 .

${ }^{15}$ Ibid, 44-45.

${ }^{16}$ Ibid, $45-46$.

${ }^{17}$ Ibid, 46-47.

${ }^{18} \mathrm{High}$ Gibson. The Road to Foreign Policy, (Garden City, N. Y., 1944), 50 .

${ }^{19}$ George F. Kennan, "The Future of Our Professional Diplomacy," Foreign Affairs, Vol. 33, No. 4 (July, 1955), 573. Kennan did set some criteria for an American Ambassador going 
to Russia which is worth noting. In an excerpt from. "The United States and Russia" written in the winter of 1946 the former charge d'affairs and yet-to-become ambassador himself, Kennan wrote that the mission must at all times be led by someone capable of and prepared for hard and tedious work over a long period of time, someone who has in high degree the qualities of modesty and patience, who is animated solely by devotion to the interests of our country, and is generally fitted by personality and background to earn the respect of a nation unexcelled in the psychological analysis of the human individual. In the case of Ambassador Harriman, for example, "I can sincerely say that I consider these prerequisites filled." But for the future, Kennan argued, the State Department should be prepared to use its influence to see that it is effectively filled. "A vain, fussy, and ignorant ambassador is capable of breaking its back, and of doing lasting (if not readily apparent) damage to the fabric of Russian-American relations." Refer to Kennan's Memoirs, 1925-1950 (Boston, 1967) 564-565.

${ }^{20}$ Congressional Record, 85 Cong., 1 Sess., 14833-14839 (Aug 15, 1957); New York Times, Aug 7, 1957, 12:6.

${ }^{21}$ Ibia, Aug 6, 1957, 13:1.

${ }^{22}$ Congressional Record, $i b i d$. Senator Mike Mansfield, later to become ambassador to Japan in the Carter Administration, agreed in general with Humphrey but pointed out that there were "some of the noncareer ambassadors who, in my opinion, perform able, distinguished, and outstanding service representing this country." Most were contributors to their "respective parties" but they did perform well, he said. "There is room for contributors in a democratic system such as ours. It is fortunate that many of these people have turned out to be so adept and so capable in the posts to which they were assigned."

${ }^{2}{ }^{3}$ Claire Booth Luce, "The Ambassadorial Issue: Professionals or Amateurs?" Foreign Affairs, Vol. 36, No. 1 (Oct, 1957), 105-106.

${ }^{24}$ Ibid, 107.

${ }^{2}{ }^{5}$ bid, $115-116$.

${ }^{26}$ Ibid, 118 .

${ }^{27}$ Ibid, 119.

${ }^{28}$ Ibid, 120.

${ }^{29}$ Graham H. Stuart, American Diplomatic and Consular 
Practice (New York, 1952), 135.

${ }^{30}$ Richard C. Snyder and Edgar S. Furniss, Jr., American Foreign Policy (New York, 1954), 333.

$$
\begin{aligned}
& { }^{31} \text { Ibid, } 311 . \\
& { }^{32} \text { Ibid, } 332-333 . \\
& { }^{3} \text { Ibid, } 333 . \\
& { }^{34} \text { Ibid. } \\
& { }^{35} \text { Ibid. }
\end{aligned}
$$

${ }^{36}$ Brookings Institute, United States Foreign Policy -Formulation and Administration (Washington, 1960), 111.

$$
\begin{aligned}
& { }^{37} \text { Ibid, 111-112. } \\
& { }^{3} \text { Ibid, } 112 . \\
& { }^{39} \text { Ibid. }
\end{aligned}
$$

${ }^{40}$ Kenneth W. Thompson, American Diplomacy and Emergent Patterns (New York, 1962), 89.

${ }^{41}$ Ibid, 90. Thompson further asserts that "If history is past politics and diplomacy, historians should stand in the front rank of American diplomats. Indeed, by any standard, the list of our professional historians who have carried responsibility abroad is impressive." He cites George Bancroft, John Lathrop Motley, Andrew D. White, William E. Dodd as examples. "Their numbers increase if diplomats turned amateur historians are added." Not all amateur historians rank with the foremost American diplomats, but a few, such as Charles Francis Adams and John Hay, earned universal and well-deserved acclaim. Of Adams, it is said that no less than the generalship of Grant and Sherman his diplomacy preserved the Union by forestalling any move by the British Navy to throw its full weight to the Confederate side." Thompson adds that "if historians as a group have showed any weakness, it has been in accepting and operating within the limitations of their role as representative and spokesmen for an American administration." And for some historian/ambassadors, "discretion and self-restraint have proven too painful a burden to bear." William E. Dodd is cited as an example; "Because of his prophetic appraisal and righteous hatred of Hitler, destroyed his lines of contact and thereby his usefulness in Berlin."

$$
{ }^{42} \text { Ibid, } 94 .
$$


${ }^{43}$ Ibid, 86.

${ }^{44}$ Ibid, 95.

${ }^{45}$ Ibid, 96.

${ }^{46}$ Ibid, 99.

${ }^{4} 7$ James L. McCamy, The Conduct of the New Diplomays (New York, 1964), 239-241. McCamy also states that aftir the 1924 Rogers Act, both Secretaries of State Charles Evans Hughes and Frank B. Kellogg were most supportive of career men despite President Coolidge's indifference.

${ }^{48}$ Ibid, 202-204.

${ }^{49}$ Ibid, 241-244. Military men examples McCamy specifically cites are Admiral Alan G. Kirk, former ambassador to Belgium, Taiwan, and later the Soviet Union; Walter Bedell Smith, ambassador to the Soviet Union.

50 Ibid, 245.

${ }^{51}$ Ibid.

${ }^{52}$ Ibid, 246.

${ }^{5}$ Ibid.

${ }^{5}$ Elmer Plischke, The Conduct of American Diplomacy (New York, 1950), 200.

55 Ibid, 198.

${ }^{56}$ Ibid.

${ }^{57}$ Ibid, 199.

${ }^{58} \mathrm{E}$. Wilder Spaulding, Ambassadors Ordinary and Extraordinary (Washington, 1961), 293-296.

${ }^{59}$ Ibid, 295.

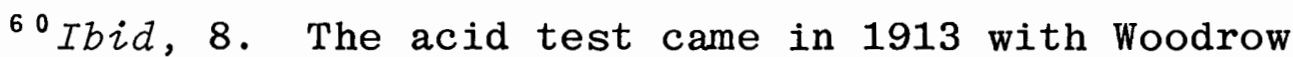
Wilson. "If any President could have been expected to justify the system of a free presidential hand in the appointment of chiefs of mission, the former president of Princeton, reform governor of New Jersey, student of American politics, and victor over Taft's old-Iine Republicanism should have been the man. Yet virtually every expert from Graham stuart to Walter Mills has criticized the Wilson appointees," Further, "It was beside the point that Wilson did not know in 1913 
that the world war was less than a year and a half away. No future President when he rewards his campaign contributors, the party machine which supported him, or even the ladies who entertained him royally in ashington society, will know when a world crisis is in the offing. The fact remains that Woodrow Wilson named a group of chiefs of mission who were to be innocents abroad in a world where there was no innocence." Of the first 51 Wilson-Bryan appointees to chigf of mission assignments, only two had previous experience. "Ibid, 9 .

$$
\begin{aligned}
& { }^{61} \text { Ibid, } 11 . \\
& { }^{62} \text { Ibid. } \\
& { }^{63} \text { Ibid, } 13 . \\
& { }^{64} \text { Ibid, } 58-59 . \\
& { }^{65} \text { Ibid, } 94 . \\
& { }^{6} \text { Ibid, } 130 .
\end{aligned}
$$

${ }^{6}$ Ibid, 155. This often generalized view of William E. Dodd is refuted in Robert Dalleck, "Beyond Tradition: The Diplomatic Careers of W. E. Dodd and George S. Messersmith, 1933-1938" South Atlantic Quarterly, Vol. 60, No. 2 (Spring, 1967) 233-244; and in Democrat and Diplomat: The Life of William E. Dodd (New York, 1968). Ambassador Dood, Sackett's successor in Berlin, was Franklin Roosevelt's sixth choice for the post after five other prominent Democrats turned down the offer. Still, he was no more or less qualified to be ambassador to Germany, Dalleck argues. A noted academician specializing in the history of the South, Dodd had no expertise in German politics at the time of his appointment and could barely remember some of the German language he learned while a student at Leipzeg 36 years before. What was key to Roosevelt's thinking however, was that his designs for the selection of an ambassador to Germany included the desire to send a man with democratic leanings who would serve as an American expression of hostility to the objectionable events going on under the Hitler regime. (This contrasts with Hoover's desire to place a representative with business expertise to come to grips with Germany's more predominate economic problems.) In Roosevelt's search for an ambassador a career man was not really considered for the job as they were viewed as unfriendly to his liberal domestic and foreign policies and because he basically did not trust them. Dodd shared this distrust of the career men and disliked their lifestyle and described his own staff in Germany as inefficient and "frivolous in the extreme; $i b i d, 187-191,214$. Insofar as his on-the-job performance, Dalleck's assessment of 
Dodd is corroborated by the American Consul General in Germany during the 1930s, George Messersmith: "I often think that there were very few men who realized what was happening in Germany more thoroughly than he did," Messersmith wrote of Dodd, "and certainly there were very few men who realized the implications for the rest of Europe and for us and for the whole world of what was happening in the country [Germany during the 1930s] than he did." Messersmith felt that Roosevelt could have appointed a better known, more spectacuipr man than Dodd, however he did feel the appointment was made with deliberation. "The President knew the importance of having the right man there," but Dodd's assignment "was not too well received in many quarters."; Papers of George $S$. Messersmith, University of Delaware, Dover, Notes for Memoirs.

${ }^{6} 8$ Spaulding, Ambassadors Ordinary, 179 . Women ambassadors discussed by the author were Ruth Bryan Owen, Florence Jaffray Harriman, Perle Mesta, Helen Eugenie Moore Anderson, Claire Booth Luce and Francis E. Willis. Miss Willis was the one "pro" up from within State Department ranks, but was deprived of previous diplomatic postings before becoming a Minister.

${ }^{69}$ Ibid, 206, 216-217. Cited as examples were William O'Dwyer (who, though an unscrupulous politician, was a "supremely good ambassador,"), Joseph P. Kennedy; playboy Jimmy "Golden Boy" Cromwell; meat packing heir John Cudahy; Alanson B. Houghten of Corning Glass Works; steel magnate Myron Taylor; Macy's Oscar Strauss; and cloth merchandiser Maxwell H. Gluck who, despite the uproar over his appointment to Ceylon in 1957, had "done us no great harm" insofar as relations with Ceylon were concerned. Ibid, 236.

${ }^{70}$ Thomas A. Bailey, The Art of Diplomacy -- The American Experience (New York, 1968), 35 .

$$
\begin{aligned}
& { }^{71} \text { Ibid, } 45 . \\
& { }^{72} \text { Ibid, } 46 . \\
& { }^{73} \text { Ibid, } 51 . \\
& { }^{74} \text { Spaulding, Ambassadors Ordinary, ix. }
\end{aligned}
$$


Chapter II: The Hoover Commitment

${ }^{1}$ New York Times, March 5, 1929, 1:3-6; Herbert Hoover, The Memoirs of Herbert Hoover, the Cabinent and the Presidency 1920-1933 (New York, 1952), II, 222; Public Papers of the Presidents of the United States: Herbert Hoover; Containing the Public Messages, Speeches and the statements of the President, March 4 to December 31, 1929 (Washington, 1974), 8-9.

${ }^{2}$ Ibid; New York Times, March 5, 1929, 30:1. In reflecting on Hoover's inaugural address, the New York Times was critical of Hoover for professing high ideals for world peace and of the United States for not taking its proper place in the World Court, all the while turning its back on the most outstanding tool for peace, the League of Nations.

${ }^{3}$ Fred L. Isreal (ed.), The State of the Union Messages of the Presidents, 1790-1966 in three volumes; (New York, 1966), vol. III, 2748.

${ }^{4}$ Ibid. In Hoover's second annual message to Congress, on December 2, 1930, just after the October, 1929 stock market crash, foreign relations was the last subject dealt with. By the time of the third annual message, on December 8,1931 , the "world-wide" economic crisis was the predominate theme of Hoover's passage on foreign affairs and the urgency in Germany was of "highest importance" rather than the need to restore normal relations in Latin America; Ibid, 2782, 2784; See also Robert Ferrell, American Diplomacy in the Great Depression, Hoover-Stimson Foreign Policy, 1929-1933 (New York, 1957), 3

${ }^{5}$ Hoover, Memoirs, II, 335.

${ }^{6}$ Warren F. Ilchman, Professional Diplomacy in the United States, 1779-1939- A Study in Administrative History (Chicago, 1961), 132.
${ }^{7}$ Ibid, 139.
${ }^{8}$ Ibid, 157 .
${ }^{9}$ Ibid, $157-158$.
10 Ibid, 159.
11 Ibid, 167.
${ }^{2}$ Ibid, 183-187. Essentially the Rogers Act combined the diplomatic and consular services into a combined foreign service; professionalized officers below the rank of minister 
and ambassador; provided appointment via open and competitive examination with promotion strictly on a merit basis; established a salary and retirement scale; and gave a system for representation (entertainment) allowances. See W. Wendell Blancké, The Foreign Service of the United States (New York, 1969), 18-19.

\section{${ }^{13}$ Ilchman, professional Diplomacy, 210-211.}

14 Ibid, 211-212. Especially laudatory of Hughes and Kellogg for their efforts in promoting the interests of career men, and for an in depth look at the makings and "frame of mind" of the professional foreign service in America during the 1920 s see Robert D. Schulzinger, The Making of the Diplomatic Mind: The Training, Outlook and Style of United States Foreign Service Officer, 1906-1928 (Unpublished dissertation, Yale University, 1971) and Dexter Perkins, "The Department of State and American Public Opinion" in Gordon Craig and Felix Gilbert (eds.) The Diplomats, 1919-1939 (Princeton, 1953), 283, 286.

\section{${ }^{15} \mathrm{New}$ York Times, Oct. 6, 1928, $5: 2$. \\ ${ }^{16}$ Ibid, Oct. 7, 1928, 3:5; Feb. 12, 1928, 32:6. \\ ${ }^{17}$ Ibid, Oct. 10, 1928, 6:2. In diagreement with} Coolidge was prominent New York banker, former journalist and former special attache for political-economic affairs (in the Division of Western Europe Affairs) for the Department of State, and a prominent Republican, William Augustine Scully. In a letter to the editor of the New York Times, he argued that the career men's status should not change with administrations. Scully, who assisted in drafting the 1924 Rogers Act asked: "What worthiness or application has the Rogers law, providing as it does, the maintenance of a corps of American foreign service officers under the jurisdiction and administration of the Department of state if, after having been given ministerial or ambassadorial rank based on long service and efficiency, a change in the political party directing the nation's welfare, reduces his to a lower grade, with the alternative of resigning? We might just as logically demote the personnel of our armed forces after they have obtained what is commonly known as permanent rank." Ibid, Oct. 21, 1928, III 5:5. The precedent of career men not submitting their resignations along with the partisan political appointments at the time of administration changes was broken by Hoover's Secretary of State Kellogg at the beginning of the new term at a press conference when, "taken of $f$ his guard," Kellogg stated that career men would follow the custom of submitting their resignations, which a number of service men did do. "President Hoover not only refused to accept the resignations of 
those career men, but increased the number of chiefs of mission drawn from the career service," according to Graham H. Stuart, The Department of State: A History of its Organization, Procedure, and Personnel (New York, 1949), 262.

${ }^{18}$ New York Times, March 15, 1929, 7:1.

${ }^{19}$ Ilchman, Professional Diplomacy, 212. Ilchman notes that this status for career personnel was not too greatly reduced during Franklin D. Roosevelt's Presidency despite his well known distrust of the foreign service.

${ }^{20}$ Herbert Hoover, The Memoirs of Herbert Hoover, Years of Adventure, 1874-1920 (New York, 1961) I, 476.

${ }^{21}$ Joseph Brandes, Herbert Hoover and Economic Diplomacy -- Department of Commerce Policy 1921-1928 (Pittsburg, 1962), 10 .

${ }^{2}$ Ibid, 155. "At a time when the prevailing Republican emphasis was on curtailment of government expenditure," Brandes writes, "Hoover succeeded in increasing Congressional allocations for the foreign activiites of his Departments." Ibid, 13. See also William Starr Myers and Walter H. Newton, The Hoover Administration - - A Documented Narrative (New York, 1936), 540 .

\section{$2{ }^{3}$ Brandes, Economic Diplomacy, 27.}

24 Ibid, 41. Hoover's "foreign service" in the Commerce Department clashed with the state Department mainly over the supervision of capital exports from the United States, according to Brandes, and by the attempts by Commerce officers and attaches to "take over some of the functions of the consular officials" since assisting American businessmen abroad became the primary function of its people working abroad. Over a period of time, it seems that Hoover's people and their publications concerning business conditions in a given country became in some instances more reliable than were the State Department reports. By 1927, the Department of Commerce "already was acting as the Administration's official spokesman on economic foreign policy." Brandes points out that the problems of cooperation between the State and Commerce Departments were to remain serious due their competition up to the time of Hoover's nomination for the Presidency in 1928. Ibid 41, 45, 48-53, 57, 59; see also Hoover, Memoirs, II, 79, 85, 117.

${ }^{25}$ Hoover, Memoirs, II, 177-179; Brandes, Economic Diplomacy, 170-174. 
${ }^{26}$ Ibid, 183-186. See also Joan Hoff Wilson, "A Reevaluation of Herbert Hoover's Foreign Policy," in Martin L. Fausold and George T. Mazuzan (eds.) The Hoover Presidency (Albany, 1974), 164-186.

${ }^{27}$ Myers and Newton, The Hoover Administration, 41; Brandes, Economic Diplomacy, 197.

${ }^{28}$ Hoover, Memoirs, II, 210-211; Brandes, Economic Diplomacy, 199 .

${ }^{29}$ Ibid, 201-203.

${ }^{30}$ Hoover, Memoirs, II, 333-335; Brandes, Economic Diplomacy, 210 .

${ }^{31}$ Hoover, Memoirs, II, 210-211.

${ }^{32}$ Ibid, 215.

${ }^{3}{ }^{3}$ bbid, 334; Ray L. Wilbur, The Hoover Policies (New York, 1937).
${ }^{34} \mathrm{New}$ York Times, March 16, 1929, $18: 2$.
${ }^{35}$ Ibid, April 4, 1929, 1:7; April 5, 1929, $24: 1$.
${ }^{36}$ Ibid, May 19, 1929, III, $1: 8$.

${ }^{37}$ Ibid. In an editorial the Times suggested that when Hoover talked of placing "professionals" in Latin American posts, perhaps he really meant competent businessmen; Ibid, Nov. $9,1929,18: 3$.

532.

${ }^{38}$ Myers and Newton, The Hoover Administration, 531-

${ }^{39}$ New York Times, Nov. 17, 1929, III, 1:8. The Times correspondent pointed out that Hoover was sending professionals to missions regarded as "on the firing line" and, in 1929, these important missions were regarded by Hoover as being in Latin America where the major American foreign policy mission was completely to change past relationships there.

${ }^{40}$ Wilbur, The Hoover Policies, 585-586. Without ceremonial fanfare or commentary, Hoover signed an Executive Order on June 11, 1931 which placed more emphasis on the merit system for professional advancement and also provided for raises in salary scales and post allowances. New York Times, June 11, 1931, 20:1. 
${ }^{41}$ Perkins, "The Department of State and American Public Opinion," 286.

${ }^{42}$ Henry L. Stimson and McGeorge Bundy, On Active Service in Peace and War (New York, 1947), 191.

${ }^{43}$ Ferrell, American Diplomacy in the Great Depression, 35-37; Hoover, Memoirs, II, 219, 336-337.

${ }^{44}$ Stimson and McBundy, On Active Service, 156; Ferrel1, American Diplomacy, 37.

${ }^{45}$ Ibid, 38-39; see also Robert Ferrell, "Henry L. Stimson," in Robert H. Ferrell (ed.) The American Secretaries of State and Their Diplomacy (New York, 1963) XI, 158 .

${ }^{46}$ Stimson and McBundy, On Active Service, 194.

${ }^{47}$ Ibid, 177.

${ }^{48}$ Ibid, $193-194$.

${ }^{49}$ Ferrell, "Henry L. Stimson," 164.

${ }^{50}$ Ibid, 207-208.

${ }^{51}$ Stimson and McBundy, On Active Service, 214-217.

${ }^{5}$ Perkins, "The Department of State and American Public Opinion," 284-285. $39-44$.

${ }^{5}$ Ferrell, American Diplomacy in the Great Depression,

${ }^{54}$ Ibid, 4-5.

${ }^{5}{ }^{5}$ Herbert Hoover, The Memoirs of Herbert Hoover, The Great Depression 1929-1941 (New York, 1952), II I, 1-5; Hoover had hoped the readjustment of the economic system, despite the "orgy" of stockmarket speculation preceeding the Great Crash of October, 1929, would be orderly. Loath to make the effects of the crash worse, Hoover attempted to explain the problem as part of the "normal business cycle" readjusting disequilibriums, but he claims he was not impressed by optimistic reports of a quick recovery which were issued at the time. Nevertheless, he hoped the crash would prompt corrective measures in the weak American banking system; ibid, III, 19-21, 30 .

${ }^{56}$ Ferrell, American Diplomacy in the Great Depression, 13; Hoover, Memoirs, III, 107. 
${ }^{7}$ Ferrell, American Diplomacy in the Great Depression, 15; see also Arnold A. Offner, The Origins of the Second World War: American Foreign Policy and World Politics 1917-1941 (New York, 1975), 45, 52, 64 .

${ }^{58}$ Melvyn P. Leffler, "Political Isolationism, Economic Expansion, or Diplomatic Realism: American Policy Toward Western Europe 1921-1933" in Donald Fleming and Bernard Bailyn (eds.) Perspective in American History (Cambridge, 1974), VIII, 416-419; see also Henry L. Stimson, "Bases of American Foreign Policy During the Past Four Years" Foreign Affairs (April, 1933) vol. 11, No. 3, 385.

${ }^{59}$ Leffler, "Political Isolationism," 419.

${ }^{6}{ }^{0}$ Ibid, 421, 423-425; Ferrell, American Diplomacy in the Great Depression, 110.

61 "The End of Isolation," Journal of the American Bankers Association, 24 (August, 1931), 78-74, as cited in Leffler, "Political Isolationism," 431.

${ }^{6}{ }^{2} I b i d, 439$.

${ }^{6}$ Offner, The Origins of the Second World War, 50; Leffler, "Political Isolationism," 444-445.

64 Ibid, 65-66.

${ }^{65}$ Bernard V. Burke, "American Economic Diplomacy and the Weimar Republic" Mid-America, Vol. 54, No. 4 (October, $1974), 212$.

${ }^{6}$ Leffler, "Political Isolationism," 442-443; Leffler states that the great failure of American policy was that nothing was done for over a year after the London Conference. "Hoover and Stimson, though very much interested in disarmament on the land and the seas, made little effort to convince the public or the Congress of the need to revise the nation's neutrality practices. The Administration's negligence on this matter can only be explained in terms of the more pressing domestic economic issues and international financial questions posed by the Depress. Ibid, 451.

$$
\begin{aligned}
& { }^{67} \text { Craig and Gilbert, The Diplomats, 4-5. } \\
& { }^{6}{ }^{8} \text { Ibid, } 6 .
\end{aligned}
$$


Chapter III: A Case Study: Ambassador Frederic Mosley Sackett's Assignment to Germany

${ }^{1}$ Arnold Offner, The Origins of the Second World War: American Foreign Policy and World Politics 1917-1941 (New York, 1975), 50; also by Arnold Offner, American Appeasement, United States Foreign Policy and Germany 1933-1938 (Cambridge, 1969), 10-12; and American Diplomacy and Germany, 1933-1938 (unpublished dissertation, Indiana Univ., 1964), 17 .

${ }^{2}$ Graham H. Stuart, The Department of State: A History of its Organization, Procedure and Personnel (New York, 1949), 298 .

${ }^{3}$ Edward Bennett, Germany and the Diplomacy of the Financial Crisis, 1931 (Cambridge, 1962), 31.

${ }^{4}$ For a more specific look at Ambassador Sackett's role in issues dealing with American economic relationships see Bernard V. Burke, "American Economic Diplomacy and the Weimar Republic," Mid-America, vol. 54, No. 4 (October, 1974), 211-233.

${ }^{5}$ William E. Leuchtenburg, The Perils of Prosperity, 1914-32 (Chicago, 1958), 41, 96- $\overline{97}$.

${ }^{6}$ Robert H. Ferrel1, Peace in Their Time - - The Origins of the Kellogg-Briand Pact (New York, 1952), 13-26. Among the most significant cited by Ferrell, were peace organizations supported by Andrew Carnegie, especially his Endowment for International Peace.

${ }^{7}$ Louisville Courier Journal, Sept. 26, 1924.

${ }^{8}$ Louisville Herald Post, Aug. 4, 1924; Nov. 4, 1924 ; March 4,1925 .

${ }^{9}$ Congressional Record, 69 Congress, Special Session, 42 (March 9, 1925); 70 Congress, 1 Session, 481 (Dec. 12, 1927); 71 Congress, 1 Session, 246 (April 22, 1929). Other minor committee assignments included Agriculture and Forestry, Executive Department Expenditures, and Military Affairs. Sackett, not entirely happy with his treatment on the Finance Committee, complained to Secretary of State Stimson of not getting information about matters spending before the committee from its leaders; Papers of Henry Lewis Stimson, Yale University Library, New Haven, Conn. (microfilm deposited in the Portland State University Library), hereafter cited as Stimson Papers, July 2, 1929, reel 164, 100-101. 
${ }^{1}{ }^{0}$ Congressional Record, 69 Congress, 1 Session, 2430 (January 20, 1926), 6836-37 (April 5, 1926), 11262 (June 15, 1926); 70 Congress, 1 Session, 3139 (February 17, 1928), 3153-3154 (February 17, 1928), 3094 (February 16, 1928), 6849-6862 (Spril 20, 1928). See also New York Times, April $21,1928,4: 3$.

${ }^{11}$ New York Times, May 16, 1929, $30: 8$; May 24, 1929, $26: 4$, May 26, 192 $\overline{9}$, II $, 20: 2$; May 29, 2929, 24:8. The Times reported the sackett amendment was "voted down with a laugh: as one Senator moved to exclude from the census "all persons who had violated the dry laws:" ibid.

${ }^{12}$ Herbert Hoover, The Memoirs of Herbert Hoover, The Cabinent and the Presidency 1920-1933 (New York, 1952), vol. 2, 191.

\section{${ }^{13}$ New York Times, August 5, 1928, II, 12:13; Glenn} Finch "The Election of United States Senators in Kentucky: The Cooper Period," The Filson Club History Quarterly, Vol 46, No. 2 (April, 1972) 173.

$1{ }^{4}$ New York Times, Aug. 5, 1928, II, $12: 13$; Sept. 28, 1928, 3:1; Nov. 5, 1929; Hoover was the first Republican presidential candidate to win a majority in Kentucky, taking 59 percent of the vote in 1928. Partisan percentages in 1928 were nearly equal inside and outside the four most urban Kentucky counties, however, by 1932 the drought and depression had taken a severe toll throughout the farming, mining and industrial centers and Franklin Roosevelt was given Hoover's 59 percent of the vote in what was "the most dramatic shift in the state's voting behavior since 1872." Malcolm E. Jewell and Everett W. Cunningham, Kentucky Politics (Lexington, 1968), 6-7.

${ }^{15}$ Louisville Herald Post, Oct. 9, 1924; Finch, "The Election of United States Senators in Kentucky: The Cooper Period," 173.

${ }^{16}$ Louisville Courier Journal, Oct. 10, 1929.

${ }^{17}$ Glenn Finch, "The Election of United States Senators in Kentucky: The Beckman Period," The Filson Club History Quarterly, vol. 44, No. 1, (Jan., 1970), 47.

${ }^{18}$ Hoover, Memoirs, II, 335; Two well known Washington commentators noted the "mediocrity and partisanship" displayed in many of Hoover's appointments: "His record is unsurpassed ..." They also cited Ambassador Sackett as "a machine politican who dared not face a reelection contest in Kentucky"; Robert $\mathrm{S}$. Allen and Drew Pearson, Washington Merry-Go-Round (New York, 1931), 66. 
19 Frederic M. Sackett Papers, Filson Club, Louisville, Kentucky hereafter cited as Sackett Papers, Sackett to Mrs. Bessie Hazard, Dec. 31, 1929.

${ }^{20}$ Papers of Herbert Hoover, Hoover Presidential Library, West Branch, Iowa, Presidential Papers -- Foreign Affairs, hereafter cited as Hoover Library PPFA, Kellogg to Hoover, Oct. 12, 1929; Robinson to Lawrence Richey (secretary to the President) Dec. 16, 1929; Morris reference fontained in Sackett Papers, Filson Club, Louisville. PPFA.

$$
{ }^{21} \text { Castle to Hoover, Jan. 21, 1929, Hoover Library, }
$$

${ }^{2}$ Papers of William R. Castle, Hoover Library, hereafter cited as Castle Papers, Gilbert to Castle, May 28, 1927; Jacob Gould Schurman Papers, Olin Research Library, Cornell University, Ithica, New York; Schurman's criticism was mainly directed to the way American loans were being handled. He was critical of Gilbert for being overly critical of Germany. Schurman said the loans were being used for constructive purposes and not for extravagances as Parker alleged. New York Times, Nov. 26, 1927, 12:7; United Press International dispatch, Nov. 26, 1927; Koelnische Zeitung, Nov. 27, 1927; Berlin Boerson Zeitung, Nov. 26, 1927; Lokalanzeiger, Nov. 26, 1927.

${ }^{2}{ }^{3}$ Castle to Schurman, Jan., 1928, Castle Papers, Hoover Library PPFA.

${ }^{24}$ Poole to Castle, June 6, 1929. Castle Papers, Hoover Library.

${ }^{25}$ Castle to Hoover, Jan. 21, 1929. Ibid.

${ }^{26}$ Ibid. Castle suggested Senator Walter Edge as a replacement for Schurman as he felt he could do a better job in Berlin than in Paris.

${ }^{27}$ New York Times Dec. 30, 1929, $21: 4$.

${ }^{28}$ Ibid; Papers of the Department of State, deposited in the National Archives, decimal file 123, Sackett F.M.l 19, hereafter cited by decimal file number, Schurman to State Department, Jan. 7, 1930.

${ }^{29} \mathrm{New}$ York Times, Dec. 31, 1929, 9:1.

${ }^{30} \mathrm{Ibid}$; Schurman to State Department, Jan. 7, 1930, 123, Sackett F.M./19.

${ }^{31}$ New York Times, Dec. 31, 1929, $18: 1$. 
${ }^{32}$ Ibid.

${ }^{3}{ }^{3}$ bid, $21: 4$.

${ }^{34}$ Ibid, Dec. 31, 1929, 9:1.

${ }^{35}$ Associated Press, Dec. 28, 1929, Sackett Papers, Filson Club, Louisville; Louisville Herald Post, Dec. 29, 30,1929 .

${ }^{36}$ Ibid; Louisville Courier Journal, Dec. 30, 1929.

${ }^{37}$ Louisville Herald Post, Dec. 29, 1929.

${ }^{38}$ Louisville Courier Journal, Dec. 30, 1929.

${ }^{39}$ Louisville Courier Journal, Jan. 3, 1930; Louisville Herald Post, Jan. 9, 1930.

${ }^{40}$ Louisville Courier Journal, Jan. 3, 1930; Louisville Times, Jan. 6, 1930 .

${ }^{41}$ New York Times, Jan. 2, 1930, 24:2.

${ }^{42}$ Chilton, et al to Hoover (telegram) Jan. 7, 1930, Hoover Library, PPFA -- Diplomats - Sackett FM.

${ }^{3}$ Louisville Courier Journal, January 3, 1930; New York Times, Jan. 5, 1930, 2:1 and Jan. 7, 1930, 55:4. Questions were also raised concerning the status of state patronage positions whose holders and applicants would be left in doubt once the Robsion faction gained Sackett's Senate seat; refer Louisville Times, Jan. 9, 1930 and Louisville Courier Journal, Jan. 10, 1930.

${ }^{44}$ Congressional Record, 71 Congress, 2 Session, 12881289 (January 9, 1930); New York Times, Jan. 10, 1930, 14: 4-5.

${ }^{45}$ Congressional Record, op. cit.; Copeland's brief and simple three paragraph tribute to sackett in the Congressaional Record is compared with over three-fourths of a page contributed by Copeland and two other senators (Republican and Democrat) for Senator Walter Edge when he was appointed ambassador to France; refer to Congressional Record 71 Congress, 1 Session, 5874-75, (Nov. 21, 1929).

${ }^{46}$ Cotton to Sackett, Jan. 14, 1930, decimal file 123, Sackett FM/10; New York Times Jan. 23, 1930, 14:2.

${ }^{47}$ Outlook, Jan. 22, 1930. 
${ }^{48}$ Ibid.

${ }^{49}$ Papers of Dewitt C. Poole, University of Wisconsin, Madison, Wis., Poole to Stimson, Feb. 15, 1930.

${ }^{50}$ Cotton to Poole, Jan. 3, 1930; Castle to Poole, Dec. 21, 1929, Poole Papers, Madison.

${ }^{51}$ Papers of John Cooper Wiley, Franklin Delano Roosevelt Library, Hyde Park, New York, Poole to Wiley, Jan. 23, 1930 . Madison.

${ }^{52}$ Wiley to Laird S. Goldsborough, Feb. 19, 1930.

${ }^{5} \mathrm{~W}$. deHaas to Poole, March 3, 1930, Poole Papers,

${ }^{54}$ Marion H. McVitty to Bernard V. Burke, July, 1966, in the possession of Burke, Portland State University. FM/ 29 .

${ }^{5}$ Wiley to State Dept., Feb. 7, 1930, 123, Sackett

${ }^{56}$ New York Times, Feb. 7, 1930, 6:7; In that same issue the Times editorialized on Sackett's captivation of the German press especially with his soft voice, his courtesy, and his habit of saying "suh." "It is true that Mr. Sackett comes from the South, that his voice is soft and that his manner is courteous. He also pronounces 'sir' without a hard ' $r$ '. But this pronounciation is quite as typical of his native Rhode Island -- where he lived until he reached maturity -- as of Kentucky. And soft voices and courtesy are found as commonly behind the colonial doors of Providence, Boston, Portland and Hartford, as behind those of Louisville. These are well known facts," stated the Times. "But they won't affect the legend." Ibid, 20:5.

${ }^{5}$ Ibid, Feb. 13, 1930, 7:2.

${ }^{58}$ Burke, "American Economic Diplomacy and the Weimar Republic", 222-223; Sackett to Cotton (confidential), March $26,1930,862.51 / 2853$.

${ }^{59}$ Congressional Record, 71 Congress, 2 Session, 71077109 (April 16, 1930).

${ }^{6}$ Ibid. Sackett later restated before the Chamber his view for enlarged foreign markets for American exports as the depression deepened; New York Times, Dec. 26, 1931, 4:3.

${ }^{61}$ Ibid, March 17, 1930, $22: 2$; Earlier, in February, the acting Democratic floor leader in the Senate, Thomas 
Walsh, expressed thoughts that the tariff issue would ironically catch up to Sackett in Germany. Sackett had voted for high tariffs on products from Europe while in the Senate but was now in the "anomalous position" in protesting to Germany against a retaliatory tariff. "It would seem in this situation," Walsh stated, "that in asking Ambassador Edge and Ambassador Sackett to protest to the French and German Governments against retaliatory tariffs to be levied as reprisals for our own 'prohibitive' duties on their chief: articles of export, the President has forced his Ambassadors into the position of supporting prohibitive tariffs at home and low tariffs abroad." Ibid, Feb. 3, 1930, 9:3; see also June 12, 1930, 24:1.

${ }^{62}$ New York Times, June 18, 1930; Time, June 30, 1930, 17-18; Literary Digest, July 5, 1930, vol. 106, No. 1; Nation, July 2, 1930, vol. 131, No. 3391, 3; see also Forrest McDonald, Insull, (Chicago, 1962) and M. L. Ramsey, Pyramids of Power (New York, 1937).

${ }^{6}{ }^{3}$ New York Times, June 18, 1930, 16:3.

${ }^{6}{ }^{4} \mathrm{Ib} i d$, June 19, 1930, 19:2, 19:3, $24: 6$; June 20, 1930, $8: 1$; Louisville Courier Journal and Louisville Herald Post, Nov. 1, 1929.

${ }^{6}$ New York Times, Sept. 21, 1930, 8:1; A further example of Ambassador Sackett's "charm and methodology in handling the press was noted by the Times when he disembarked in New York: "When Mr. Sackett was asked about rumors of war from Europe he smiled and replied that it required considerable money to start a war these days."

${ }^{6}$ Papers of Nicholas Murray Butler, Columbia University, New York, Sackett to Butler, Sept. 29, 1930.

${ }^{6} \mathrm{McVitty}$ to Burke, July, 1966.

${ }^{6}{ }^{8} \mathrm{New}$ York Times, Sept. 25, 1930, 36:5.

${ }^{69}$ Herbert Hoover, The Memoirs of Herbert Hoover, The Great Depression, 1929-1941 (New York, 1952), III, 38 .

${ }^{70} \mathrm{Miscle}$ untitled press clippings, Jan. 24, 1931, Sackett Papers, Filson Club, Louisville.

${ }^{71}$ Hoover, Memoirs, II I, 64-65.

${ }^{72}$ Ray L. Wilbur, The Hoover Policies (New York, 1937), 409 .

${ }^{73}$ New York Times, April 18, 1931, 9:4. 
${ }^{74}$ Ibid, May 7, 8, 10, 15, 1931 and June 14, 1931.

${ }^{75}$ Bennett, Financial Crisis, 31-33; Eric Eyck, A History of the Weimar Republic (2 vols. Cambridge, Mass., 1963, translated by Harlan P. Hanson and Robert G. $L$. Waite), II, 314.

${ }^{76}$ Sackett to Hoover, Dec. 27, 1930, Hoover Library PPFA - Diplomats, Sackett F.M.

${ }^{7}$ Ibid.

${ }^{78}$ Bennett, Financial Crisis, 35, 37; Hoover to Sackett, Jan. 12, 1931, Hoover Library, PPFA.

${ }^{79}$ Burke, "American Economic Diplomacy and the Weimar Republic," 227-233; and Bennett, Financial Crisis, 38-39; both works include detailed accounts of attempts by the American Embassy staff in Berlin to draw officianl American recongition of the financial and political difficulties facing the Brüning Government between January and May, 1931.

${ }^{80}$ Bennett, Financial Crisis, 40-41, 53-81; Hoover, Memoirs, III, 62 .

${ }^{81}$ Bennett, Financial Crisis, 113-114. Bennett argues that, according to Castle, "Hoover had been watching developments in Europe even before Sackett reported to him on May 6." Ibid, 115; Henry L. Stimson and McGeorge Bundy, On Active Service in Peace and War (New YOrk, 1947), 204-205.

${ }^{82}$ Bennett, Financial Crisis, 115 .

${ }^{8}$ Burke, "American Economic Diplomacy and the Weimar Republic," 231-232.

${ }^{8}$ Diaries of Henry Lewis Stimson, Yale University Library, New Haven, Conn. (microfilm deposited in Portland State University Library), May 4, 1931, reel 3, vol. XVI, 46-47, hereafter cited as Stimson Diary; see also Bennett, Financial Crisis, 88. It should be noted that, while the ambassador is responsible for reports coming from his embassy, most were drafted by the staff, in this case by George Gordon.

${ }^{8}{ }^{5}$ William Starr Myers and Walter Newton, The Hoover Administration - - A Documented Narrative (New York, 1936), 83; Hoover, Memoirs, III, 64-65. While Myers and most other contemporaries of Hoover place this meeting on May 6, Hoover states it happened May 7, 1931. Ibid, III, 64; see also Theodore G. Joslin, Hoover Off the Record (Garden City, N.Y., 1934), 87-89; Joslin, secretary to President Hoover, implies 
Sackett's visit to the United States in May, 1931, was disguised as a "vacation" so as not to arouse publicity; and although Sackett's original purpose was to go on home leave, little actual publicity was given Sackett's White House visit. Ibid,ii; Brüning did not believe that sackett was convinced by the communist scare theory as, not only had the threat of Bolshevism "lost its edge" since the post World War I years, but also Sackett "evoked a skeptical reaction" in his face when the Chancellor raised the subject; see. Heinrich Brüning, Memoiren, 1918-1934 (Stuttgart, 1970) 223-224.

${ }^{86}$ Herbert Hoover Moratorium Diary, Herbert Hoover (PPFA) May 6, 1931; hereafter cited as Moratorium Diary; Myers and Newton, The Hoover Administration, 82-83.

${ }^{8}$ Mark Sullivan, "President Hoover and the World Depression" Saturday Evening Post, vol. 205, no. 37, March $11,1933,1$; Moratorium Diary, May 6, 1931; Myers and Newton, The Hoover Administration, 83; Bennett, Financial Crisis, 23, 136-137; Charles Dawes mentioned in his journal on Feb. 11, 1924, the need for a moratorium of reparations payments but such a plan would have to be mindful of public opinion and that long run "reasonable assurance" of adequate reparations would have to be given to the allies. On February 19, 1924, while in Paris, Dawes noted: "Taking the maximum of what we must provide for in the way of a foreign loan, banking capital and a moratorium, it seems so small as compared with the benefits to be derived from it and the catastrophe to economic Europe if it is not provided, that failure [to extend American aid] seems inconceivable." See Charles G. Dawes, A Journal of Reparations (Londong, 1939), 100-101, 108. 6,1931 .

${ }^{8}{ }^{8}$ Hoover, Memoirs, III, 64-65; Moratorium Diary, May

${ }^{89}$ Ibid, May 7, 1931; Sullivan, "President Hoover and the World Depression", March 11, 1933,4; Castle to Hoover, June 1, 1931, Hoover Library PPFA-Financial; see also economic reports for May-June, 1931 in Papers of the Department of State, National Archives, Washington, D.C., Decimal File 462.00/R296, hereafter cited by decimal file number.

${ }^{90}$ Myers and Newton, The Hoover Administration, 83, 88;

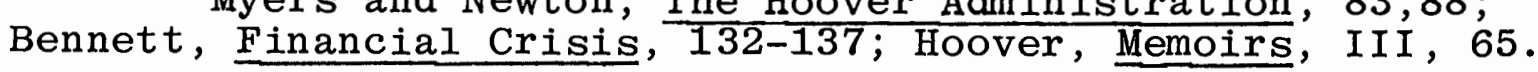

${ }^{91}$ Hoover, Memoirs, III, 67-68; Moratorium Diary, May $11,13,1931$.

${ }^{2}$ Myers and Newton, The Hoover Administration, 87; Moratorium Diary, June 2, 1931; Bennett, Financial Crisis, 
135-137; Stimson Diary, June 2, 1931, ree1 3, XVI, 120-121.

${ }^{9}$ Department of State, Papers Relat1ng to the Foreign Relations of the United States: 1931, 3 vols., Washington 1946, Gordon to Stimson, June 3, 1931, I, 4, hereafter cited as FRUS; Gordon to Stimson, June 2, 1931 and Thomas M. Lamont to Hoover, June 5, 1931, Hoover Library, PPFLFinancial; Bennett, Financial Crisis, 138.

${ }^{94}$ New York Times, June 4, 1931, $7: 3$.

${ }^{9}$ Ibid; Moratorium Diary, June 5, 1931; Bennett, Financial Crisis, 139.

${ }^{96}$ Robert H. Ferrell, "Henry L. Stimson" in Robert H. Ferrell (ed.) The American Secretaries of State and Their Diplomacy (New York, 1963), XI, 209-212; Stimson and Bund.y, On Active Service, 204; Hoover, Memoirs, III, 68-71; Bennett, Financial Crisis, 161-165.

${ }^{9}{ }^{7}$ New York Times, June 10, 1931, $2: 4$ and June 11, 1931, 8:5; Bennett, Financial Crisis, 141-142.

${ }^{98}$ New York Times, June 11, 1931, 8:5; Sullivan, "President Hoover and the World Depression" Saturday Evening Post, March 11, 1933, 5; Gordon to Stimson, June 8, 1931, FRUS, 1931 , I , 9-11.

${ }^{9}{ }^{9} \mathrm{New}$ York Times, June 11, 1931, 8:5; Meyers and Newton, The Hoover Administration, 89.

100 Bennett, Financial Crisis, 142; Stimson Diary, June 13, 1931, reel 3, XVI, 164-165; Papers of Henry Lewis Stimson, Yale University, New Haven, Conn. (microfilm deposited in Portland State University Library), Feis to Stimson, June 19, 1931, reel 81, no. 548 .

$1{ }^{1}{ }^{1}$ Stimson to Hoover, June 13, 1931, Hoover Library, PPFL-Financial; Moratorium Diary, May 26-29, 1931; Sullivan, "President Hoover and the World Depression" Saturday Evening Post, March 11, 1933, 28; Pierre de L. Boal to Walter H. Newton, June 17, 1931, Hoover Library, PPFL-Financial provides a good example of the gloomy political and financial reports about Germany fed to Hoover by the State Department.

102 Moratorium Diary, June 18, 1931.

$10{ }^{3}$ Hoover, Memoirs, III, 69-72; Stimson and Bundy, On Active Service, 204-206; Bennett, Financial Crisis, 175 ; Myers and Newton, The Hoover Administration, 99; Robert $\mathrm{H}$. Ferrell, American Diplomacy in the Great Depression (New York, 1957), 108. Hoover's secretary, Theodore Joslin, 
wote that the transatlantic telephone enabled the President personally to relay instructions to Sackett and Edge and to discuss issues and get their points of view; see Joslin, Hoover off the Record, 108-111. After the moratorium was announced, Sackett, who did not trust the telephone, told of his use of American slang in the transatlantic conversations as a "safe method of guarding against the possibility of being understood by any listener;" see New York Times, July 8, 1931, 19:2; Ferrell, American Diplomacy, 114.

104 Bennett, Financial Crisis, 146, 155, 161-162; Stimson Diary, June 20, 1931, reel 3, XVI, 196.

105 Bennett, Financial Crisis, 163; Hoover, Memoirs, III, 68-69; Joslin, Hoover Off the Record, 99; Myers and Newton, The Hoover Administration, 90-91.

${ }^{106}$ Stimson to Sackett, June 20, 1931, FRUS, 1931, I, 32-33; Memorandum of Transatlantic Telephone Conversation betwen Ramsey MacDonald and Stimson, June 19, 1931, Ibid, 30 .

$10{ }^{7}$ Sackett to Stimson, June 20, 1931, Ibid, 35; Bennett, Financial Crisis, 163; Eyck, The Weimar Republic, II, 315 .

108 Stimson to Sackett, June 20, 1931, FRUS, 1931, I, 33; Stimson to Sackett, June 21, 1931, Ibid, 37; Bennett, Financial Crisis, 163-164; Sackett to Stimson, June 22, 1931, FRUS, 1931, I, 37-38.

$1{ }^{09}$ Sackett to Stimson, June 24, 1931, FRUS, 1931, I, 39-42; The New York Times was perhaps not totally fooled by Sackett's official silence nor did they seem to believe the letter was an impromptu effort sent at German initiation. The Times speculated about the oddity of timing of the letter, see New York Times, June 22, 1931, 1:8, 15:1. The Hoover Adninistration did not release the text of the Hindenburg letter of June 20, 1931 until the following July 21 and it was published by the Associated Press without comment; Ibid, July 21, 1931, 13:4.

11 James Thayer Gerould, "The Hoover Debt Settlement" Current History, August, 1931, 641-645; Sullivan, "President Hoover and the World Depression," Saturday Evening Post; March 11, 1933, 28; Ferrel1, American Diplomacy, 118; Meyers and Newton, The Hoover Administration, 95.

111 Hoover, Memoirs, III, 71-72; Gerould, "The Hoover Debt Settlement," Current History, August, 1931, 644; Bennett, Financial Crisis, 189-196; Sackett to Castle, FRUS, 1931, I, 131-132. 
${ }^{112}$ Ibid, July 2, 1931, 1:2.

$1{ }^{3}$ Edge to Stimson, June 30, 1931, Hoover Library, PPFL-Foreign Affairs; Stimson to Sackett, June 22, 1931 , FRUS, 1931, I, 49-50; Bennett, Financial Crisis, 176-177.

114 Sackett to Stimson, June 23, 1931, FRUS, 1931, I, 50-51; Bennett, Financial Crisis, 180.

${ }^{115}$ Stimson to William R. Castle and Ogden Mills, June 28, 1931, 462.00/R296/4174; Bennett, Financial Crisis, 182183; Stimson to Castle, June 30, 1931, 462.00/R296/4220; Stimson agreed to the proposal to limit battleship construction but felt, for appearances at least, this issue should be tied to disarmament, "above political questions..." Ibid; Castle to Sackett, June 27, 1931, FRUS, 1931, I, 84-85.

${ }^{116} \mathrm{Ibid}$. Sackett to CAstle, June 28, 1931, FRUS, 1931, I, 91-93.

117 Edge to Castle, June 28, 1931, FRUS, 1931, I, 96; Memorandum by the Acting Secretary of State (Castle) of a Transatlantic Telephone Conversation to the Ambassador in Berlin (Sackett), June 29, 1931, Ibid, 97-98; Bennett, Financial Crisis, 184, 195; Castle's point was that the United States traditionally sought to stay clear of political questions at least officially. Somehow, disarmament was not always considered a political quesiton. While the American people were mostly supportive of Hoover's moratorium proposal, "such enthusiastic support would quickly wear off should they get the idea Germany was using the saved money to build a new battleship." See Memorandum by the Acting Secretary (Castle) of Conversation with the German Chargé (Leitner), June 29, 1931, FRUS, 1931, I, 98.

118 Bennett, Financial Crisis, 185-186, 191-196; Castle to Stimson, June 30, 1931, 462.00/R296/4220; Castle to Sackett, June 30, 1931 and Edge to Stimson, June 30, 1931, FRUS, 1931, I , 105-108.

${ }^{119}$ Sackett to Castle, June 30, 1931, Ibid, 112; Memorandum by Acting Secretary of State (Castle) to Telephone Conversation with Ambassador in Berlin (Sackett), July 1 , 1931, Ibid, 109-110.

${ }^{12}{ }^{\circ}$ Castle to Sackett, July 2, 1931, Ibid, 129; Bennett, Financial Crisis, 186, 190; Eyck, Weimar Republic, II, 350392 ; Sackett to Castle, July 2, 1931, I, 130-131.

${ }^{121}$ Sackett to Castle, July 3, 1931, Ibid, 132; Bennett, Financial Crisis, 188, 190; With regard to a German "volun- 
tary" concession concerning the dropping of a proposed Customs Union with Austria, Sackett never received direct authority from Washington to pursue this issue with Brüning. He had hoped the British would take up the subject as it was deemed a "political issue" to be avoided according to American foreign policy tradition. Regardless of the outward anticoncession stance of the German Government, the financial difficulties of the Kreditanstalt forced the Brüning administration to ultimately reject the Customs Union plian. Ibid, 199-202.

$12{ }^{2}$ Statement by President Hoover, July 6, 1931, FRUS, 1931, I, 163; Hoover, Memoirs, III, 72-73; Myers and Newton, The Hoover Administration, 98; Bennett, Financial Crisis, 201, 220; Ferre11, American Diplomacy, 118.

$12{ }^{3}$ Sackett to Castle, Ju1y 6, 1931, 462.00/R296/4290.

124 Myers and Newton, The Hoover Administration, 97-98, 100; Bennett, Financial Crisis, 220, 222-223, 232-233. 4398 .

${ }^{125}$ Sackett to Stimson, Ju1y 11, 1931, 462.00/R296/

$1{ }^{26}$ Castle to Sackett, July 11,1931 , FRUS, 1931, I, 250-251; Stimson Diary, July 26, 1931, reel 3, XVII, 146, and Stimson's Memorandum to the President from the Secretary of State, August 11, 1931, FRUS, 1931, I, 321; Meyers and Newton, The Hoover Administration, 100; Hoover, Memoirs, III, 72-75. Wall street bankers were even more reluctant to tackle the latest financial problems in Germany. Thomas Lamont of J. P. Morgan and Company stated the Germans should change their attitude and take internal measures to halt the flight of money from their banks. He added the idea that America would save Germany should be dispelled. Germans should do more to "stand on their own feet," he stated; Lamont to Martin Egan, July 9, 1931, Hoover Library, PPFLFinancial. 251-254.

${ }^{12}{ }^{7}$ Sackett to Castle, July 12, 1931, FRUS, 1931, I,

$1{ }^{28}$ Meyers and Newton, The Hoover Administration, 100101 ; Bennett, Financial Crisis, 234; Bennett notes the significance of Germany's internal moratorium: "It was during this period that the German presidential dictatorship passed the point of no return. Efforts to win popular support through foreign policy had failed, and instead, foreign policy itself had precipitated a financial upheaval. The closing of the banks and the effort to check foreign exchange withdrawals entailed the issuance of a whole series of measures and decrees, 'which,' as [British Ambassador to Germany 
Sir Horace] Rumbold reported, 'have brought business to a standstill, have interfered with liberty to travel, practically destroyed the freedom of the press and have set up a sort of inquisition into people's private affairs.' Ibid, 237.

$1{ }^{29}$ Stimson Diary, July 15, 1931, reel 3, XVII, 38-39, 42-43; Memorandum by the Secretary of State (Stimson) on a Telephone Conversation with the Ambassador in Berlin (Sackett) and President Hoover, July 15, 1931, FRUS, 1931, I, 263; Sackett to Stimson, July 18, 1931, 462.00/R296/4593.

$1{ }^{30}$ Sackett to Castle, July 19, 1931, FRUS, 1931, I, 282-283; Sackett to Stimson, July 21, 1931, 462.00/R196/4639; Sackett maintained the Germans would still be unyielding on the battleship controversy but hoped it

inviting Germany to join the Three Power Naval Disarmament pact. By doing so, "the threats which other countries feel are implied in [Germany's] naval construction could be decidedly toned down and German public opinion so satisfied that the Government could accept." Ibid; Castle to Sackett, July 24, 1932, FRUS, 1931, I, 551-552; Bennett, Financial Crisis, 295-304.

${ }^{131}$ Meyers and Newton, The Hoover Administration, 101105; Hoover noted his belief that most of Europe, and especially Germany, had paid the reparations installments and supported their budget deficits from borrowed money. Learning this, and recognizing the inter-relatedness of the foreign economies to America's own, Hoover said, "I don't know that I have ever received a worse shock. The haunting prospect of wholesale bank failures and the necessity of saying not a word to the American people as to the cause and the danger, lest I precipitate runs on our banks, left me little sleep. The situation was no longer one of helping foreign countries to the indirect benefit of everybody. It was now a question of saving ourselves." Hoover, Memoirs, III, 74-75; Bennett, Financial Crisis, 274-279, 305.

$1{ }^{32}$ Stimson to the Chargé d'Affaires in Paris, Nov. 18, 1931, 462.00/R296A/30A; Sackett to Stimson, Oct. 3, 1931, FRUS, 1931 , I , 326-331.

133 Ibid; Brüning also pressed for an overseas colony to relocate a surplus German population and stave-off growing unemployment. He hoped the United States would push this suggestion on behalf of Germany; Ibid; Sackett to Hoover, Oct. 31, 1931, Hoover Library, PPFL-Diplomats, Sackett, F.M.

134 Ibid; Bennett, Financial Crisis, 307-309. 
$1{ }^{5}$ Stimson and Bundy, On Active Service, 268-272; Stimson Diary, July 31, 1931 and August 27, 1931, ree1 3, XVII , 159, 178-183.

136 Papers of George S. Messersmith, University of Delaware, Dover, Messersmith to Villard, July 30, 1931.

${ }^{1}{ }^{37}$ Notes for Memoirs, Messersmith Papers, University of Delaware, Dover.

${ }^{13}{ }^{8} \mathrm{Ibid}$.

$1{ }^{39}$ New York Times, June 28, 1931, III - 3:5.

140 Ibid, June 29, 1931, 18:2; Ibid, Oct. 28, 1931, 4:6.

${ }^{141}$ Ibid, April 25, 1932, 5:3; April 26, 1932, 8:6.

142 The Providence Journal, July 2, 1931, Sackett Papers, Filson Club.

Club.

$1{ }^{43}$ Boston Herald (undated), Sackett Papers, Filson

$1{ }^{44}$ Marion H. McVitty to Bernard V. Burke, July, 1966 (private letter in the possession of Burke, Portland State University History Dept.).

$1{ }^{45}$ Eyck, Weimar Republic, II, 388; Burke, :American Economic Diplomacy and the Weimar Republic," 228.

$1{ }^{46}$ Sackett to Hoover, April 29, 1932, Hoover Library, PPFA-Diplomats.

147 Ibid.

$1{ }^{48}$ Hoover to Sackett, May 13, 1932 , Ibid.

149 New York Times, Oct. 5, 1932, 23:3.

${ }^{150}$ Ibid, October 10, 1932, 17:2.

151 Oswald Garrison Villard Correspondence, Harvard University, Cambridge, Mass. Sackett to Villard, Oct. 24, 1932 ; Stimson and Bundy, On Active Service, 282-288; New York Times, Oct. 16, 1932, 1:6; Oct. 22, 1932, 8:5.

${ }^{152} \mathrm{Ibid}$, Oct. 22, 1932, 8:5; during an appearance before the Board of Trade for German-American Commerce, Inc., the German Consul General in New York praised Sackett for his own work in Germany. The Consul stated Sackett enjoyed "unequaled admiration, respect and friendship in Germany" 
and that due to the American initiative with regard to the Hoov́er Moratorium, "Germany was saved from complete economic and financial breakdown..." Ibid.

$1{ }^{5} \mathrm{Carr}$ to Castle, Oct. 28, 1932, deeimal file 123/ Sackett F.M./149-personal file.

$154^{4}$ Stimson and Bundy, On Active Service, 289; New York Times, Nov. $12,1932,3: 4$.

${ }^{155}$ Ibid, Jan. 14, 1933, 7:5.

156 American diplomats returning from their posts after the installation of the Roosevelt Administration were not able to plead diplomatic immunity as the basis of non-payment of liquor duties for alcohol brought back with them. Among them were Ambassadors Sackett and Walter Edge from the Embassy in France returning with 400 and 900 bottles, respectively. "Secretary of Treasury Morganthau, a Democrat, saw no reason to postpone the operation of customs regulations in order to accomodate two wealthy Republican exdiplomats," according to Graham H. Stuart in American Diplomatic and Consular Practise (New York, 1952), 228-229.
$1{ }^{5}$ New York Times, March 11, 1933, 8:7.
${ }^{158}$ Ibid, March 23, 1933, 10:2.
159 Ibid.

Chapter IV: Conclusions - - Rating Ambassador Sackett

${ }^{1}$ Charles $P$. Kindleberger, The World In Depression, 1929-1939 (Berkeley, 1973), 297-298.

${ }^{2}$ Herbert Hoover, The Memoirs of Herbert Hoover; The Great Depression, 1929-1941 (New York, 1952), III, 65-67, 73,80 .

${ }^{3}$ Ibid, 78; Henry L. Stimson and. McGeorge Bundy, On Active Service In Peace and War (New York, 1947), 209, $213-$. 217.

${ }^{4}$ Selig Adler, The Isolationist Impulse -- Its Twentieth Century Reaction (New York, 1957), 128, 149 .

${ }^{5}$ Ibid, 228.

${ }^{6}$ Kindleberger, The World In Depression, 297. 
SELECTED BIBLIOGRAPHY

Primary materials*

The Boston Herald

Heinrich Brüning, Memoiren, 1918-1934, Deutsche VerlageAnstalt, Stuttgart, 1970 .

Nicholas Murray Butler Papers, Columbia University, New York.

William R. Castle Papers, Herbert Hoover Presidential Library, West Branch, Iowa.

Congressional Record

Herbert Hoover, The Memoirs of Herbert Hoover, vol. I : The Cabinent and the Presidency, 1920-1933; vol. I II : The Great Depression, 1929-1941, Macmillan Co., New York, 1952 .

Herbert Hoover Moratorium Diary, Herbert Hoover Presidential Library, West Branch, Iowa.

Herbert Hoover Presidential Papers, Herbert Hoover Presidential Library, West Branch, Iowa.

Herbert Hoover, Public Papers of the Presidents of the United States: Herbert Hoover, U: S. Government Printing Office, Washington, 1974.

Fred L. Israel (ed.), The State of the Union Messages of the Presidents, 1790-1966, vol. III, Chelsea House-Robert Hector, New York, 1966.

George F. Kennan, Memoirs, 1925-1950, Little, Brown and Company, Boston, 1967.

Louisville Courier Journal.

*Unless otherwise cited, photocopies of primary manuscript materials are in the possession of $\mathrm{Dr}$. Bernard V. Burke, Portland State University History Department. 
Louisville Providence Journal.

George Messersmith Papers, University of Delaware, Dover.

New York Times, 1928-1933.

Outlook Magazine, 1930.

Frederic Mosley Sackett Papers, Filson Club, Louisville, Kentucky.

Jacob Gould Schurman Paper, John M. Olin Research Library, Cornell University, New York.

State, Department of, Papers of the U.S. Department of State, National Archives, Washington, decimal files 462.00/R296 and 123, Sackett, FM.

State, Department of, Papers Relating to the Foreign Relations of the United States, 1931, vol. 1, U.S. Government Printing Office, Washington, 1946.

Henry Lewis Stimson Diary, Yale University, New Haven, Conn. (microfilm deposited in Portland State University Library).

Henry Lewis Stimson Papers, Yale University, New Haven, Conn. (microfilm deposited in Portland State University Library).

Henry L. Stimson and McGeorge Bundy, On Active Service In Peace and War, Harper and Brothers, Inc., New York, 1947.

Dewitt Clinton Poole Papers, University of Madison.

Oswald Garrison Correspondence, Harvard University, Cambridge, Mass.

Secondary materials

Selig Adler, The Isolationist Impulse - - Its Twentieth Century Reaction, The Free Press, New York, 1957.

Selig Adler, The Uncertain Giant, 1921-1941; American Foreign Policy Between the Wars, Macmillan Company, New York, 1965.

Robert S. Allen and Drew Pearson, Washington Merry-Go-Round, Horace-Liveright, Inc., New York, 1931. 
Thomas Bailey, The Art of Diplomacy - The American Experience, Appleton, Century, Crofts Co., New York, 1968 .

Thomas Bailey, A Diplomatic History of the United States, Appleton, Century, Crofts Co., New York, 1969.

Edward W. Bennett, Germany and the Diplomacy of the Financial Crisis, 1931, Harvard University Press, Cambridge, Mass., 1962.

Joseph Brandes, Herbert Hoover and Economic Diplomacy -Department of Commerce Policy, 1921-1928, University of Pittsburg Press, Pittsburg, Penn., 1962.

Ellis Briggs, Anatomy of Diplomacy - The Origin and Execution of American Foreign Policy, David McKay Co., Inc., New York, 1968.

Ellis Briggs, Farewell to Foggy Bottom - The Recollections of a Career Diplomat, David McKay Co., Inc., New York, 1964 .

Brookings Institute, United States Foreign Policy - Formulation and Administration, U. S. Government Printing Office, Washington, 1960.

Lee H. Burke, Ambassador at Large; Diplomat Extraordinary, Martinus Nijhoff, the Hague, 1972.

Katherine Crane, Mr. Carr of State, St. Martin's Press, New York, $1 \overline{960 .}$

William Yandell Elliot (ed.), United States Foreign Policy; Its Organization and Control, Columbia University Press, New York, 1952.

Erich Eyck, A History of the Weimar Republic, From the Locarno Conference to Hitler's Seizure of Power, vol. II, Atheneum, New York, 1970.

Robert H. Ferrell, American Diplomacy in the Great Depression; Hoover-Stimson Foreign Policy, 1929-1933, W. W. Norton and Company Inc., New York, 1957.

Robert H. Ferrell, Peace In Their Time - The Origins of the Kellogg-Briand Pact, W. W. Norton and Company, Inc., New York, 1952 .

Herbert Feis, Diplomacy of the Dollar, 1919-1939, W. W. Norton and Company, Inc., New York, 1950. 
Hugh Gibson, The Road to Foreign Policy, Doubleday, Doran and Company, Inc., Garden City, New York, 1944.

John Ensor Harr, The Professional Diplomat, Princeton University Press, Princeton, New Jersey, 1969.

Warren F. Ilchman, Professional Diplomacy in the United States, 1779-1939 - A Study in Administrative History, University of Chicago Press, Chicago, III., 1961 .

Henry M. Jackson (ed.), The Secretary of State and the Ambassador -- Jackson Subcommittee Papers on the Conduct of American Foreign Policy, Frederick Praeger Publishers, New York, 1964.

Theodore G. Joslin, Hoover off the Record, Doubleday, Dor an and Company, Inc., Garden City, N. Y., 1951.

Malcolm E. Jewell and Everett W. Cunningham, Kentucky Politics, University of Kentucky Press, Lexington, Ky., 1968 .

Charles P. Kindleberger, The World in Depression, 1929-1939, University of California Press, Berkeley, Calif., 1973.

William E. Leuchtenburg, The Perils of Prosperity, 1914-32; The University of Chicago Press, Chicago, III., 1958.

James L. McCamy, The Conduct of the New Diplomacy, Harper and Row, New York, 1964.

William Starr Myers, The Foreign Policies of Herbert Hoover, 1929-1933, Charles Scribner's Sons, New York, 1940.

William Starr Myers and Walter H. Newton, The Hoover Administration - - A Documented Narrative, Charles Scribner's Sons, New York, 1936.

Arnold Offner, American Appeasement - United States Foreign Policy and Germany, 1933-1938, Belknap Press of Harvard University Press, Cambridge, Mass., 1969.

Arnold Offner, The Origins of the Second World War: American Foreign Policy and World Politics, 19171941, Praeger Publishers, New York, 1975.

Robert E. Osgood, Ideals and Self-Interest in America's Foreign Relations, University of Chicago Press, Chicago, I11., 1953. 
Dexter Perkins, Foreign Policy and the American Spirit, (edited by Glyndon G. Van Deusen and Richard C. Wade) Cornell University, New York, 1957; Kennikat Press, Port Washington, N. Y., 1972 .

Elmer Plischke, The Conduct of American Diplomacy, D. Van Nostrand Co., Inc., New York, 1950.

Robert D. Schulzinger, "The Making of the Diplomatic Mind: The Training, Outlook and Style of United States Foreign Service Officers, 1906-1928," (unpublished dissertation) Yale University, New Haven, Conn., 1971.

Richard Snyder and Edgar S. Furniss, Jr., American Foreign Policy, Rinehart and Company, New York, 1954.

E. Wilder Spaulding, Ambassadors Ordinary and Extraordinary, Public Affairs Press, Washington, 1961.

Graham H. Stuart, American Diplomatic and Consular Practice, Appleton, Century, Crofts, Inc., New York, 1952.

Graham H. Stuart, The Department of State: A History of Its Organization, Procedure and Personnel, The Macmillan Company, New York, 1949.

Charles W. Thayer, Diplomat, Harper and Brothers, New York, 1959.

Kenneth W. Thompson, American Diplomacy and Emergent Patterns, New York University Press, New York, 1962.

Kenneth W. Thompson, Political Realism and the Crisis of World Politics - An American Approach to Foreign Policy, Princeton University Press, Princeton, New Jersey, 1960.

Frederick Van Dyne, Our Foreign Service - The ABC of American Diplomacy, The Lawyers Co-operative Publishing Co., Rochester, N. Y., 1909.

Harris Gaylord Warren, Herbert Hoover and The Great Depression, W. W. Norton and Company, Inc., 1967.

Sidney Warren, The President as World Leader, J. B. Lippincott Co., New York, 1964.

H. Bradford Westerfield, The Instruments of America's Foreign Policy, Thomas Crowell Co., New York, 1963. 
Martin Weil, A Pretty Good Club -- The Founding Fathers of the U. S. Foreign Service, W. W. Norton and Company, Inc., New York, 1978.

Ray L. Wilbur, The Hoover Policies, Charles Scribner's Son, New York, 1937.

Articles

Selig Adler, "Hoover's Foreign Policy and the New Left," in Martin Fausold and George T. Mazuzan, eds., The Hoover Presidency, State University of New York Press, Albany, 1974.

Bernard V. Burke, "American Economic Diplomacy and the Weimar Republic," Mid-America, LIV (1972), 211-233.

Robert Dallek, "Beyond Tradition: The Diplomatic Careers of W. E. Dodd and George Messersmith, 1933-1938," South Atlantic Quarterly (Spring, 1967) Vol. 60, No. 2, 233-244.

Robert H. Ferrell, "Henry L. Stimson," In American Secretaries of State and Their Diplomacy, XI, Cooper Square Publishers Inc., New York, 1963, 137-289.

Glenn Finch, "The Election of United States Senators in Kentucky: The Cooper Period," Filson Club History Quarterly, Vol. 46, No. 2 (April, 1972), 161-178.

Glenn Finch, "The Election of United States Senators in Kentucky: The Beckman Period," Filson Club History Quarterly, Vol. 44, No. 1 (January, 1970), 38-50.

Franklin Ford, "Three Observers in Berlin: Rumbold, Dodd, and Francois-Poncet," in Gordon A. Craig and.Felix Gilbert, eds., The Diplomats, 1919, 1939, Princeton, New Jersey, $195 \overline{3}$.

James Thayer Gerould, "The Hoover Debt Settlement," Current History (August, 1931), 641-645.

Mark Sullivan, "President Hoover and the World Depression," Saturday Evening Post, (March 11, 1933), Vo1. 205, No. 37.

George F. Kennan, "The Future of Our Professional Diplomacy," Foreign Affairs, (July, 1955), Vol. 33, No. 4, 566586 . 
Melvyn P. Leffler, "Political Isolationism, Economic Expansionism, Or Diplomatic Realism: American Policy Toward Western Europe, 1921-1933," in Donald Fleming and Bernard Bailyn (eds.), Perspectives In American History, VIII, Cambridge, Mass., 1974, 413-461.

Claire Booth Luce, "The Ambassadorial Issue: Professionals or Amateurs?" Foreign Affairs, Vol. 36, No. 1 (Oct.., 1957), 105-121.

Dexter Perkins, "The Department of State and American Public Opinion," in Gordon A. Craig and Felix Gilbert, eds., The Diplomats, 1919-1939, Princeton, New Jersey, 1953, 282-308.

Henry L. Stimson, "Bases of American Foreign Policy During the Past Four Years," Foreign Affairs, Vol. 11, No. 3, (April, 1933), 383-396.

Joan Hoff Wilson, "A Re-evaluation of Herbert Hoover's Foreign Policy," in Martin L. Fausold and George T. Mazuzan (eds.) The Hoover Presidency, State University of New York Press, Albany, N. Y., 1974, 164-186. 